\title{
Spatial analysis of toxic emissions in LCA: A sub-continental nested USEtox model with freshwater archetypes
}

\author{
Anna Kounina ${ }^{\mathrm{a}, \mathrm{b}, *}$, Manuele Margni ${ }^{\mathrm{b}, \mathrm{c}}$, Shanna Shaked ${ }^{\mathrm{d}}$, Cécile Bulle ${ }^{\mathrm{c}}$, Olivier Jolliet ${ }^{\mathrm{b}, \mathrm{d}}$ \\ a Ecole Polytechnique Fédérale de Lausanne, 1015 Lausanne, Switzerland \\ b Quantis, Parc scientifique EPFL, Bâtiment D, 1015 Lausanne, Switzerland \\ c CIRAIG, Polytechnique of Montréal, Chemin Polytechnique Montréal, QC, Canada \\ d University of Michigan, School of Public Health, Environmental Health Sciences, Ann Arbor, MI 48109, USA
}

\section{A R T I C L E I N F O}

\section{Article history:}

Received 8 July 2013

Accepted 10 April 2014

Available online 6 May 2014

\section{Keywords:}

Spatial differentiation

USEtox

Life Cycle Assessment

Ecotoxicity

Human toxicity

Archetypes

\begin{abstract}
A B S T R A C T
This paper develops continent-specific factors for the USEtox model and analyses the accuracy of different model architectures, spatial scales and archetypes in evaluating toxic impacts, with a focus on freshwater pathways. Inter-continental variation is analysed by comparing chemical fate and intake fractions between sub-continental zones of two life cycle impact assessment models: (1) the nested USEtox model parameterized with sub-continental zones and (2) the spatially differentiated IMPACTWorld model with 17 interconnected sub-continental regions. Substance residence time in water varies by up to two orders of magnitude among the 17 zones assessed with IMPACTWorld and USEtox, and intake fraction varies by up to three orders of magnitude. Despite this variation, the nested USEtox model succeeds in mimicking the results of the spatially differentiated model, with the exception of very persistent volatile pollutants that can be transported to polar regions. Intra-continental variation is analysed by comparing fate and intake fractions modelled with the a-spatial (one box) IMPACT Europe continental model vs. the spatially differentiated version of the same model. Results show that the one box model might overestimate chemical fate and characterisation factors for freshwater eco-toxicity of persistent pollutants by up to three orders of magnitude for point source emissions. Subdividing Europe into three archetypes, based on freshwater residence time (how long it takes water to reach the sea), improves the prediction of fate and intake fractions for point source emissions, bringing them within a factor five compared to the spatial model.

We demonstrated that a sub-continental nested model such as USEtox, with continent-specific parameterization complemented with freshwater archetypes, can thus represent inter- and intra-continental spatial variations, whilst minimizing model complexity.
\end{abstract}

(c) 2014 Elsevier Ltd. All rights reserved.

\section{Introduction}

Decision-making in green chemistry and chemical screening needs adapted tools to assess fate, exposure and risks of chemicals on human health and ecosystems. In a global economy, where products are manufactured and used in various continents over their life cycle, we specifically need tools able to assess and differentiate pollutants emitted on different continents and in meaningful geographical units within a continent and related potential impacts. Life Cycle Assessment (LCA) is a useful approach for such decisions, with its multimedia and multi-pathway exposure models recognized as particularly wellsuited to assess eco-toxicity and human toxicity impacts (Finnveden et al., 2009; Pennington et al., 2004; Udo de Haes et al., 2002).

\footnotetext{
* Corresponding author at: Ecole Polytechnique Fédérale de Lausanne, 1015 Lausanne, Switzerland. Tel.: +41216939195; fax: +41216939196.

E-mail address: anna.kounina@quantis-intl.com (A. Kounina).
}

USEtox is a consensus model developed within the Life Cycle Initiative led by the United Nations Environmental Program and the Society of Environmental Toxicology and Chemistry (UNEPSETAC) (Hauschild et al., 2008; Henderson et al., 2011; Rosenbaum et al., 2008, 2011). This parsimonious and transparent model can screen thousands of chemicals and is widely used, but only provides continent-generic characterisation factors and impact scores for a generic unknown continent. Since human and eco-toxicity occur as regional or local impacts (Potting and Hauschild, 2006; Sedlbauer et al., 2007), recently developed multimedia and multi-pathway models are spatially differentiated in order to provide different impact scores for each regional zone. Spatial differentiation reduces model uncertainty and improves accuracy, precision and confidence in LCA results (Manneh et al., 2010; Potting and Hauschild, 2006; Sleeswijk and Heijungs, 2010). There is therefore a need to customize USEtox for different specific regions of the world in addition to the existing generic continent. 
Inter-continental variation has been investigated using a nested parameterization of the IMPACT 2002 model (Rochat et al., 2004), with continent-specific boxes nested within the world. The Australian adaptation of the USES-LCA 2.0 model has been similarly investigated by Lundie et al. (2007). Rochat et al. (2004) found a factor 1.7 to 25 variation in human health impacts among continents. The variation is especially high for short-lived pollutants, e.g., the ingestion intake fraction of aldrin varies by a factor 25 between emissions in Europe and Oceania. These studies, however, do not address whether regionspecific nested models accurately capture results obtained by spatially resolved models that include advection between continents for a set of chemicals covering a wide set of physico-chemical properties. There is a need to evaluate how far this full advection modifies the assessment of fate and exposure and whether a nested individual sub-continental model is sufficient for chemical screening.

Intra-continental variation has been investigated at several resolutions, including $1 \times 1 \mathrm{~km}$ grid cells for the MAPPE Europe model (Pistocchi et al., 2010; Vizcaíno and Pistocchi, 2010), ecological zones with a continental coverage for the BETR North America model (MacLeod et al., 2004), and watershed or sub-watershed resolution for freshwater emissions in various parameterizations of the IMPACT 2002 model (Humbert et al., 2009; Manneh et al., 2010). Depending on the emission location within a given continent, intake fractions vary by 2 to 3 orders of magnitude for emissions to air (MacLeod et al., 2004) and up to 10 orders of magnitude for emissions to water (Manneh et al., 2010), highlighting the necessity of high resolution to reduce intake fraction variability.

Assuming continent-level homogeneity may therefore lead to systematic errors, spatial differentiation is necessary. The choice of spatial resolution should account for scientific needs, as well as more practical data and computational constraints (Sedlbauer et al., 2007). Dividing a region into sub-regions with specific characteristics provides one way of limiting the geographical data requirements (e.g., meteorological, population, and agricultural zones) whilst maintaining sufficient accuracy. Humbert et al. (2011) showed that intake fractions from inhalation of primary particulate matter can be modelled based on emission release height and "archetypal" environment (indoor versus outdoor; urban, rural, or remote locations) and vary by orders of magnitude among conditions considered. Several other authors have used the archetype approach to estimate human toxicity impacts from air emissions, including Hellweg et al. (2009) and Wenger et al. (2012) for indoor air and Rosenbaum et al. (2011) for urban emissions by continent. However, a similar archetypal approach has not yet been developed for related fate and exposure for water emissions. There is a need to explore the relevance of the archetype approach for emissions to freshwater compartments with various hydrological key characteristics.

This work aims to evaluate an appropriate model architecture (nested vs. spatially differentiated) and spatial resolution for the freshwater eco-toxicity and human toxicity impact categories in order to maintain environmental relevance whilst limiting model sophistication in terms of landscape data requirements. This paper primarily focuses on freshwater related pathways affecting human health and ecosystem quality by analysing pollutant fate in freshwater, as well as ecosystem and human exposure, aiming to:

1. Develop landscape parameters for USEtox to develop continentspecific boxes nested within the world.

2. Analyse the inter-continental variation of chemical fate and intake fractions among continents and examine the influence of the region(s) surrounding the considered sub-continent. For this, results from a nested USEtox model with continent-specific parameterization are compared to a fully connected model.

3. Study intra-continental variation and develop archetypes for freshwater eco-toxicity and human toxicity exposure to ingestion of freshwater and fish, as a parsimonious surrogate to higher spatial resolution.

\section{Materials and methods}

We selected IMPACTWorld (Shaked, 2011) to create and parameterize USEtox continents nested within a global box and analyse intracontinental variation on the sub-continental level. IMPACTWorld is the only global interconnected model of pollutant fate and exposure modelling atmospheric air transport, whilst the only other interconnected global model GLOBOX (Sleeswijk and Heijungs, 2010) is based on average measured wind speeds at ground level (independent of direction) in capital cities. It models media-specific concentrations and intake fractions in 17 sub-continental regions fully interconnected by advective air and freshwater flows, which offers an interesting element of comparison with nested model, but results in an increased level of complexity. The concentrations of PCB-118 in the environment and food were compared to measured empirical concentrations (2011). The comparison showed that the accuracy of IMPACTWorld in predicting environmental concentrations is generally within an order of magnitude, compared to 12 orders of magnitude of variability among impact characterisation factors among different substances (Rosenbaum et al., 2008).

We selected the IMPACT 2002 model on the watershed scale for a European resolution to analyse inter-continental variation. This model was compared and evaluated against monitored data (except for the freshwater fish ingestion pathway) (Humbert et al., 2009; Margni et al., 2004; Pennington et al., 2005). The advantage of this model is that it is resolved on a watershed scale, which corresponds to an adequate definition of flow patterns at the regional scale to study intracontinental variation for freshwater eco-toxicity and human toxicity exposure to ingestion of freshwater and fish. The water runoff data has been compiled in this model based on empirical data from the Global Runoff Data Centre (2002). Hydrological datasets are recently available at a higher resolution at $0.5^{\circ}$ (Jolliet et al., 2012; Vörösmarty et al., 2000) and $15^{\prime}$ (Lehner et al., 2006) but are not yet implemented in multimedia models.

\subsection{Parameterization of USEtox landscape data}

IMPACTWorld is a spatially differentiated multimedia model that divides the world into 17 sub-continental regions, 9 ocean regions, and 33 coastal regions (Fig. 1). The regions of the IMPACTWorld model are similar to those chosen for the Input-Output model (Fiot, 2009; Miller and Blair, 1985; Peters and Hertwich, 2007) with some key differences to (1) put less emphasis on geographical boundaries and (2) represent the best trade-off between continental or sub-continental resolution and the representation of population densities and meteorological conditions (Shaked, 2011). As in previous IMPACT versions (Pennington et al., 2005), each continental region consists of an air zone (containing an air compartment) and a terrestrial zone (containing water, soil, above-ground leaf crops, roots, and sediment), and each ocean region consists of an air zone and an ocean zone (containing surface ocean, deep ocean, and ocean sediment). Each region is characterised by environmental and demographic parameters, such as rainfall rate, vegetation fraction, and, most importantly for estimating population intake, vegetable and animal production intensity and population density.

In a first step, we developed parameterized sub-continental and continental specific landscapes in USEtox based on the 17 zones of the IMPACTWorld model (Shaked, 2011). To achieve this, we successively consider the IMPACTWorld parameterization of each subcontinent, grouping the rest of the world into the USEtox global box. Special care was taken to define advection rates between each sub-continent and the surrounding global box, based on average wind speed over the height of the continental air box (for example, the US region has an average wind speed of $7.0 \mathrm{~m} / \mathrm{s}$ over the lowest $1000 \mathrm{~m}$ of air). This advective wind speed over $1000 \mathrm{~m}$ is typically higher than the $3 \mathrm{~m} / \mathrm{s}$ used in USEtox, which is the default wind speed at $10 \mathrm{~m}$ height used to determine exchange rates between 


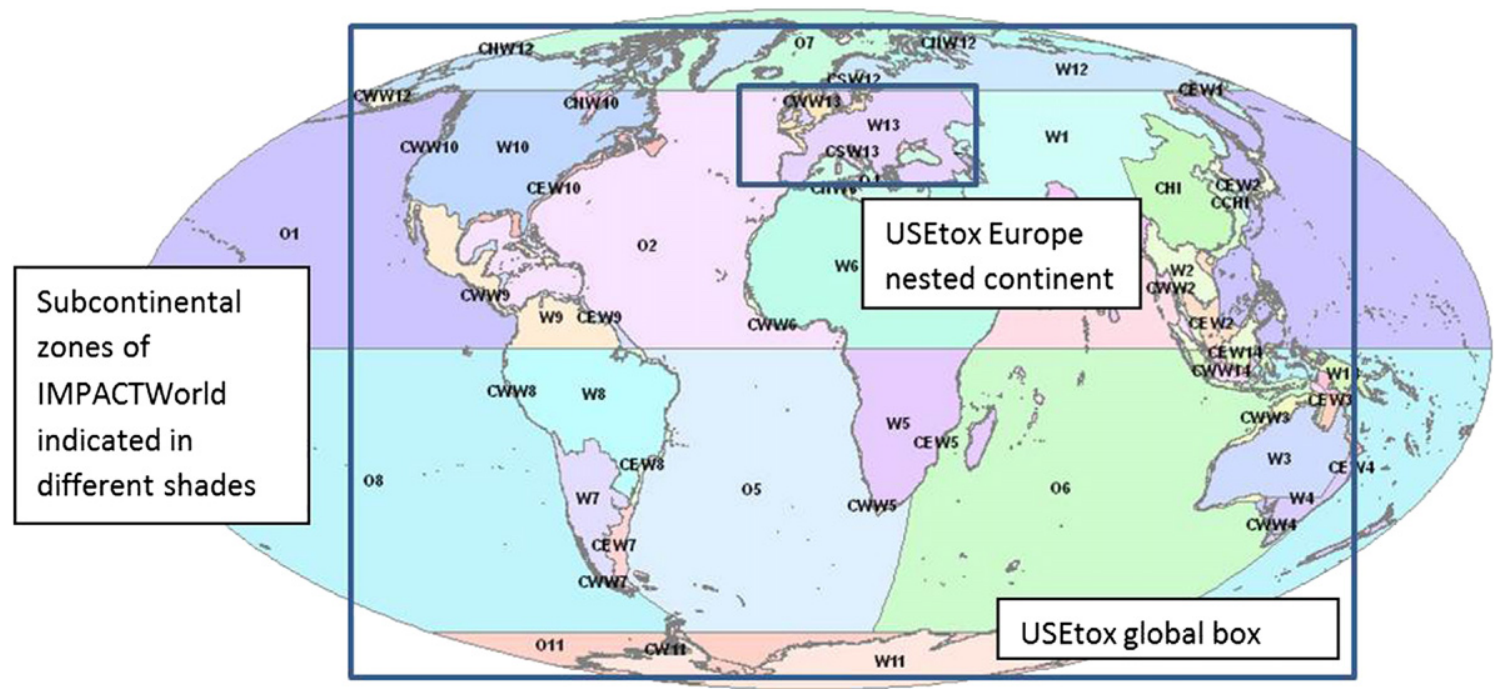

Fig. 1. Depiction of how the IMPACTWorld model (Shaked, 2011) is used to parameterize the Europe box of USEtox, nested within the global box.

air, soil and water surface compartments. In a second step, we grouped these 17 zones into 8 continental zones delimited by Humbert et al. (2011) to reduce data collection needs for LCA practitioners whilst still meeting the need of continent-specific characterisation factors for LCA studies.

Table 1 shows selected key landscape parameters of the USEtox parameterization for each of the 17 zones. The full set of parameters is provided for these sub-continental zones and for the 8 continental zones in Appendix A. The key physical parameters which influence exposure through the aquatic environment are the mean freshwater depth, which varies by a factor 15 across continents, and the freshwater residence time of water to the sea (Henderson et al., 2011; Pennington et al., 2005), which varies by a factor 83 . Freshwater residence time to the sea $\tau_{\text {sea }}$ is calculated by summing the residence time in subcontinental zone $i$ with the transfer fraction to all sub-continental zones $j$ downstream of $\mathrm{i} f_{j}$ downstream multiplied by their freshwater residence times $\tau_{j}$ as follows:

$\tau_{\text {sea } i}=\tau_{i}+\sum_{f_{j \text { downstream }}} \tau_{j}[\mathrm{~d}]$

Exposure data are based on regional populations and food production statistics from FAO (2001), and they vary by up to a factor 1850 for marine fish consumption per capita.

\subsection{Inter-continental variation and influence of surrounding regions}

Landscape parameters such as sub-continental land area, mean freshwater depth, freshwater residence time to sea, and population density influence chemical fate in environment and human intake. We first analyse the variation of fate and human exposure within each of the 17 sub-continents and thus the relevance of using a specific subcontinent rather than generic continental parameters. The analysis is performed for a set of 36 non-dissociating and non-amphiphilic organic chemicals selected from the OMNIITOX project (Margni, 2003; Margni et al., 2002). It represents well the variability of physicochemical properties of organic substances as reported in Appendix B. This set covers all relevant combinations in terms of environmental partitioning and exposure routes, overall persistence, long-range transport and feedback fraction.
In parallel, we use this chemical set to examine the influence of surrounding region(s) on the fate and exposure of emissions within the considered sub-continent. For this, results from the nested USEtox model with continent-specific parameterization are compared to the fully connected IMPACTWorld model. The 17 zones of the nested USEtox model have the same resolution and landscape parameters as those in the interconnected IMPACTWorld model. Beyond this commonality, the two models calculate fate and intake fraction differently in two key ways: (1) USEtox embeds the sub-continent in a single global box, whereas IMPACTWorld explicitly connects the sub-continental zone to specific adjacent zones, and (2) the model algorithms for exposure and particularly fate are somewhat different. The latter difference can be illustrated by the modelling of advective outflow from a subcontinental zone. It is based on river discharges out of sub-continental zones taken from external references in IMPACTWorld and on a mass balance based on precipitation, evaporation and advection in USEtox. Between these two models, we compared the fate and inhalation intake fractions, as well as ingestion intake fractions through drinking freshwater and eating fish, exposed produce (above-ground leaf crops, including fruit and cereals), unexposed produce (below-ground root crops), dairy and meat products.

\subsection{Intra-continental variation and identification of key spatial variation parameters}

Intra-continental variation was analysed on a finer resolution by comparing USEtox for Europe to the following versions of the IMPACT Europe model: the IMPACT Europe single zone model without spatial distinction (i.e., with one homogeneous compartment per environmental medium), and the IMPACT Europe spatial model accounting for spatial differentiation of 135 watersheds and land zones and 156 air zones on a $2 \times 2.5^{\circ}$ grid. Both spatial and a-spatial versions are nested into an a-spatial global zone.

This comparison was carried out first assuming uniformly distributed emissions (i.e., emissions distributed in each watershed proportionally to its land surface area). We then compared results for emissions occurring entirely in one of three selected watersheds being representative of three very different landscape characteristics: a near coast emission in Brittany, an emission into a long river (Danube) and an emission upstream of a large lake (Lake Geneva). We then analysed the interaction between chemical properties and spatially differentiated landscape 


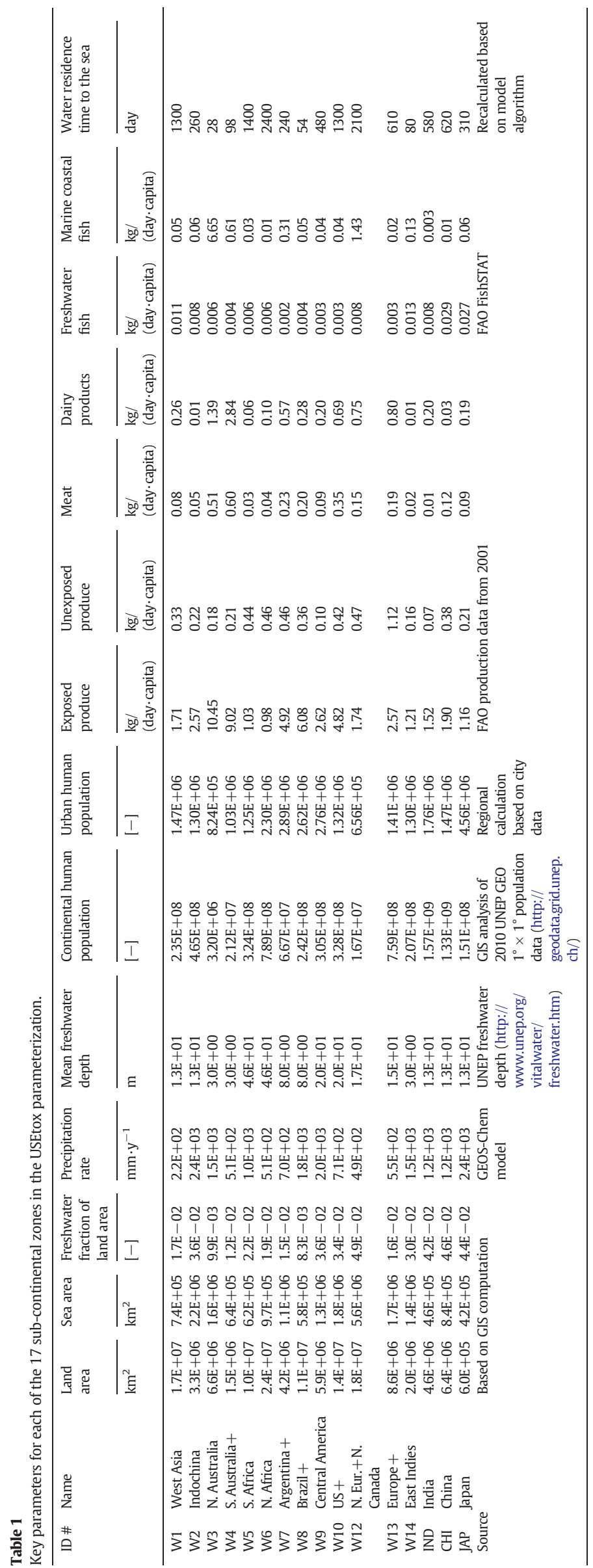

properties of each watershed to identify the key parameters influencing the fate factors.

Previous observations (Pennington et al., 2005) show that within an open system (1) the regionalization for aquatic eco-toxicity is only relevant for persistent pollutants (i.e., pollutants with a degradation rate higher than the advection rate); and (2) for these persistent pollutants, one important factor affecting fate is the freshwater residence time until reaching the landscape boundary (i.e., until the sea or any other advection into the global system). The mean freshwater depth also affects elimination rates by volatilization and sedimentation and might also play a role. Exposure factors such as the fraction of freshwater volume ingested by the population as drinking water or indirectly through fish ingestion may also influence the freshwater-mediated intake fraction. We therefore analyse the influence of water residence time, water depth and population intake rates and their autocorrelation across the 135 watersheds.

\subsection{Development of freshwater archetypes based on freshwater residence time}

Based on the identified key parameters, we ultimately developed a method to create a limited number of watershed archetypes and test how well these archetypes reflect major variations in fate and exposure across watersheds.

Due to the importance of freshwater residence time until reaching the sea (or the model boundary) found in previous work (Pennington et al., 2005), this parameter could be used in a first step as the main variable to define these archetypes. To keep the number of archetypes manageable for common practice in Life Cycle Inventory, we define three freshwater residence time archetypes, corresponding to A1) coastal zones with short freshwater residence times, A2) zones with medium freshwater residence times and $\mathrm{A} 3$ ) zones with high freshwater residence times. We define the mean residence times in each zone as $\tau_{\text {sea A1 }}, \tau_{\text {sea A2 }}$ and $\tau_{\text {sea A3 }}$ and the upper threshold residence times for zones A1 and A2 as $\tau_{12}$ and $\tau_{23}$ (upper threshold is infinite for A3). These upper thresholds were defined by minimizing the standard deviation variation between the $\log$ of the freshwater residence time for each watershed $i$ in the spatial model and the log of the mean residence time for that watershed's archetype using the Excel solver tool. The total standard deviation, $\mathrm{SD}_{\text {tot }}$ is the sum of the standard deviations for each of the three residence time archetypes:

$$
\begin{aligned}
\mathrm{SD}_{\text {tot }}= & \left\{\frac { 1 } { n } * \sum _ { \tau _ { \text { sea } i } = 0 } ^ { \tau _ { 1 2 } } \left[\left(\log \left(\tau_{\text {sea } i}\right)-\log \left(\tau_{\text {sea } A 1}\right)\right]^{2}\right.\right. \\
& +\sum_{\tau_{\text {sea } i}=\tau_{12}}^{\tau_{23}}\left[\log \left(\tau_{\text {sea } i}\right)-\log \left(\tau_{\text {sea } A 2}\right)\right]^{2} \\
& \left.+\sum_{\tau_{\text {sea } i=} \tau_{23}}^{\infty}\left[\log \left(\tau_{\text {sea } i}\right)-\log \left(\tau_{\text {sea } A 3}\right)\right]^{2}\right\}^{1 / 2}
\end{aligned}
$$

where $\tau_{i}=\frac{V_{i}}{Q_{i}}[\mathrm{~d}]$ is the water residence time in watershed $i(1 \leq i<135$ for the spatial IMPACT Europe model), calculated as the watershed volume $V_{i}$ $\left[\mathrm{m}^{3}\right]$ divided by the advection flow out of the watershed $Q_{i}\left[\mathrm{~m}^{3} / \mathrm{d}\right] ; \tau_{\text {sea } i}=$ $\tau_{i}+\sum_{f_{j \text { downstream }}} \tau_{j}[\mathrm{~d}]$ is the water residence time until reaching the sea, calculated by summing the residence time in watershed $i$ with the transfer fraction to all watersheds $j$ downstream of $i$ multiplied by their freshwater residence times.

$\tau_{\text {sea A1, }} \tau_{\text {sea A2 }}$ and $\tau_{\text {sea A3 }}$ are the residence times for each archetype, calculated based on the total volume of all watersheds corresponding to this archetype and the total advective flow out of all watershed flows corresponding to this archetype.

The mean freshwater residence time to sea is calculated as a surface weighted average of the water residence times of each watershed classified in one of the three archetypes. The calculated mean freshwater residence time of each watershed is presented in Section 3.3. We test 
the relevance of these archetypes by determining the variability in fate and intake fraction across emissions in each of the 135 watersheds described by these three archetypes.

The practitioner may choose the archetype based on the emission location by finding the archetype corresponding to the place of emission according to Fig. E.1.

\section{Results and discussion}

3.1. Inter-continental variation: comparison between spatially differentiated IMPACTWorld and nested USEtox model

\subsubsection{Residence times}

Fig. $2 \mathrm{a}$ presents the range of freshwater residence times to sea, comparing the nested continent-specific USEtox model to the fully connected IMPACTWorld model. These residence times vary by up to two orders of magnitude among sub-continental zones, with North Australia having one of the shortest times and North Africa having the longest. Values in the two models are similar for all sub-continental zones, with the highest difference being a factor 4 for the East Indies (W14). These differences in freshwater residence times to sea are due to different ways of calculating total water advection. IMPACTWorld outflows are advective flows based on river discharges out of the subcontinental zone (Global Runoff Data Centre, 2002), whereas USEtox uses a water balance approach based on rainfall, evapotranspiration, infiltration and runoff.

\subsubsection{Fate factors}

Fig. 2b compares the fate factors in freshwater for chemical emissions to freshwater for each sub-continental zone in each of the two models. These fate factors represent the chemical mass in the freshwater environment per unit flow emission (units of $\mathrm{kg}$ per $\mathrm{kg} /$ day), which corresponds to the residence time of each substance in freshwater (in days). For persistent pollutants that have a long degradation half-life in water $\left(\mathrm{t}_{1 / 2 \text { water }}\right)$, such as gamma-HCH (lindane) $\left(\mathrm{t}_{1 / 2 \text { water }}=\right.$ 1.9 years $)$ or aldrin ( $t_{1 / 2 \text { water }}=2.0$ years $)$, their fate is more sensitive to the zone's freshwater residence time to sea. The fate factors of these persistent pollutants can thus vary by more than one order of magnitude among sub-continental zones, with aldrin ranging from 10 days in North Australia to 199 days in North Africa in the USEtox parameterization (Fig. C.1 in Appendix C). For non-persistent substances, the emission location has little influence, and the fate factor is identical for all regions. $\mathrm{N}$-nitrosodiethylamine has $\mathrm{t}_{1 / 2 \text { water }}=6 \mathrm{~h}$, and thus has a fate factor of 0.36 day in all continents (Fig. C.1).

Discrepancies in fate factors between the two models are limited but observable, particularly for the sub-continental zones that have different freshwater residence times, such as W14 East Indies in Fig. 2a. W14 has a freshwater residence time of 19 days in IMPACTWorld and 80 days in USEtox. Thus persistent pollutants whose disappearance

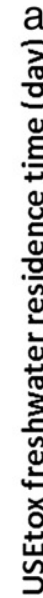

10000

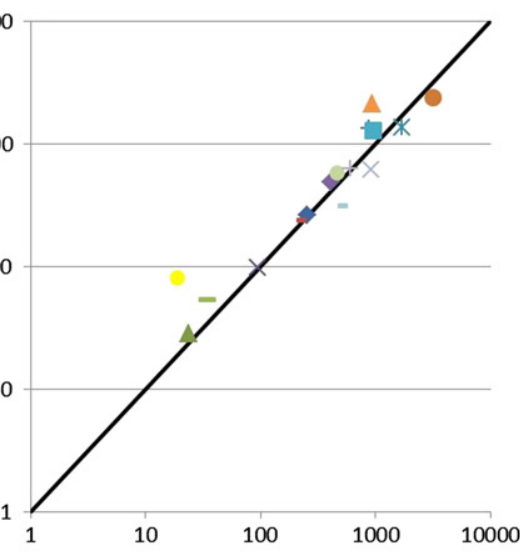

IMPACT World freshwater residence time (day)

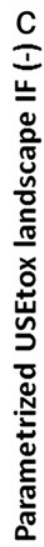

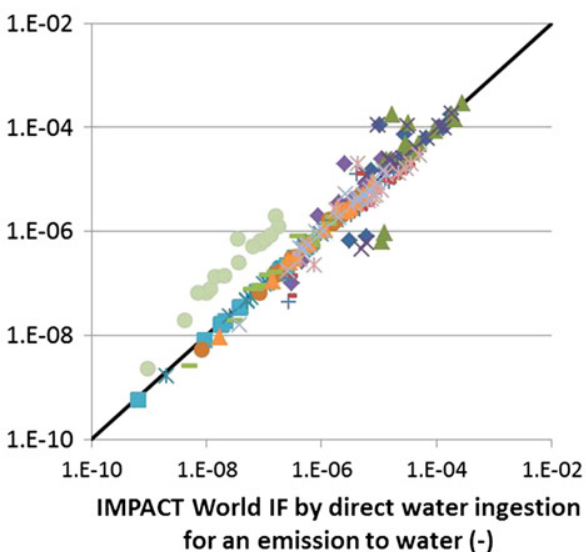

W2 Indochina

$\triangle$ W3 N. Australia

W4 S. Australia+

$*$ W5 s. Africa

W6 N. Africa

- W7 Argentina+

-W8 Brazil+

- w9 Central America

W10 US+

$\triangle$ W12 N. Eur. + N. Canada

W13 Europe+

W14 East Indies

- IND India

CHI China

- JAP Japan

- Hexabromobenzene

= N-Nitrosodiethylamine

- gamma-HCH (lindane)

$\triangle$ Folpet

$\times$ Methomyl

* Captan

- Methanol

+ Tetrachloroethylene

- carbon tetrachloride (CCl4)

- Mirex

$\triangle$ Formaldehyde

Hexachlorobenzene

Thiram

- Di(n-octyl) phthalate
W1 West Asia

-W2 Indochina

$\triangle$ W3 N. Australia

$\times$ W4 S. Australia+

W5 S. Africa

- W6 N. Africa

- W7 Argentina+

-W8 Brazil+

-W9 Central America

W10us+

$\triangle$ W12 N. Eur. + N. Canada

W13 Europe+

W14 East Indies

IND India

CHI China

-JAP Japan

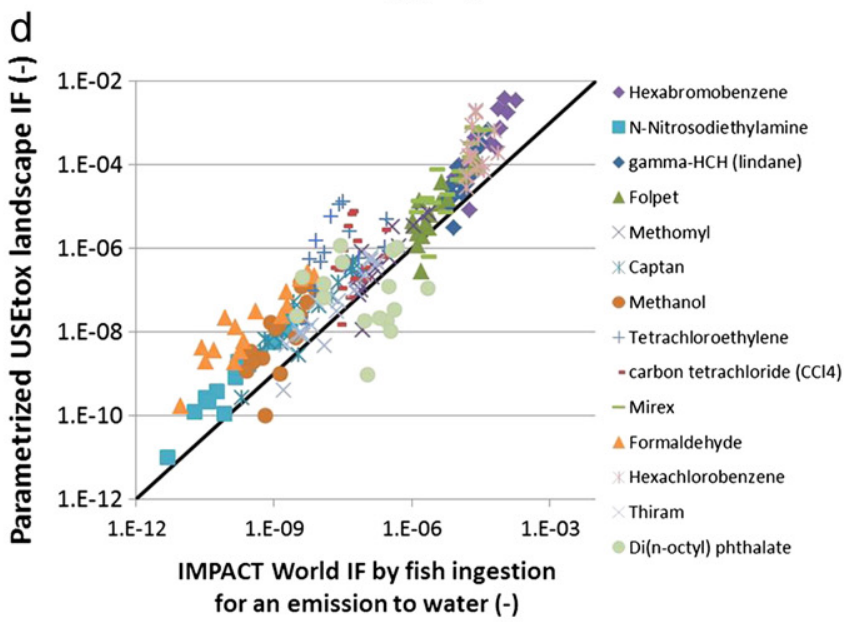

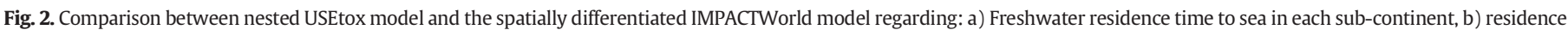
time in freshwater of 36 representative chemicals emitted in each sub-continent, c) intake fraction through freshwater ingestion, and d) intake fraction through fish ingestion. 
is not driven by degradation, evaporation or sedimentation (e.g., methomyl) have fate factors limited to 19 days in IMPACTWorld (and 80 days in USEtox). Yet Fig. 2b shows one outlier that exceeds this maximum fate factor of 19 days - hexachlorobenzene. This is due to a dynamic that can only be captured by an interconnected spatial model like IMPACTWorld, in which a pollutant can be transferred from one sub-continental zone into an adjacent zone with a higher freshwater residence time to sea. The fate factor also depends on the product of the inter-continental transfer fraction from water to air (Eq. C2 in Appendix C) with the water residence time in the receiving compartment. The fate factor can therefore exceed the water residence time to sea of the emission compartment if it is transferred to the freshwater a

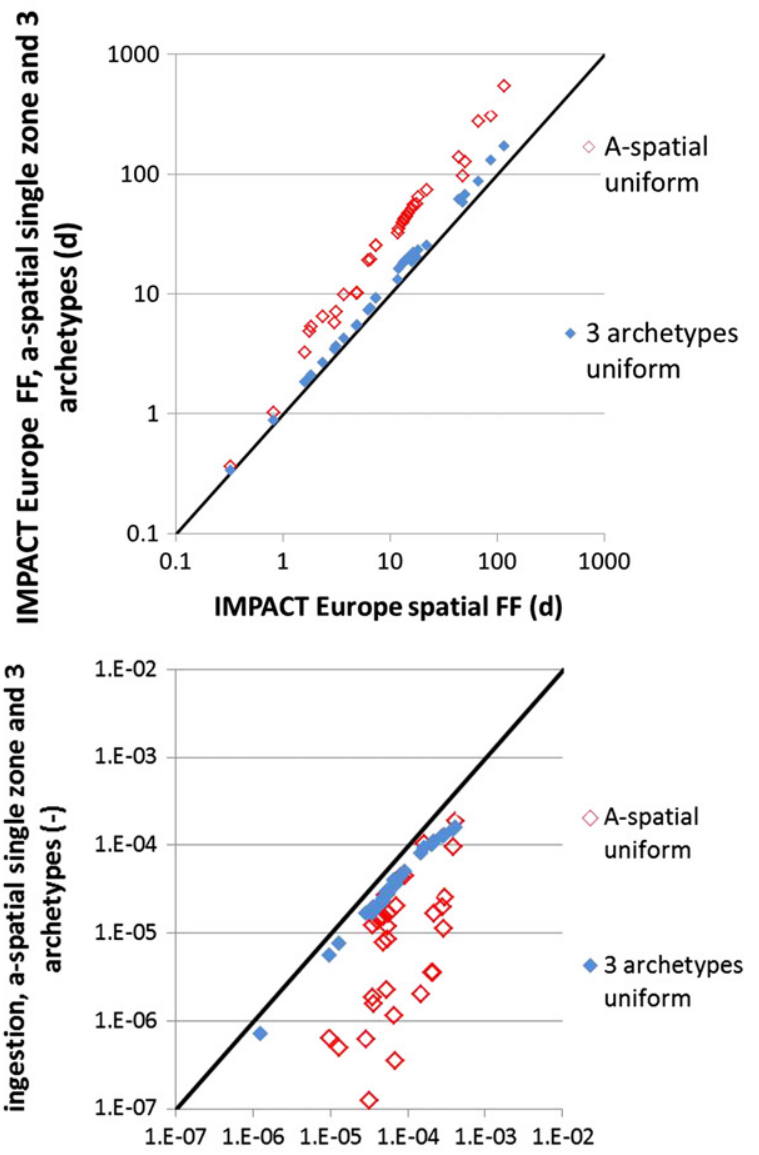

IMPACT Europe spatial IF through water ingestion (-)

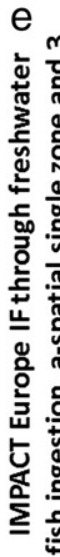

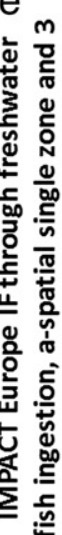

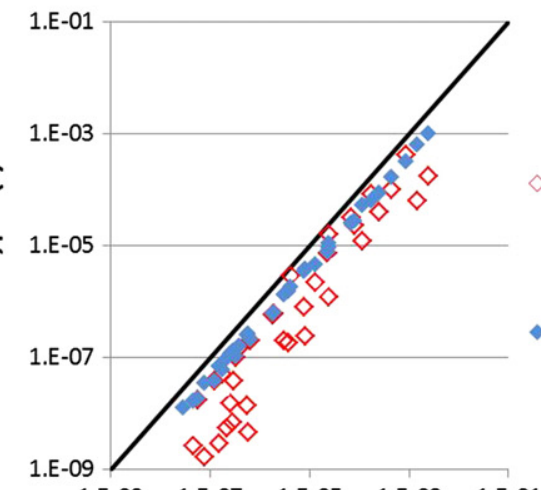

1.E-09 1.E-07 1.E-05 1.E-03 1.E-01

IMPACT Europe spatial IF through freshwater fish ingestion (-) b

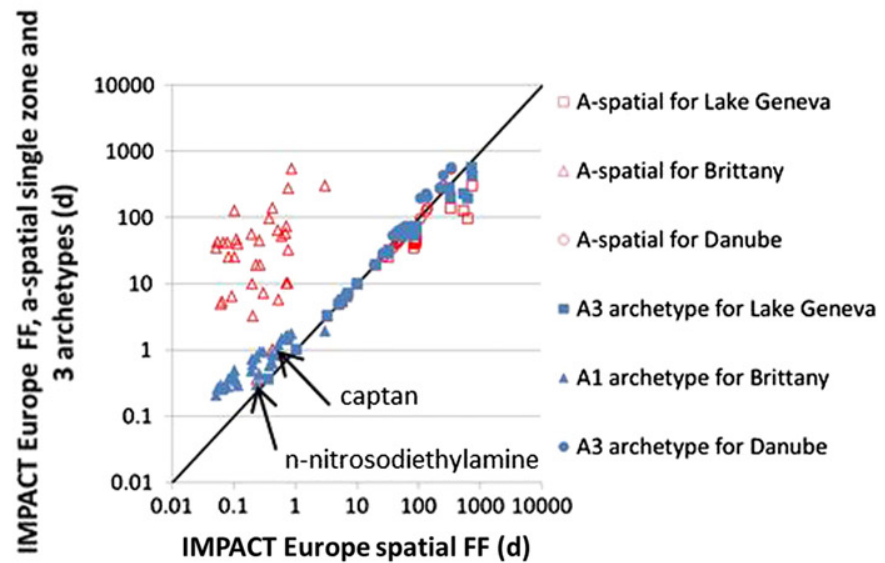

d

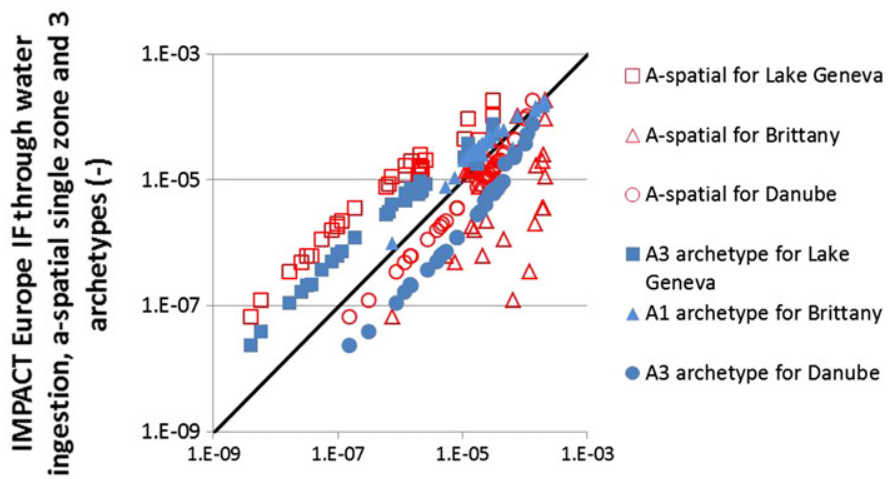

IMPACT Europe spatial IF through water ingestion (-)

$f$

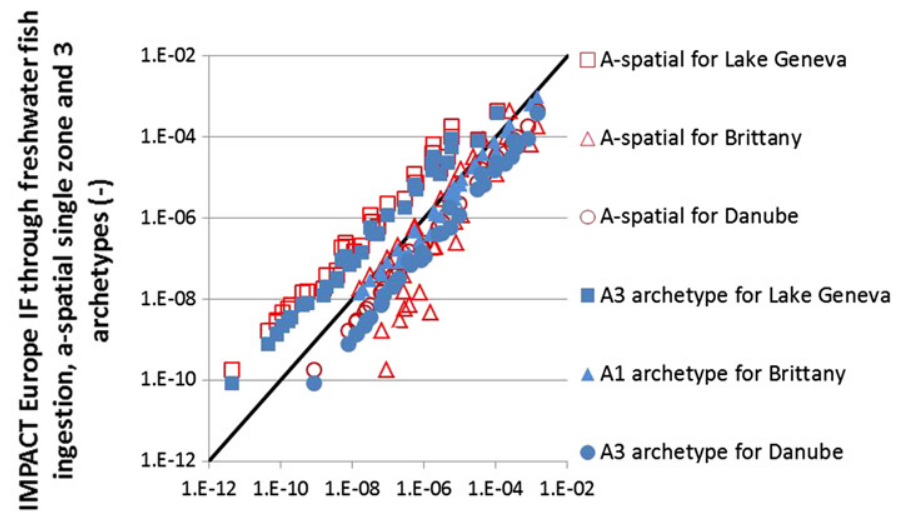

INIPACT Europe spatial IF through freshwater fish ingestion (-)

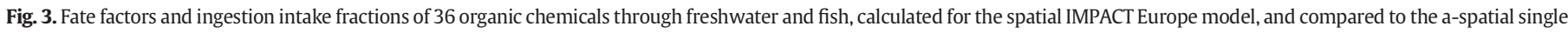

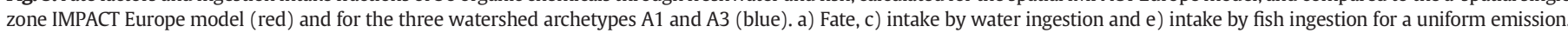
b) Fate, d) intake by water ingestion and f) intake by fish ingestion for point source emissions in Lake Geneva ( $\square$ ), Brittany ( $\Delta$ ), and Danube (O). 
compartment of another sub-continental zone with higher freshwater residence time. In our case, the fate factor of hexachlorobenzene emitted in W14 (42 days) is driven by the fraction of the pollutant transferred through air to Antarctica (W11) (1.2\%). Hexachlorobenzene is highly volatile $\left(\mathrm{K}_{\mathrm{H}}=170 \mathrm{~Pa} \cdot \mathrm{m}^{3} \cdot \mathrm{mol}^{-1}\right)$ and persistent $\left(\mathrm{t}_{1 / 2 \mathrm{air}}=\right.$ 0.84 year and $t_{1 / 2 \text { water }}=6.3$ years $)$, and the IMPACTWorld model freshwater residence time in Antarctica (W11) is much higher than the hexachlorobenzene half-life. The fate of hexachlorobenzene in W11 is thus not limited by the freshwater residence time of the emitting compartment.

\subsubsection{Intake fractions}

Fig. $2 \mathrm{c}$ and d display the range of human intake fractions through freshwater ingestion and fish ingestion, respectively, due to

a

\begin{tabular}{|c|c|c|}
\hline $\begin{array}{l}\text { A N-Nitrosodiethylamine } \\
\text { * Hexachlorocyclopentadiene } \\
\text { - Cypermethrin } \\
\text { whiram } \\
\text { X PCBs } \\
\text { - Heptachlor } \\
\text { Acephate } \\
\text { 1,3-butadiene } \\
\text { - 1,1,2,2-Tetrachloroethane } \\
\text { Hexachlorobutadiene } \\
\text { Heptachlor epoxide } \\
\text { - Aldrin }\end{array}$ & $\begin{array}{l}\text { Captan } \\
\text { - Formaldehyde } \\
\text { - Mirex } \\
\text { A Benomyl } \\
\text { - Anthracene } \\
\text { - Dicofol } \\
\text { - Hexabromobenzene } \\
\text { Trifluralin } \\
\text { - 1,2-Dichloroethane } \\
\text { Endosulfan } \\
\text { - Folpet } \\
\text { - Hexachlorobenzene }\end{array}$ & $\begin{array}{l}\times \text { Methanol } \\
+ \text { Ethyl acetate } \\
\text { dimethylphthalate (DMP) } \\
\text { Di(n-octyl) phthalate } \\
\text { + Propoxur } \\
\text { - Pronamide } \\
\text { carbon tetrachloride (CCl4) } \\
\text { 1,4-dichlorobenzene } \\
\text { Tetrachloroethylene } \\
\text { Methomyl } \\
\text { gamma-HCH (lindane) }\end{array}$ \\
\hline
\end{tabular}

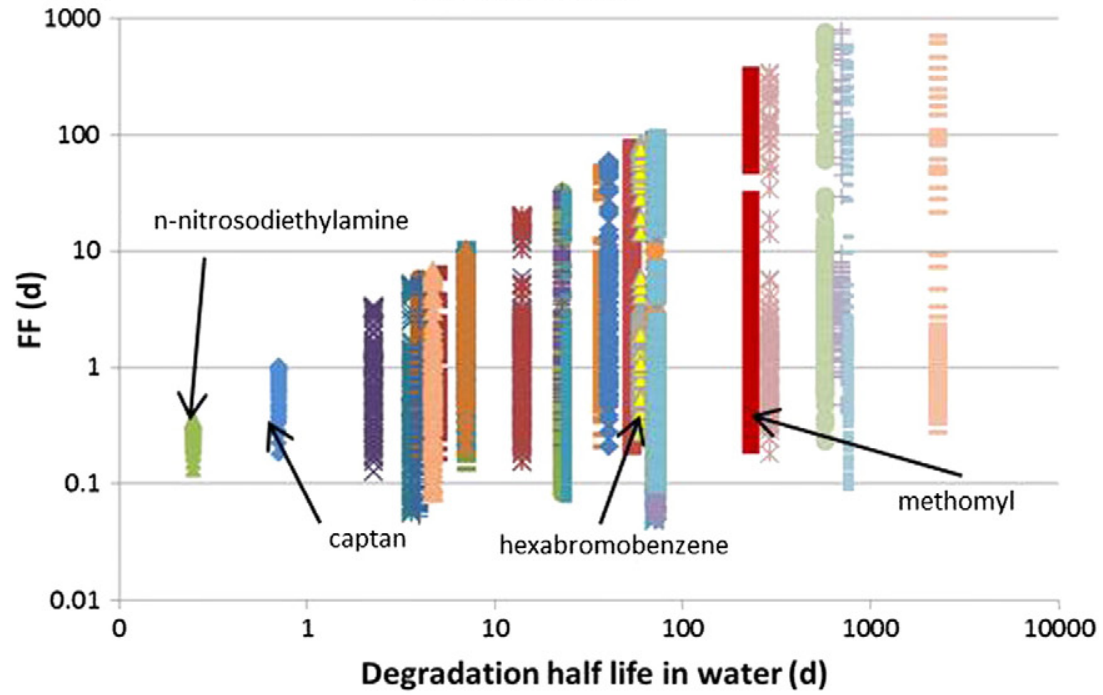

b

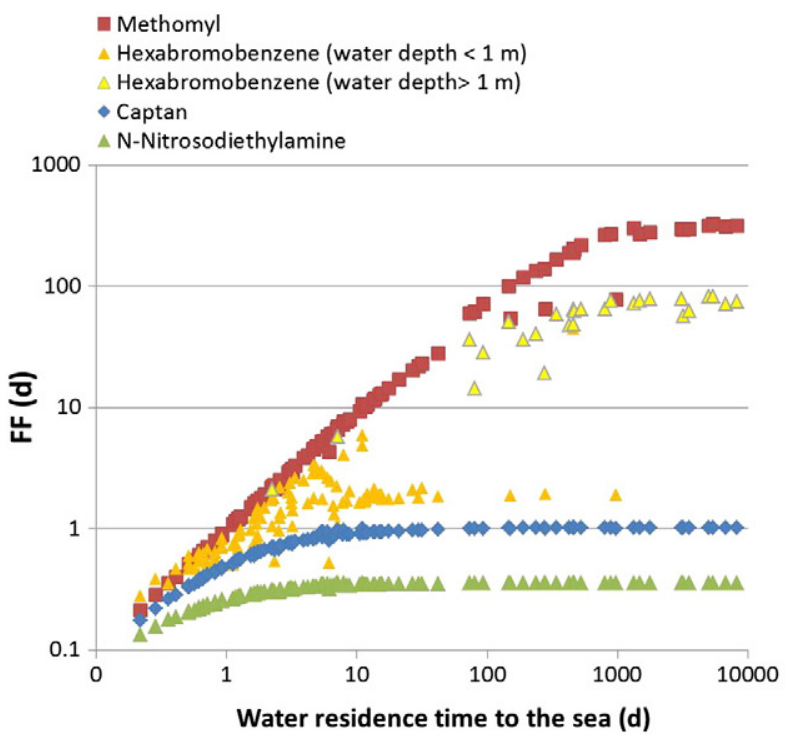

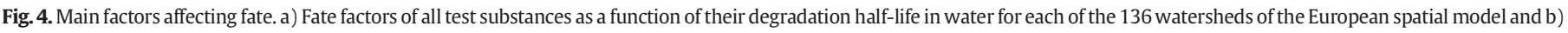

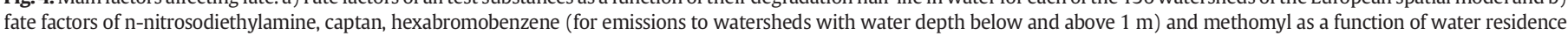
time to sea for each of the 136 watersheds of the European spatial model. 
freshwater emissions of various substances. In addition to variation of water residence time in each sub-continental zone (influenced by water surface and depth), inter-continental variation also depends on landscape parameters related to exposure, such as population density and various food product intake rates. These parameters lead to variation in intake fractions for the same substance in different sub-continental zones of more than three orders of magnitude, not only for persistent substances, but also for some easily degradable chemicals. Given the many parameters that influence intake fraction, difference neither in spatialization nor in model algorithms causes substantial deviation of intake fractions between the two models, which generally remain within two orders of magnitude. Intake fraction results for other pathways from freshwater emissions, as well as intake fraction for all pathways from air emissions, are presented in Appendix C.

The previous results show that considered zones cover a wide range of landscape parameters corresponding to a comprehensive overview of sub-continental fate and intake fraction variability.

\subsection{Intra-continental variation and importance of spatialization: Europe a-spatial and Europe spatial IMPACT model}

This section analyses the intra-continental variation of fate and intake fractions in Europe on a watershed scale. Fig. 3 uses a red symbol to compare the fate factors $(a, b)$ and intake fractions ( $c-f)$ of the a-spatial with those of the spatial IMPACT model, for both uniform and point-source emissions (i.e., respectively for surface weighted emissions and emissions in specific European watersheds). Results for the three watershed archetypes are displayed in blue and discussed in Section 3.3.

\subsubsection{Fate factors}

For a uniform emission (when a substance is uniformly emitted on the surface covered by the model), Fig. 3a shows that fate factors smaller than 3 days (lower left portion of the graph) are similar for the spatial and a-spatial versions of the model. For more persistent pollutants and regions with higher freshwater residence times to sea, the a-spatial single box model overestimates the fate factor by up to a factor 5 when compared to the spatially differentiated model due to the high freshwater residence time to sea in the aspatial model $(4.1 \mathrm{y})$.

For point-source emissions (when a substance is emitted in a defined single geographical location covered by the model) in locations with increasing freshwater residence time to sea (Brittany is 0.81 days (corresponds to archetype A1), Danube is 1.4 years (corresponds to archetype A3) and Lake Geneva is 13.6 years to the sea (corresponds to archetype A3)), Fig. 3b shows that the a-spatial model accuracy depends on the watershed in which the pollutant is emitted and on the pollutant persistence in freshwater. For highly degradable pollutants with degradation half-lives less than 3 days, such as n-nitrosodiethylamine and captan, a-spatial fate factors are aligned with the spatial ones for all watersheds. This is not the case for more persistent pollutants for which the freshwater residence time to sea of the emitting compartment is a key factor. For an emission to Lake Geneva, the a-spatial single box model only slightly underestimates the residence time, since the a-spatial freshwater residence time to sea ( 4.1 years) is three times higher than Lake Geneva's freshwater residence time to sea (13.6 years in the spatial model). For the same reason, fate factors for an emission into the Danube are slightly overestimated in the a-spatial model (freshwater residence time in the Danube watershed is 1.4 years). Brittany a-spatial fate factors are overestimated by about 3 orders of magnitude because of the short freshwater residence time to sea in this coastal region ( 0.81 day $=0.002$ year). When an emission location is known, a spatially differentiated model can thus improve the model accuracy by up to 2 - to 3 orders of magnitude.

\subsubsection{Intake fractions}

Human intake fractions for freshwater and fish ingestion are represented in Fig. $3 c$ to f. For a uniform emission, the a-spatial model underestimates both these intake fractions by up to 2 orders of magnitude (Fig. 3c and e). This trend is different from that observed for fate prediction due to differences in exposure estimation between these two models. Despite the low freshwater residence time in coastal zones, exposure factors tend to be higher in these zones, compared to inland watersheds with high freshwater residence times. These variations in exposure also influence the intake fraction for a point source emission into freshwater (Fig. 3d and f), such that the a-spatial model underestimates the intake fraction for an emission in Brittany. The model overestimates intake for emissions into a large body of water such as the Lake Geneva watershed.

\subsubsection{Key parameters affecting fate}

To further analyse the main parameters responsible for the spatial variation of fate factors, Fig. 4a presents the variability in chemical fate for emissions in different European watersheds, as calculated by the spatially differentiated European IMPACT model. For easily degraded pollutants with a half-life lower than a day, such as nnitrosodiethylamine ( $t_{1 / 2}=6 \mathrm{~h}$ in freshwater), fate factors vary by less than one order of magnitude across European watersheds. Such highly degradable or volatile chemicals disappear before being advected out of the watershed and their residence times do not vary much across watersheds. On the contrary, fate can vary up to four orders of magnitude for persistent pollutants with half-lives larger than 100 days, such as methomyl ( $\mathrm{t}_{1 / 2}=230$ days in freshwater).

By displaying the fate factor as a function of the freshwater residence time for four pollutants with different levels of persistence in freshwater (n-nitrosodiethylamine has $\mathrm{t}_{1 / 2}=0.25$ day, captan has $\mathrm{t}_{1 / 2}=0.71$ day, hexabromobenzene has $\mathrm{t}_{1 / 2}=73$ days, and methomyl has $\mathrm{t}_{1 / 2}=$ 230 days), Fig. $4 \mathrm{~b}$ shows that the variability across watersheds is mostly explained by the freshwater residence time to sea. Whilst the fate factor of the short-lived n-nitrosodiethylamine is not influenced by freshwater residence time, fate factors for methomyl show a strong linear dependence on freshwater residence time. The distinction between emissions of hexabromobenzene in watersheds with a water depth below and above $1 \mathrm{~m}$ shows that outliers (watersheds for which fate factors are not limited by freshwater residence time) depend on the mean depth in the considered geographical unit that influences other loss processes,

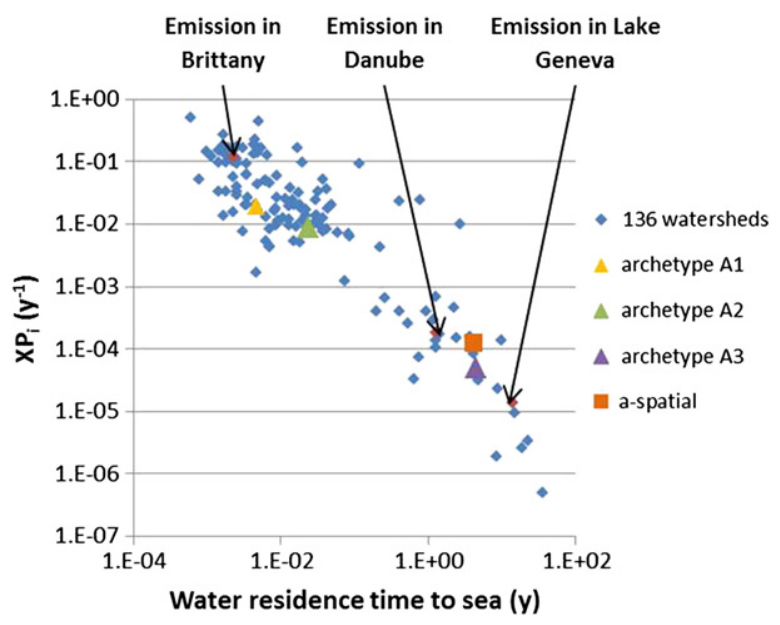

Fig. 5. Variation in methomyl exposure factor from freshwater ingestion for the spatial, archetype and a-spatial models, where $X P_{i}$ is the exposure factor for an emission in watershed, archetype or a-spatial zone $i$. 
such as volatilization or deposition rates. The higher the freshwater depth, the lower the volatilization and deposition rates and the greater the fate factor. Fig. D.1a and b show the same analysis applied to intake fractions through water ingestion.

\subsubsection{Key parameters affecting exposure}

To understand the main factors affecting the variability of the exposure factors $(X P)$ across Europe, we calculate for each watershed $i$ an equivalent exposure factor through freshwater ingestion and fish ingestion by dividing the intake fraction $\left(I F_{i}\right)$ by its fate factor $\left(F F_{i}\right): X P_{i}=I F_{i} /$ $F F_{i}[1 / \mathrm{d}]$. The resulting exposure factor can be interpreted as the equivalent fraction of the overall volume of water available that is taken in every day by the population.

Fig. 5 presents the exposure factors by freshwater ingestion as a function of the freshwater residence time to sea for all watersheds of the spatial model, for the three archetypes and for the a-spatial model. We observe a clear inverse relationship between the exposure factor and the freshwater residence time to sea; for watersheds with a short residence time to sea, such as Brittany, the available volume of water is limited and thus the equivalent fraction of the water volume taken in every day by the population is high. As the freshwater residence time to sea increases, the fraction of water taken in is reduced by more than two (Danube) to three (Lake Geneva) orders of magnitude.

\subsection{Freshwater archetype}

\subsubsection{Development of the archetype watersheds}

The previous section has shown that the freshwater residence time to sea is a major determinant of both fate and exposure. This residence time to sea (or the model boundary) has thus been used to define three water archetypes by minimizing the variation between the log of freshwater residence times of the spatial model and the log of the mean value of the archetype watershed, as described in Section 2.4. The resulting three archetypes have the following key characteristics. Archetype A1 covers coastal zones with short freshwater residence times, reaching the sea in less than 2 days, with an average value of 1.7 days, and a total volume of water of $0.073 \mathrm{~m}^{3}$ per $\mathrm{m}^{2}$ land area (also equal to the mean depth). Archetype A2 covers watersheds of medium freshwater residence times between 2 and 60 days, with an average of 8.6 days and a water volume of $0.27 \mathrm{~m}^{3}$ per $\mathrm{m}^{2}$ land area. Archetype A3 covers watersheds with freshwater residence times longer than 60 days, with an average residence time of 1600 days and a volume of water of $39 \mathrm{~m}^{3}$ per $\mathrm{m}^{2}$ land area.

Appendix D presents the archetype classification of each of the 136 watersheds of the IMPACT Europe spatial model, as well as the geographical delimitation of the three newly developed archetypes.

\subsubsection{Evaluation of the archetype model}

We evaluated the performance of this watershed archetype model by comparing the resulting fate and intake fraction of each test pollutant in each archetype to the IMPACT Europe spatial model results for uniform and point source emissions (blue markers in Fig. 3).

For a uniform emission, chemical fate factors of the archetype model are aligned with those of the Europe spatial model (Fig. 3a). For intake fractions through freshwater and freshwater fish ingestion, the archetype model also improves upon the a-spatial model estimation by substantially reducing the difference in results to within a factor two (Fig. $3 \mathrm{c}$ and e). This reflects the improvement in both fate and exposure modelling related to population density compared to the a-spatial model, given that the archetype A1 is composed of coastal areas and thus mimics more adequately the intake fraction related to coastal zones modelled with the Europe spatial model.

For a point source emission, the archetype model represents a substantial improvement over the a-spatial model, with fate factors generally within a factor five of the spatial model (Fig. 3b). This improvement is particularly stark for Brittany, because its freshwater residence time of 0.81 day is well approximated by the average residence time of 1.7 day in the archetype model. Fig. $3 \mathrm{~d}$ and $\mathrm{f}$ shows that the intake fractions are also improved in the archetype model, especially for a source emission in Brittany due to the modelling of higher exposure in coastal zones.

\section{Conclusions}

This paper develops continent-specific factors for the USEtox model and provides a first evaluation of the variability of fate and exposure induced by simplified approaches addressing spatial differentiation of toxic impacts such as: (1) region-specific nested models with a global surrounding box and (2) spatial archetypes based on key landscape parameters. It shows that simplifying models either to a nested model of continent-specific landscapes or to a model with a limited number of watershed archetypes still captures the main variability in impacts and may represent an efficient solution to account for spatial variations whilst limiting the complexity of the analysis.

Inter-continental variations in water residence time, fate and intake fraction are greater than one order of magnitude among the 17 zones assessed with the IMPACTWorld and USEtox models, due to differences in continent-specific landscape and population parameters. However, the model architecture of the surrounding box(es) (i.e., the single global box of USEtox or the interconnected continents of IMPACT) generally does not have a significant influence on results, with the exception of volatile and persistent pollutants in both air and water. A nested model, such as USEtox with a specific sub-continental parameterization, is thus well suited to model inter-continental variations in fate and exposure for most substances.

For intra-continental variation, an a-spatial model might substantially overestimate the chemical fate and characterisation factors for freshwater eco-toxicity, by up to 3 orders of magnitude when compared to a spatially regionalized multimedia model representing the variations in hydrology and water use between watersheds. We identified freshwater residence time to sea as a key parameter affecting the variation in fate and exposure of persistent chemicals in water, and thus developed a set of three watershed archetypes based on this residence time as an alternative to a spatially differentiated model. This archetype model predicts aquatic fate and intake fractions within a factor 5 of those predicted by a detailed spatial model, whilst decreasing model complexity.

This work is an important step towards a regionalized assessment of toxic impact in the context of LCA and chemical screening. Further research work should be pursued to evaluate the robustness and the accuracy of the proposed archetypes applying a model with finer spatial resolution capabilities, whilst maintaining global coverage and multimedia modelling capacities. Models running on recently available hydrological datasets at $0.5^{\circ}$ and $15^{\prime}$ should provide better basis to determine the optimal number of archetypes and further explore landscape key characteristics influencing fate and exposure across continents.

\section{Acknowledgements}

This work is financially supported by the project Life Cycle Impact Assessment Methods for Improved Sustainability Characterisation of Technologies (LC-IMPACT), contract no. 243827, funded by the European Commission under the Seventh Framework Programme. The International Life Cycle Chair (a research unit of the CIRAIG) would like to acknowledge the financial support of its industrial partners: ArcelorMittal, Bombardier, Hydro-Québec, LVMH, Michelin, Mouvement des caisses Desjardins, Nestlé, RECYC-QUÉBEC, RONA, SAQ Solvay, Total, Umicore and Veolia Environnement. The authors would like to also to thank Cedric Wannaz for his scientific support. 
Table A.1

USEtox landscape parameters for the 17 sub-continental and the 8 zone continental resolution (the title terminology is the same as in the USEtox tool).

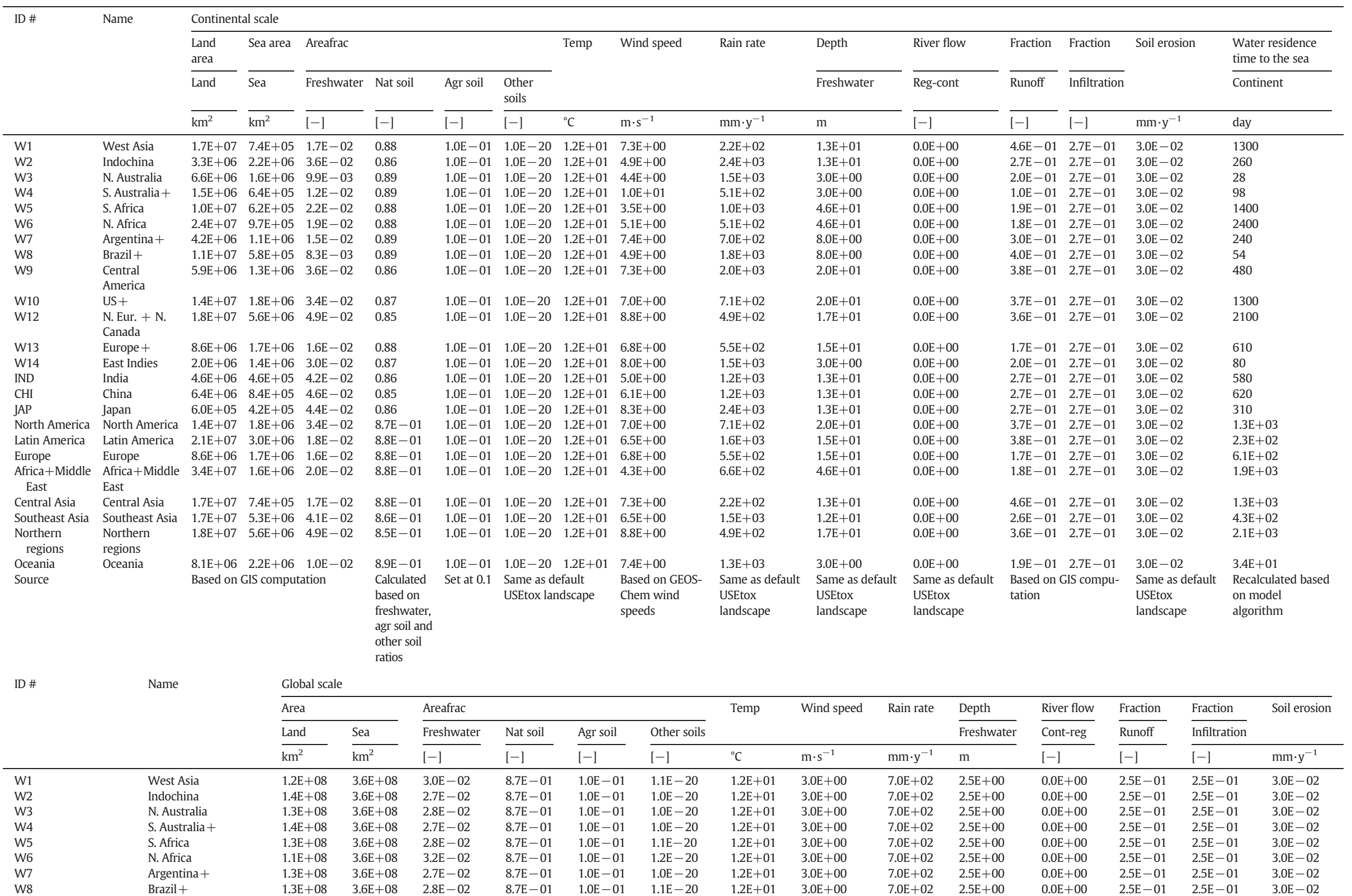




\begin{tabular}{|c|c|c|c|c|c|c|c|c|c|c|c|c|c|c|c|}
\hline W9 & Central America & $1.3 \mathrm{E}+08$ & $3.6 \mathrm{E}+08$ & $2.7 \mathrm{E}-02$ & $8.7 E-01$ & $1.0 \mathrm{E}-01$ & $1.0 \mathrm{E}-20$ & $1.2 \mathrm{E}+01$ & $3.0 \mathrm{E}+00$ & $7.0 \mathrm{E}+02$ & $2.5 \mathrm{E}+00$ & $0.0 \mathrm{E}+00$ & $2.5 \mathrm{E}-01$ & $2.5 \mathrm{E}-01$ & $3.0 \mathrm{E}-02$ \\
\hline W10 & US + & $1.2 \mathrm{E}+08$ & $3.6 \mathrm{E}+08$ & $2.9 \mathrm{E}-02$ & $8.7 E-01$ & $1.0 \mathrm{E}-01$ & $1.1 \mathrm{E}-20$ & $1.2 \mathrm{E}+01$ & $3.0 \mathrm{E}+00$ & $7.0 \mathrm{E}+02$ & $2.5 \mathrm{E}+00$ & $0.0 \mathrm{E}+00$ & $2.5 \mathrm{E}-01$ & $2.5 \mathrm{E}-01$ & $3.0 \mathrm{E}-02$ \\
\hline W12 & N. Eur. + N. Canada & $1.2 \mathrm{E}+08$ & $3.6 \mathrm{E}+08$ & $3.0 \mathrm{E}-02$ & $8.8 \mathrm{E}-01$ & $1.0 \mathrm{E}-01$ & $1.2 \mathrm{E}-20$ & $1.2 \mathrm{E}+01$ & $3.0 \mathrm{E}+00$ & $7.0 \mathrm{E}+02$ & $2.5 \mathrm{E}+00$ & $0.0 \mathrm{E}+00$ & $2.5 \mathrm{E}-01$ & $2.5 \mathrm{E}-01$ & $3.0 \mathrm{E}-02$ \\
\hline W13 & Europe + & $1.3 \mathrm{E}+08$ & $3.6 \mathrm{E}+08$ & $2.8 \mathrm{E}-02$ & $8.7 E-01$ & $1.0 \mathrm{E}-01$ & $1.1 \mathrm{E}-20$ & $1.2 \mathrm{E}+01$ & $3.0 \mathrm{E}+00$ & $7.0 \mathrm{E}+02$ & $2.5 \mathrm{E}+00$ & $0.0 \mathrm{E}+00$ & $2.5 \mathrm{E}-01$ & $2.5 \mathrm{E}-01$ & $3.0 \mathrm{E}-02$ \\
\hline W14 & East Indies & $1.4 \mathrm{E}+08$ & $3.6 \mathrm{E}+08$ & $2.7 E-02$ & $8.7 E-01$ & $1.0 \mathrm{E}-01$ & $1.0 \mathrm{E}-20$ & $1.2 \mathrm{E}+01$ & $3.0 \mathrm{E}+00$ & $7.0 \mathrm{E}+02$ & $2.5 \mathrm{E}+00$ & $0.0 \mathrm{E}+00$ & $2.5 \mathrm{E}-01$ & $2.5 \mathrm{E}-01$ & $3.0 \mathrm{E}-02$ \\
\hline IND & India & $1.3 \mathrm{E}+08$ & $3.6 \mathrm{E}+08$ & $2.7 E-02$ & $8.7 E-01$ & $1.0 \mathrm{E}-01$ & $1.0 \mathrm{E}-20$ & $1.2 \mathrm{E}+01$ & $3.0 \mathrm{E}+00$ & $7.0 \mathrm{E}+02$ & $2.5 \mathrm{E}+00$ & $0.0 \mathrm{E}+00$ & $2.5 \mathrm{E}-01$ & $2.5 \mathrm{E}-01$ & $3.0 \mathrm{E}-02$ \\
\hline CHI & China & $1.3 \mathrm{E}+08$ & $3.6 \mathrm{E}+08$ & $2.8 \mathrm{E}-02$ & $8.7 E-01$ & $1.0 \mathrm{E}-01$ & $1.0 \mathrm{E}-20$ & $1.2 \mathrm{E}+01$ & $3.0 \mathrm{E}+00$ & $7.0 \mathrm{E}+02$ & $2.5 \mathrm{E}+00$ & $0.0 \mathrm{E}+00$ & $2.5 \mathrm{E}-01$ & $2.5 \mathrm{E}-01$ & $3.0 \mathrm{E}-02$ \\
\hline JAP & Japan & $1.4 \mathrm{E}+08$ & $3.6 \mathrm{E}+08$ & $2.6 \mathrm{E}-02$ & $8.7 E-01$ & $1.0 \mathrm{E}-01$ & $1.0 \mathrm{E}-20$ & $1.2 \mathrm{E}+01$ & $3.0 \mathrm{E}+00$ & $7.0 \mathrm{E}+02$ & $2.5 \mathrm{E}+00$ & $0.0 \mathrm{E}+00$ & $2.5 \mathrm{E}-01$ & $2.5 \mathrm{E}-01$ & $3.0 \mathrm{E}-02$ \\
\hline North America & North America & $1.2 \mathrm{E}+08$ & $3.6 \mathrm{E}+08$ & $2.9 \mathrm{E}-02$ & $8.7 E-01$ & $1.0 \mathrm{E}-01$ & $1.1 \mathrm{E}-20$ & $1.2 \mathrm{E}+01$ & $3.0 \mathrm{E}+00$ & $7.0 \mathrm{E}+02$ & $2.5 \mathrm{E}+00$ & $0.0 \mathrm{E}+00$ & $2.5 \mathrm{E}-01$ & $2.5 \mathrm{E}-01$ & $3.0 \mathrm{E}-02$ \\
\hline Latin America & Latin America & $1.2 \mathrm{E}+08$ & $3.6 \mathrm{E}+08$ & $3.1 \mathrm{E}-02$ & $8.7 E-01$ & $1.0 \mathrm{E}-01$ & $1.2 \mathrm{E}-20$ & $1.2 \mathrm{E}+01$ & $3.0 \mathrm{E}+00$ & $7.0 \mathrm{E}+02$ & $2.5 \mathrm{E}+00$ & $0.0 \mathrm{E}+00$ & $2.5 \mathrm{E}-01$ & $2.5 \mathrm{E}-01$ & $3.0 \mathrm{E}-02$ \\
\hline Europe & Europe & $1.3 \mathrm{E}+08$ & $3.6 \mathrm{E}+08$ & $2.8 \mathrm{E}-02$ & $8.7 E-01$ & $1.0 \mathrm{E}-01$ & $1.1 \mathrm{E}-20$ & $1.2 \mathrm{E}+01$ & $3.0 \mathrm{E}+00$ & $7.0 \mathrm{E}+02$ & $2.5 \mathrm{E}+00$ & $0.0 \mathrm{E}+00$ & $2.5 \mathrm{E}-01$ & $2.5 \mathrm{E}-01$ & $3.0 \mathrm{E}-02$ \\
\hline Africa + Middle East & Africa + Middle East & $1.0 \mathrm{E}+08$ & $3.6 \mathrm{E}+08$ & $3.5 \mathrm{E}-02$ & $8.7 E-01$ & $1.0 \mathrm{E}-01$ & $1.3 \mathrm{E}-20$ & $1.2 \mathrm{E}+01$ & $3.0 \mathrm{E}+00$ & $7.0 \mathrm{E}+02$ & $2.5 \mathrm{E}+00$ & $0.0 \mathrm{E}+00$ & $2.5 \mathrm{E}-01$ & $2.5 \mathrm{E}-01$ & $3.0 \mathrm{E}-02$ \\
\hline Central Asia & Central Asia & $1.2 \mathrm{E}+08$ & $3.6 \mathrm{E}+08$ & $3.0 \mathrm{E}-02$ & $8.7 E-01$ & $1.0 \mathrm{E}-01$ & $1.1 \mathrm{E}-20$ & $1.2 \mathrm{E}+01$ & $3.0 E+00$ & $7.0 \mathrm{E}+02$ & $2.5 \mathrm{E}+00$ & $0.0 \mathrm{E}+00$ & $2.5 \mathrm{E}-01$ & $2.5 \mathrm{E}-01$ & $3.0 \mathrm{E}-02$ \\
\hline Southeast Asia & Southeast Asia & $1.2 \mathrm{E}+08$ & $3.6 \mathrm{E}+08$ & $3.0 \mathrm{E}-02$ & $8.8 \mathrm{E}-01$ & $1.0 \mathrm{E}-01$ & $1.1 \mathrm{E}-20$ & $1.2 \mathrm{E}+01$ & $3.0 \mathrm{E}+00$ & $7.0 \mathrm{E}+02$ & $2.5 \mathrm{E}+00$ & $0.0 \mathrm{E}+00$ & $2.5 \mathrm{E}-01$ & $2.5 \mathrm{E}-01$ & $3.0 \mathrm{E}-02$ \\
\hline Northern regions & Northern regions & $1.2 \mathrm{E}+08$ & $3.6 \mathrm{E}+08$ & $3.0 \mathrm{E}-02$ & $8.8 \mathrm{E}-01$ & $1.0 \mathrm{E}-01$ & $1.2 \mathrm{E}-20$ & $1.2 \mathrm{E}+01$ & $3.0 \mathrm{E}+00$ & $7.0 \mathrm{E}+02$ & $2.5 \mathrm{E}+00$ & $0.0 \mathrm{E}+00$ & 2.5E -01 & 2.5E -01 & $3.0 \mathrm{E}-02$ \\
\hline Oceania & Oceania & $1.3 \mathrm{E}+08$ & $3.6 \mathrm{E}+08$ & $2.8 \mathrm{E}-02$ & $8.7 E-01$ & $1.0 \mathrm{E}-01$ & $1.1 \mathrm{E}-20$ & $1.2 \mathrm{E}+01$ & $3.0 \mathrm{E}+00$ & $7.0 \mathrm{E}+02$ & $2.5 \mathrm{E}+00$ & $0.0 \mathrm{E}+00$ & $2.5 \mathrm{E}-01$ & $2.5 \mathrm{E}-01$ & $3.0 \mathrm{E}-02$ \\
\hline
\end{tabular}

Source

ID \# Nam

$\begin{array}{lrr}1.3 \mathrm{E}+08 & 3.6 \mathrm{E}+08 & 2.8 \mathrm{E}-02 \\ & \end{array}$

Same as default USEtox landscape

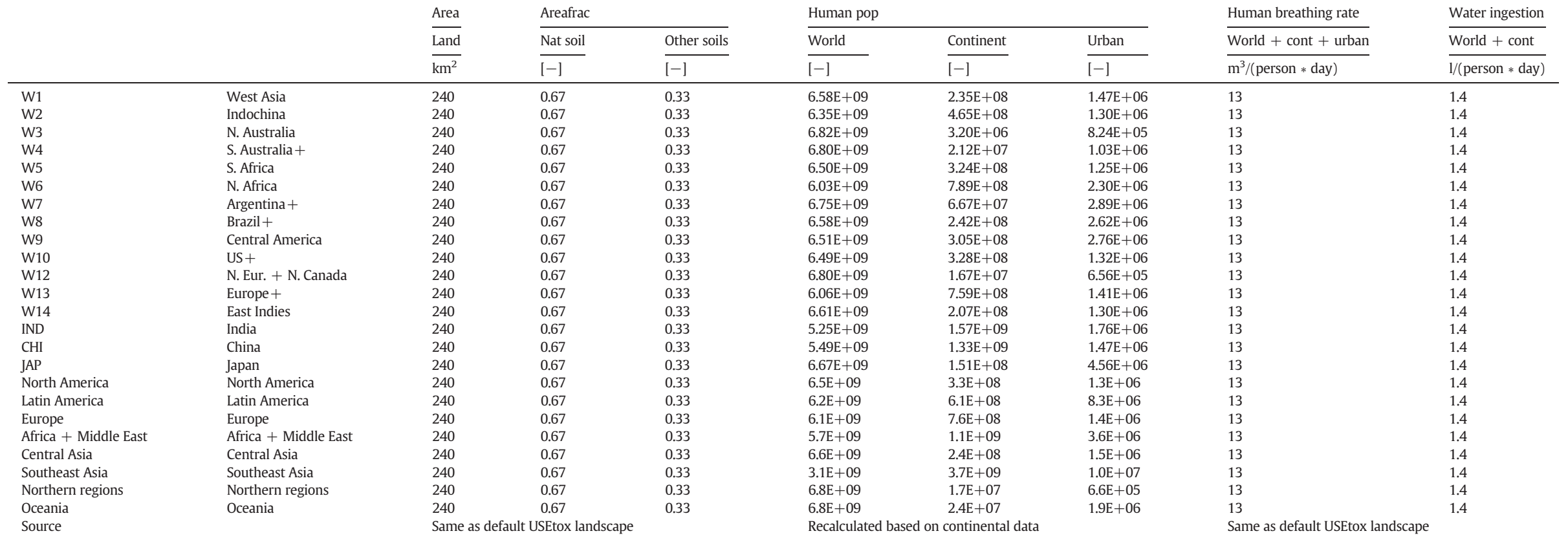

\begin{tabular}{|c|c|c|c|c|c|c|c|c|c|c|c|c|c|}
\hline \multirow[t]{4}{*}{ ID \# } & \multirow[t]{4}{*}{ Name } & \multicolumn{12}{|c|}{ Production-based intake rates } \\
\hline & & \multicolumn{2}{|c|}{ Exposed produce } & \multirow{3}{*}{$\begin{array}{l}\begin{array}{l}\text { Unexposed } \\
\text { produce }\end{array} \\
\text { World } \\
\mathrm{kg} / \\
\text { (day } * \text { capita) }\end{array}$} & \multirow{3}{*}{$\begin{array}{l}\begin{array}{l}\text { Unexposed } \\
\text { produce }\end{array} \\
\text { Continent } \\
\mathrm{kg} / \\
\text { (day } * \text { capita) }\end{array}$} & \multirow{3}{*}{$\begin{array}{l}\text { Meat } \\
\text { World } \\
\mathrm{kg} / \\
\text { (day * capita) }\end{array}$} & \multirow{3}{*}{$\begin{array}{l}\text { Meat } \\
\text { Continent } \\
\mathrm{kg} / \\
\text { (day } * \text { capita) }\end{array}$} & \multirow{3}{*}{$\begin{array}{l}\begin{array}{l}\text { Dairy } \\
\text { products }\end{array} \\
\text { World } \\
\mathrm{kg} / \\
\text { (day * capita) }\end{array}$} & \multirow{3}{*}{$\begin{array}{l}\begin{array}{l}\text { Dairy } \\
\text { products }\end{array} \\
\text { Continent } \\
\mathrm{kg} / \\
\text { (day } * \text { capita) }\end{array}$} & \multirow{3}{*}{$\begin{array}{l}\begin{array}{l}\text { Fish } \\
\text { freshwater }\end{array} \\
\text { World } \\
\mathrm{kg} / \\
\text { (day * capita) }\end{array}$} & \multirow{3}{*}{$\begin{array}{l}\text { Fish } \\
\text { freshwater } \\
\text { Continent } \\
\mathrm{kg} / \\
\text { (day * capita) }\end{array}$} & \multirow{3}{*}{$\begin{array}{l}\begin{array}{l}\text { Fish coastal } \\
\text { marine } \\
\text { freshwater }\end{array} \\
\text { World } \\
\mathrm{kg} / \\
\text { (day * capita) }\end{array}$} & \multirow{3}{*}{$\begin{array}{l}\begin{array}{l}\text { Fish coastal } \\
\text { marine } \\
\text { freshwater }\end{array} \\
\text { Continent } \\
\mathrm{kg} / \\
\text { (day } * \text { capita) }\end{array}$} \\
\hline & & World & Continent & & & & & & & & & & \\
\hline & & $\begin{array}{l}\mathrm{kg} / \\
\text { (day } * \text { capita) }\end{array}$ & $\begin{array}{l}\mathrm{kg} / \\
\text { (day * capita) }\end{array}$ & & & & & & & & & & \\
\hline W1 & West Asia & 2.13 & 1.71 & 0.37 & 0.33 & 0.10 & 0.08 & 0.24 & 0.26 & 0.01 & 0.011 & 0.04 & 0.05 \\
\hline W2 & Indochina & 2.08 & 2.57 & 0.38 & 0.22 & 0.10 & 0.05 & 0.25 & 0.01 & 0.01 & 0.008 & 0.03 & 0.06 \\
\hline W3 & N. Australia & 2.11 & 10.45 & 0.37 & 0.18 & 0.09 & 0.51 & 0.24 & 1.39 & 0.01 & 0.006 & 0.03 & 6.65 \\
\hline W4 & S. Australia + & 2.10 & 9.02 & 0.37 & 0.21 & 0.09 & 0.60 & 0.23 & 2.84 & 0.01 & 0.004 & 0.03 & 0.61 \\
\hline
\end{tabular}




\begin{tabular}{|c|c|c|c|c|c|c|c|c|c|c|c|c|c|}
\hline \multirow[t]{4}{*}{ ID \# } & \multirow[t]{4}{*}{ Name } & \multicolumn{12}{|c|}{ Production-based intake rates } \\
\hline & & \multicolumn{2}{|c|}{ Exposed produce } & \multirow{3}{*}{$\begin{array}{l}\begin{array}{l}\text { Unexposed } \\
\text { produce }\end{array} \\
\text { World } \\
\mathrm{kg} / \\
\text { (day } * \text { capita) }\end{array}$} & \multirow{3}{*}{$\begin{array}{l}\begin{array}{l}\text { Unexposed } \\
\text { produce }\end{array} \\
\text { Continent } \\
\mathrm{kg} / \\
\text { (day } * \text { capita) }\end{array}$} & \multirow{3}{*}{$\begin{array}{l}\text { Meat } \\
\text { World } \\
\mathrm{kg} / \\
\text { (day * capita) }\end{array}$} & \multirow{3}{*}{$\begin{array}{l}\text { Meat } \\
\text { Continent } \\
\mathrm{kg} / \\
\text { (day } * \text { capita) }\end{array}$} & \multirow{3}{*}{$\begin{array}{l}\begin{array}{l}\text { Dairy } \\
\text { products }\end{array} \\
\text { World } \\
\mathrm{kg} / \\
\text { (day * capita) }\end{array}$} & \multirow{3}{*}{$\begin{array}{l}\begin{array}{l}\text { Dairy } \\
\text { products }\end{array} \\
\text { Continent } \\
\mathrm{kg} / \\
\text { (day } * \text { capita) }\end{array}$} & \multirow{3}{*}{$\begin{array}{l}\begin{array}{l}\text { Fish } \\
\text { freshwater }\end{array} \\
\text { World } \\
\mathrm{kg} / \\
\text { (day * capita) }\end{array}$} & \multirow{3}{*}{$\begin{array}{l}\begin{array}{l}\text { Fish } \\
\text { freshwater }\end{array} \\
\text { Continent } \\
\mathrm{kg} / \\
\text { (day } * \text { capita) }\end{array}$} & \multirow{3}{*}{$\begin{array}{l}\begin{array}{l}\text { Fish coastal } \\
\text { marine } \\
\text { freshwater }\end{array} \\
\text { World } \\
\mathrm{kg} / \\
\text { (day * capita) }\end{array}$} & \multirow{3}{*}{$\begin{array}{l}\begin{array}{l}\text { Fish coastal } \\
\text { marine } \\
\text { freshwater }\end{array} \\
\text { Continent } \\
\mathrm{kg} / \\
\text { (day * capita) }\end{array}$} \\
\hline & & \multirow{2}{*}{$\frac{\text { World }}{\text { kg/ }}$} & \multirow{2}{*}{$\frac{\text { Continent }}{\mathrm{kg} /}$} & & & & & & & & & & \\
\hline & & & & & & & & & & & & & \\
\hline W5 & S. Africa & 2.17 & 1.03 & 0.37 & 0.44 & 0.10 & 0.03 & 0.25 & 0.06 & 0.01 & 0.006 & 0.04 & 0.03 \\
\hline w6 & N. Africa & 2.27 & 0.98 & 0.36 & 0.46 & 0.10 & 0.04 & 0.26 & 0.10 & 0.01 & 0.006 & 0.04 & 0.01 \\
\hline W7 & Argentina + & 2.09 & 4.92 & 0.37 & 0.46 & 0.09 & 0.23 & 0.23 & 0.57 & 0.01 & 0.002 & 0.03 & 0.31 \\
\hline w8 & Brazil + & 1.97 & 6.08 & 0.37 & 0.36 & 0.09 & 0.20 & 0.24 & 0.28 & 0.01 & 0.004 & 0.04 & 0.05 \\
\hline w9 & $\begin{array}{l}\text { Central } \\
\text { America }\end{array}$ & 2.09 & 2.62 & 0.38 & 0.10 & 0.10 & 0.09 & 0.24 & 0.20 & 0.01 & 0.003 & 0.04 & 0.04 \\
\hline W10 & US+ & 1.98 & 4.82 & 0.37 & 0.42 & 0.08 & 0.35 & 0.21 & 0.69 & 0.01 & 0.003 & 0.04 & 0.04 \\
\hline W12 & $\begin{array}{l}\text { N. Eur. + } \\
\text { N. Canada }\end{array}$ & 2.12 & 1.74 & 0.37 & 0.47 & 0.09 & 0.15 & 0.24 & 0.75 & 0.01 & 0.008 & 0.03 & 1.43 \\
\hline W13 & Europe + & 2.06 & 2.57 & 0.27 & 1.12 & 0.08 & 0.19 & 0.17 & 0.80 & 0.01 & 0.003 & 0.04 & 0.02 \\
\hline W14 & East Indies & 2.15 & 1.21 & 0.38 & 0.16 & 0.10 & 0.02 & 0.24 & 0.01 & 0.01 & 0.013 & 0.03 & 0.13 \\
\hline IND & India & 2.30 & 1.52 & 0.46 & 0.07 & 0.12 & 0.01 & 0.25 & 0.20 & 0.01 & 0.008 & 0.05 & 0.00 \\
\hline $\mathrm{CHI}$ & China & 2.17 & 1.90 & 0.37 & 0.38 & 0.09 & 0.12 & 0.29 & 0.03 & 0.01 & 0.029 & 0.04 & 0.01 \\
\hline JAP & Japan & 2.14 & 1.16 & 0.37 & 0.21 & 0.10 & 0.09 & 0.24 & 0.19 & 0.01 & 0.027 & 0.04 & 0.06 \\
\hline $\begin{array}{l}\text { North } \\
\text { America }\end{array}$ & $\begin{array}{l}\text { North } \\
\text { America }\end{array}$ & 1.98 & 4.82 & 0.37 & 0.42 & 0.08 & 0.35 & 0.21 & 0.69 & 0.012 & 0.003 & 0.04 & 0.04 \\
\hline $\begin{array}{l}\text { Latin } \\
\text { America }\end{array}$ & $\begin{array}{l}\text { Latin } \\
\text { America }\end{array}$ & 1.91 & 4.24 & 0.38 & 0.24 & 0.09 & 0.15 & 0.23 & 0.27 & 0.012 & 0.003 & 0.03 & 0.08 \\
\hline Europe & Europe & 2.06 & 2.57 & 0.27 & 1.12 & 0.08 & 0.19 & 0.17 & 0.80 & 0.012 & 0.003 & 0.04 & 0.02 \\
\hline $\begin{array}{l}\text { Africa }+ \\
\text { Middle } \\
\text { East }\end{array}$ & $\begin{array}{l}\text { Africa }+ \\
\text { Middle East }\end{array}$ & 2.34 & 0.99 & 0.35 & 0.45 & 0.11 & 0.03 & 0.27 & 0.09 & 0.012 & 0.006 & 0.04 & 0.02 \\
\hline $\begin{array}{l}\text { Central } \\
\text { Asia }\end{array}$ & Central Asia & 2.13 & 1.71 & 0.37 & 0.33 & 0.10 & 0.08 & 0.24 & 0.26 & 0.011 & 0.011 & 0.04 & 0.05 \\
\hline $\begin{array}{l}\text { Southeast } \\
\text { Asia }\end{array}$ & Southeast Asia & 2.56 & 1.76 & 0.56 & 0.21 & 0.14 & 0.06 & 0.40 & 0.10 & 0.005 & 0.017 & 0.05 & 0.02 \\
\hline $\begin{array}{l}\text { Northern } \\
\text { regions }\end{array}$ & $\begin{array}{l}\text { Northern } \\
\text { regions }\end{array}$ & 2.12 & 1.74 & 0.37 & 0.47 & 0.09 & 0.15 & 0.24 & 0.75 & 0.011 & 0.008 & 0.03 & 1.43 \\
\hline Oceania & Oceania & 2.09 & 9.21 & 0.37 & 0.21 & 0.09 & 0.59 & & 2.65 & 0.011 & 0.005 & 0.03 & \\
\hline & & $\begin{array}{l}\text { Recalculated } \\
\text { based on } \\
\text { continental } \\
\text { data }\end{array}$ & $\begin{array}{l}\text { FAO } \\
\text { production } \\
\text { data from } \\
2001\end{array}$ & $\begin{array}{l}\text { Recalculated } \\
\text { based on } \\
\text { continental } \\
\text { data }\end{array}$ & $\begin{array}{l}\text { FAO } \\
\text { production } \\
\text { data from } \\
2001\end{array}$ & $\begin{array}{l}\text { Recalculated } \\
\text { based on } \\
\text { continental } \\
\text { data }\end{array}$ & $\begin{array}{l}\text { FAO } \\
\text { production } \\
\text { data from } \\
2001\end{array}$ & $\begin{array}{l}\text { Recalculated } \\
\text { based } \\
\text { on continental } \\
\text { data }\end{array}$ & $\begin{array}{l}\text { FAO } \\
\text { production } \\
\text { data from } \\
2001\end{array}$ & $\begin{array}{l}\text { Recalculated } \\
\text { based on } \\
\text { continental } \\
\text { data }\end{array}$ & FAO FishSTAT & $\begin{array}{l}\text { Recalculated } \\
\text { based on } \\
\text { continental } \\
\text { data }\end{array}$ & FAO FishSTAT \\
\hline
\end{tabular}


Table B1

Chemical data of the set of 36 pollutants of the OMNIITOX set (Margni et al., 2002).

\begin{tabular}{|c|c|c|c|c|c|c|c|c|c|c|c|c|c|c|c|}
\hline Name & CAS & \multicolumn{2}{|c|}{$\begin{array}{l}\text { Degradable } \\
\text { with } \mathrm{H} \text { and } \\
\text { Kow }=0 \text {; } \\
\text { non-degradable } \\
\text { or specification } \\
\text { of partitioning } \\
\text { coefficients }=1\end{array}$} & $\begin{array}{l}\text { Molecular } \\
\text { mass } \\
(\mathrm{g} / \mathrm{mol})\end{array}$ & $\begin{array}{l}\text { Henry's } \\
\text { constant } \\
\left(\text { Pa m }^{3}\right. \\
\left.\text { mol }^{-1}\right) \\
\text { or Kaw }\end{array}$ & $\begin{array}{l}\text { Log } \\
\text { Kow }\end{array}$ & $\begin{array}{l}\text { Tropospheric } \\
\text { degradation } \\
\text { half life } \\
\text { (hours) }\end{array}$ & $\begin{array}{l}\text { Water- } \\
\text { column } \\
\text { degradation } \\
\text { half life } \\
\text { (hours) }\end{array}$ & $\begin{array}{l}\text { Soil surface layer } \\
\text { degradation } \\
\text { half life } \\
\text { (hours) }\end{array}$ & er & $\begin{array}{l}\text { Sediment } \\
\text { degradation } \\
\text { half life } \\
\text { (hours) }\end{array}$ & $\begin{array}{l}\text { Vegetation } \\
\text { degradation } \\
\text { half life } \\
\text { (hours) }\end{array}$ & $\begin{array}{l}\text { SOIL root } \\
\text { zone } \\
\text { degradation } \\
\text { half life } \\
\text { (hours) }\end{array}$ & $\begin{array}{l}\text { Soil vadose } \\
\text { layer } \\
\text { degradation } \\
\text { half life } \\
\text { (hours) }\end{array}$ & Source \\
\hline Tetrachloroethylene & $127-18-4$ & 0 & & 166 & $1.77 \mathrm{E}+03$ & 2.88 & $5.50 \mathrm{E}+02$ & $1.75 \mathrm{E}+03$ & $1.70 \mathrm{E}+03$ & OMNITOX & $5.50 \mathrm{E}+03$ & $1.70 \mathrm{E}+03$ & $1.70 \mathrm{E}+03$ & $1.70 \mathrm{E}+03$ & MACKAY \\
\hline $\begin{array}{l}\text { Carbon tetrachloride } \\
\text { (CCl4) }\end{array}$ & $56-23-5$ & 0 & & 154 & $2.76 \mathrm{E}+03$ & 2.64 & $1.70 \mathrm{E}+04$ & $1.70 \mathrm{E}+03$ & $6.04 \mathrm{E}+03$ & OMNITOX & $1.70 \mathrm{E}+04$ & $5.50 \mathrm{E}+03$ & $5.50 \mathrm{E}+03$ & $5.50 \mathrm{E}+03$ & MACKAY \\
\hline 1,3-Butadiene & 106-99-0 & 0 & & 54 & $7.36 \mathrm{E}+03$ & 1.99 & $1.70 \mathrm{E}+04$ & $1.70 \mathrm{E}+02$ & $5.50 \mathrm{E}+02$ & OMNITOX & $1.70 \mathrm{E}+03$ & $5.50 \mathrm{E}+02$ & $5.50 \mathrm{E}+02$ & $5.50 \mathrm{E}+02$ & MACKAY \\
\hline Methomyl & $16752-77-5$ & 0 & & 162 & $1.84 \mathrm{E}-05$ & 0.60 & $5.80 \mathrm{E}+01$ & $5.52 \mathrm{E}+03$ & $5.03 E+02$ & OMNITOX & $5.04 \mathrm{E}+02$ & $5.04 \mathrm{E}+02$ & $5.04 \mathrm{E}+02$ & $5.04 \mathrm{E}+02$ & USES \\
\hline Acephate & $30560-19-1$ & 0 & & 183 & $5.01 \mathrm{E}-08$ & -0.85 & $3.44 \mathrm{E}+01$ & $1.28 \mathrm{E}+03$ & $5.29 \mathrm{E}+01$ & OMNITOX & $5.28 \mathrm{E}+01$ & $5.28 \mathrm{E}+01$ & $5.28 \mathrm{E}+01$ & $5.28 \mathrm{E}+01$ & USES \\
\hline Formaldehyde & $50-00-0$ & 0 & & 30 & $3.37 \mathrm{E}-02$ & 0.35 & $3.63 E+00$ & $9.58 \mathrm{E}+01$ & $5.50 \mathrm{E}+01$ & OMNITOX & $3.84 \mathrm{E}+02$ & $9.60 \mathrm{E}+01$ & $9.60 \mathrm{E}+01$ & $9.60 \mathrm{E}+01$ & HOWARD \\
\hline PCBs & $1336-36-3$ & 0 & & 292 & $4.15 \mathrm{E}+01$ & 7.10 & $4.73 \mathrm{E}+02$ & $3.38 \mathrm{E}+02$ & $9.00 \mathrm{E}+02$ & OMNITOX & $1.34 \mathrm{E}+03$ & $3.36 \mathrm{E}+02$ & $3.36 \mathrm{E}+02$ & $3.36 \mathrm{E}+02$ & Estimate \\
\hline Di(n-octyl) phthalate & $117-84-0$ & 0 & & 391 & $2.57 \mathrm{E}-01$ & 8.10 & $1.87 \mathrm{E}+01$ & $3.36 \mathrm{E}+02$ & $3.37 \mathrm{E}+02$ & OMNITOX & $6.54 \mathrm{E}+03$ & $3.36 \mathrm{E}+02$ & $3.36 \mathrm{E}+02$ & $3.36 \mathrm{E}+02$ & USES \\
\hline Hexabromobenzene & $87-82-1$ & 0 & & 551 & $2.81 \mathrm{E}+00$ & 6.07 & $3.36 \mathrm{E}+04$ & $1.44 \mathrm{E}+03$ & $1.44 \mathrm{E}+03$ & OMNITOX & $5.76 \mathrm{E}+03$ & $1.44 \mathrm{E}+03$ & $1.44 \mathrm{E}+03$ & $1.44 \mathrm{E}+03$ & Estimate \\
\hline Cypermethrin & $52315-07-8$ & 0 & & 416 & $1.92 \mathrm{E}-02$ & 6.60 & $1.80 \mathrm{E}+01$ & $1.20 \mathrm{E}+02$ & $1.25 E+03$ & OMNITOX & $1.25 \mathrm{E}+03$ & $1.25 \mathrm{E}+03$ & $1.25 E+03$ & $1.25 \mathrm{E}+03$ & USES \\
\hline Mirex & $2385-85-5$ & 0 & & 546 & $8.11 \mathrm{E}+01$ & 6.90 & $1.70 \mathrm{E}+02$ & $1.70 \mathrm{E}+02$ & $5.50 \mathrm{E}+04$ & OMNITOX & $5.50 \mathrm{E}+04$ & $5.50 \mathrm{E}+04$ & $5.50 \mathrm{E}+04$ & $5.50 \mathrm{E}+04$ & MACKAY \\
\hline Triffluralin & 1582-09-8 & 0 & & 336 & $1.03 E+01$ & 5.34 & $1.70 \mathrm{E}+02$ & $1.70 \mathrm{E}+03$ & $1.70 \mathrm{E}+03$ & OMNITOX & $5.50 \mathrm{E}+03$ & $1.70 \mathrm{E}+03$ & $1.70 \mathrm{E}+03$ & $1.70 \mathrm{E}+03$ & MACKAY \\
\hline Dicofol & $115-32-2$ & 0 & & 370 & $2.42 \mathrm{E}-02$ & 5.02 & $1.12 \mathrm{E}+02$ & $9.00 \mathrm{E}+02$ & $1.46 \mathrm{E}+03$ & OMNITOX & $3.84 \mathrm{E}+02$ & $1.46 \mathrm{E}+03$ & $1.46 \mathrm{E}+03$ & $1.46 \mathrm{E}+03$ & CALTOX \\
\hline 1,4-Dichlorobenzene & $106-46-7$ & 0 & & 147 & $2.41 \mathrm{E}+02$ & 3.40 & $5.50 \mathrm{E}+02$ & $1.70 \mathrm{E}+03$ & $5.50 \mathrm{E}+03$ & OMNITOX & $1.70 \mathrm{E}+04$ & $5.50 \mathrm{E}+03$ & $5.50 \mathrm{E}+03$ & $5.50 \mathrm{E}+03$ & MACKAY \\
\hline Aldrin & $309-00-2$ & 0 & & 365 & $4.40 \mathrm{E}+00$ & 3.01 & $4.99 \mathrm{E}+00$ & $1.75 E+04$ & $1.70 \mathrm{E}+04$ & OMNITOX & $5.50 \mathrm{E}+04$ & $1.70 \mathrm{E}+04$ & $1.70 \mathrm{E}+04$ & $1.70 \mathrm{E}+04$ & MACKAY \\
\hline 1,1,2,2-Tetrachloroethane & $79-34-5$ & 0 & & 168 & $3.67 \mathrm{E}+01$ & 2.39 & $1.70 \mathrm{E}+04$ & $1.70 \mathrm{E}+03$ & $5.50 \mathrm{E}+03$ & OMNITOX & $1.70 \mathrm{E}+04$ & $5.50 \mathrm{E}+03$ & $5.50 \mathrm{E}+03$ & $5.50 \mathrm{E}+03$ & MACKAY \\
\hline Captan & $133-06-2$ & 0 & & 301 & $6.48 \mathrm{E}-04$ & 2.30 & $1.70 \mathrm{E}+01$ & $1.70 \mathrm{E}+01$ & $5.50 \mathrm{E}+02$ & OMNITOX & $5.50 \mathrm{E}+02$ & $5.50 \mathrm{E}+02$ & $5.50 \mathrm{E}+02$ & $5.50 \mathrm{E}+02$ & MACKAY \\
\hline Pronamide & $23950-58-5$ & 0 & & 256 & $9.77 \mathrm{E}-04$ & 3.43 & $2.91 \mathrm{E}+01$ & $9.77 \mathrm{E}+02$ & $1.93 \mathrm{E}+03$ & OMNITOX & $1.80 \mathrm{E}+02$ & $1.93 \mathrm{E}+03$ & $1.93 E+03$ & $1.93 \mathrm{E}+03$ & CALTOX \\
\hline Anthracene & $120-12-7$ & 0 & & 178 & $5.56 \mathrm{E}+00$ & 4.54 & $5.50 \mathrm{E}+01$ & $5.50 \mathrm{E}+02$ & $5.50 \mathrm{E}+03$ & OMNITOX & $1.70 \mathrm{E}+04$ & $5.50 \mathrm{E}+03$ & $5.50 \mathrm{E}+03$ & $5.50 \mathrm{E}+03$ & MACKAY \\
\hline Gamma-HCH (lindane) & 58-89-9 & 0 & & 291 & $5.14 \mathrm{E}-01$ & 3.70 & $1.04 \mathrm{E}+03$ & $1.70 \mathrm{E}+04$ & $1.70 \mathrm{E}+04$ & OMNITOX & $5.50 \mathrm{E}+04$ & $1.70 \mathrm{E}+04$ & $1.70 \mathrm{E}+04$ & $1.70 \mathrm{E}+04$ & MACKAY \\
\hline Dimethylphthalate (DMP) & $131-11-3$ & 0 & & 194 & $1.05 \mathrm{E}-02$ & 2.12 & $1.70 \mathrm{E}+02$ & $1.70 \mathrm{E}+02$ & $5.50 \mathrm{E}+02$ & OMNITOX & $1.70 \mathrm{E}+03$ & $5.50 \mathrm{E}+02$ & $5.50 \mathrm{E}+02$ & $5.50 \mathrm{E}+02$ & MACKAY \\
\hline Methanol & $67-56-1$ & 0 & & 32 & $4.55 \mathrm{E}-01$ & -0.77 & $3.92 \mathrm{E}+02$ & $5.50 \mathrm{E}+01$ & $5.50 \mathrm{E}+01$ & OMNITOX & $7.20 \mathrm{E}+01$ & $9.60 \mathrm{E}+01$ & $9.60 \mathrm{E}+01$ & $9.60 \mathrm{E}+01$ & HOWARD \\
\hline 1,2-Dichloroethane & $107-06-2$ & 0 & & 99 & $1.18 \mathrm{E}+02$ & 1.48 & $1.70 \mathrm{E}+03$ & $1.70 \mathrm{E}+03$ & $5.50 \mathrm{E}+03$ & OMNITOX & $1.70 \mathrm{E}+04$ & $5.50 \mathrm{E}+03$ & $5.50 \mathrm{E}+03$ & $5.50 \mathrm{E}+03$ & MACKAY \\
\hline Ethyl acetate & $141-78-6$ & 0 & & 88 & $1.34 \mathrm{E}+01$ & 0.73 & $1.94 \mathrm{E}+02$ & $9.58 \mathrm{E}+01$ & $1.70 \mathrm{E}+02$ & OMNITOX & $3.84 \mathrm{E}+02$ & $9.60 \mathrm{E}+01$ & $9.60 \mathrm{E}+01$ & $9.60 \mathrm{E}+01$ & HOWARD \\
\hline N-nitrosodiethylamine & $55-18-5$ & 0 & & 102 & 3.63E-01 & 0.48 & $6.00 \mathrm{E}+00$ & $6.00 \mathrm{E}+00$ & $1.70 \mathrm{E}+03$ & OMNITOX & $2.40 \mathrm{E}+01$ & $2.40 \mathrm{E}+03$ & $2.40 \mathrm{E}+03$ & $2.40 \mathrm{E}+03$ & HOWARD \\
\hline Thiram & $137-26-8$ & 0 & & 240 & $3.04 \mathrm{E}-02$ & 1.73 & $1.70 \mathrm{E}+02$ & $1.70 \mathrm{E}+02$ & $5.50 \mathrm{E}+02$ & OMNITOX & $1.70 \mathrm{E}+03$ & $5.50 \mathrm{E}+02$ & $5.50 \mathrm{E}+02$ & $5.50 \mathrm{E}+02$ & MACKAY \\
\hline Propoxur & $114-26-1$ & 0 & & 209 & $1.43 \mathrm{E}-04$ & 1.50 & $5.00 \mathrm{E}+00$ & $5.50 \mathrm{E}+02$ & $5.50 \mathrm{E}+02$ & OMNITOX & $1.70 \mathrm{E}+03$ & $5.50 \mathrm{E}+02$ & $5.50 \mathrm{E}+02$ & $5.50 \mathrm{E}+02$ & MACKAY \\
\hline Folpet & $133-07-3$ & 0 & & 297 & $7.66 \mathrm{E}-03$ & 2.85 & $2.45 \mathrm{E}+01$ & $1.38 \mathrm{E}+04$ & $1.38 \mathrm{E}+04$ & OMNITOX & $1.38 \mathrm{E}+04$ & $1.38 \mathrm{E}+04$ & $1.38 \mathrm{E}+04$ & $1.38 \mathrm{E}+04$ & USES \\
\hline Benomyl & $17804-35-2$ & 0 & & 290 & $4.93 \mathrm{E}-07$ & 2.30 & $4.99 \mathrm{E}+00$ & $1.70 \mathrm{E}+02$ & $1.70 \mathrm{E}+03$ & OMNITOX & $5.50 \mathrm{E}+03$ & $1.70 \mathrm{E}+03$ & $1.70 \mathrm{E}+03$ & $1.70 \mathrm{E}+03$ & MACKAY \\
\hline Hexachlorobutadiene & 87-68-3 & 0 & & 261 & $1.03 E+03$ & 4.78 & $1.28 \mathrm{E}+04$ & $1.75 E+03$ & $1.70 \mathrm{E}+03$ & OMNITOX & $1.70 \mathrm{E}+03$ & $1.70 \mathrm{E}+03$ & $1.70 \mathrm{E}+03$ & $1.70 \mathrm{E}+03$ & USES \\
\hline Hexachlorocyclopentadiene & $77-47-4$ & 0 & & 273 & $2.70 \mathrm{E}+03$ & 5.04 & $9.77 \mathrm{E}+02$ & $8.63 \mathrm{E}+01$ & $4.20 \mathrm{E}+02$ & OMNITOX & $1.68 \mathrm{E}+03$ & $4.20 \mathrm{E}+02$ & $4.20 \mathrm{E}+02$ & $4.20 \mathrm{E}+02$ & HOWARD \\
\hline Heptachlor epoxide & $1024-57-3$ & 0 & & 389 & $2.10 \mathrm{E}+00$ & 4.98 & $7.43 E+01$ & $7.03 E+03$ & $7.03 E+03$ & OMNITOX & $9.60 \mathrm{E}+01$ & $7.02 \mathrm{E}+03$ & $7.02 \mathrm{E}+03$ & $7.02 \mathrm{E}+03$ & HOWARD \\
\hline Hexachlorobenzene & $118-74-1$ & 0 & & 285 & $1.70 \mathrm{E}+02$ & 5.50 & $7.35 \mathrm{E}+03$ & $5.50 \mathrm{E}+04$ & $5.50 \mathrm{E}+04$ & OMNITOX & $5.50 \mathrm{E}+04$ & $5.50 \mathrm{E}+04$ & $5.50 \mathrm{E}+04$ & $5.50 \mathrm{E}+04$ & MACKAY \\
\hline Heptachlor & $76-44-8$ & 0 & & 373 & $2.94 \mathrm{E}+01$ & 5.27 & $5.50 \mathrm{E}+01$ & $5.50 \mathrm{E}+02$ & $1.70 \mathrm{E}+03$ & OMNITOX & $5.50 \mathrm{E}+03$ & $1.70 \mathrm{E}+03$ & $1.70 \mathrm{E}+03$ & $1.70 \mathrm{E}+03$ & MACKAY \\
\hline Nitrobenzene & $98-95-3$ & 0 & & 123 & 2.4 & 1.85 & $4.94 \mathrm{E}+00$ & $1.75 E+03$ & $1.23 E+03$ & OMNITOX & $5.50 \mathrm{E}+03$ & $1.70 \mathrm{E}+03$ & $1.70 \mathrm{E}+03$ & $1.70 \mathrm{E}+03$ & MACKAY \\
\hline Endosulfan & $115-29-7$ & 0 & & 407 & 6.5 & 3.83 & $3.85 \mathrm{E}+01$ & $1.13 \mathrm{E}+02$ & $2.11 \mathrm{E}+02$ & OMNITOX & $7.68 \mathrm{E}+02$ & $1.11 \mathrm{E}+02$ & $1.11 \mathrm{E}+02$ & $1.11 \mathrm{E}+02$ & HOWARD \\
\hline Name & РКа & $\begin{array}{l}\text { BCF } \\
\text { (kg-water/ } \\
\text { kg-fish) }\end{array}$ & $\begin{array}{l}\text { Chemical c } \\
\text { (optional) }\end{array}$ & & $\begin{array}{l}\text { Water - } \\
\text { top - surface } \\
\text { layer } \\
\text { degradation } \\
\text { half life } \\
\text { (hours) }\end{array}$ & $\begin{array}{l}\text { Water - } \\
\text { bottom - } \\
\text { deep sea } \\
\text { degradation } \\
\text { half life } \\
\text { (hours) }\end{array}$ & $\begin{array}{l}\text { Sediment } \\
\text { (anaerobic) } \\
\text { degradation } \\
\text { half life } \\
\text { (hours) }\end{array}$ & $\begin{array}{l}\text { BCF } \\
\text { (kg-water/ } \\
\text { kg-fish) }\end{array}$ & $\begin{array}{l}\text { ED10 - oral - } \\
\text { non-cancer } \\
\text { (mg/kg body } \\
\text { weight - day, } \\
\text { median } \\
\text { estimate) }\end{array}$ & $\begin{array}{l}\mathrm{ED} 10- \\
\text { inhalation - } \\
\text { non-cancer } \\
\text { (mg/kg body } \\
\text { weight - day, } \\
\text { median estimate) }\end{array}$ & $\begin{array}{l}\text { DALY/ } \\
\text { incidence - } \\
\text { oral - non- } \\
\text { cancer }\end{array}$ & $\begin{array}{l}\text { DALY/ } \\
\text { incidence - } \\
\text { inhalation - } \\
\text { non-cancer }\end{array}$ & $\begin{array}{l}\text { ED10 - oral - } \\
\text { cancer (mg/kg } \\
\text { body weight - } \\
\text { day, median } \\
\text { estimate) }\end{array}$ & $\begin{array}{l}\text { ED10 - } \\
\text { inhalation - } \\
\text { cancer (mg/kg } \\
\text { body weight - } \\
\text { day, median } \\
\text { estimate) }\end{array}$ & $\begin{array}{l}\text { Aquatic } \\
\text { ecotoxicological } \\
\text { effect factor } \\
\text { (PAF per } \mathrm{kg} / \mathrm{m}^{3} \text {, } \\
\text { median } \\
\text { estimate) }\end{array}$ \\
\hline Tetrachloroethylene & & $8.28 \mathrm{E}+01$ & $\begin{array}{l}\text { Non-disso } \\
\text { compound }\end{array}$ & & $5.50 \mathrm{E}+02$ & $5.50 \mathrm{E}+03$ & $5.50 \mathrm{E}+03$ & $8.28 \mathrm{E}+01$ & $5.26 \mathrm{E}-01$ & $2.08 \mathrm{E}+00$ & $1.30 \mathrm{E}+00$ & $1.30 \mathrm{E}+00$ & $4.00 \mathrm{E}+00$ & & $6.13 \mathrm{E}+02$ \\
\hline Carbon tetrachloride ( $\mathrm{CCl} 4)$ & & $3.01 \mathrm{E}+01$ & $\begin{array}{l}\text { Non-disso } \\
\text { compound }\end{array}$ & & $1.70 \mathrm{E}+03$ & $1.70 \mathrm{E}+04$ & $1.70 \mathrm{E}+04$ & $3.01 \mathrm{E}+01$ & $5.38 \mathrm{E}-02$ & $4.09 \mathrm{E}+00$ & $1.30 \mathrm{E}+00$ & $1.30 \mathrm{E}+00$ & $1.19 \mathrm{E}+00$ & $1.19 \mathrm{E}+00$ & $6.73 \mathrm{E}+01$ \\
\hline
\end{tabular}




\begin{tabular}{|c|c|c|c|c|c|c|c|c|c|c|c|c|c|c|}
\hline Name & PKa & $\begin{array}{l}\text { BCF } \\
\text { (kg-water/ } \\
\text { kg-fish) }\end{array}$ & $\begin{array}{l}\text { Chemical class } \\
\text { (optional) }\end{array}$ & $\begin{array}{l}\text { Water - } \\
\text { top - surface } \\
\text { layer } \\
\text { degradation } \\
\text { half life } \\
\text { (hours) }\end{array}$ & $\begin{array}{l}\text { Water - } \\
\text { bottom - } \\
\text { deep sea } \\
\text { degradation } \\
\text { half life } \\
\text { (hours) }\end{array}$ & $\begin{array}{l}\text { Sediment } \\
\text { (anaerobic) } \\
\text { degradation } \\
\text { half life } \\
\text { (hours) }\end{array}$ & $\begin{array}{l}\text { BCF } \\
\text { (kg-water/ } \\
\text { kg-fish) }\end{array}$ & $\begin{array}{l}\text { ED10 - oral - } \\
\text { non-cancer } \\
\text { (mg/kg body } \\
\text { weight - day, } \\
\text { median } \\
\text { estimate) }\end{array}$ & $\begin{array}{l}\text { ED10 - } \\
\text { inhalation - } \\
\text { non-cancer } \\
\text { (mg/kg body } \\
\text { weight - day, } \\
\text { median estimate) }\end{array}$ & $\begin{array}{l}\text { DALY/ } \\
\text { incidence - } \\
\text { oral - non- } \\
\text { cancer }\end{array}$ & $\begin{array}{l}\text { DALY/ } \\
\text { incidence - } \\
\text { inhalation - } \\
\text { non-cancer }\end{array}$ & $\begin{array}{l}\text { ED10 - oral - } \\
\text { cancer ( } \mathrm{mg} / \mathrm{kg} \\
\text { body weight - } \\
\text { day, median } \\
\text { estimate) }\end{array}$ & $\begin{array}{l}\text { ED10 - } \\
\text { inhalation - } \\
\text { cancer }(\mathrm{mg} / \mathrm{kg} \\
\text { body weight - } \\
\text { day, median } \\
\text { estimate) }\end{array}$ & $\begin{array}{l}\text { Aquatic } \\
\text { ecotoxicological } \\
\text { effect factor } \\
\text { (PAF per kg/m } \mathrm{m}^{3} \text {, } \\
\text { median } \\
\text { estimate) }\end{array}$ \\
\hline 1,3-Butadiene & & $6.80 \mathrm{E}+00$ & $\begin{array}{l}\text { Non-dissociating } \\
\text { compound }\end{array}$ & $1.70 \mathrm{E}+02$ & $1.70 \mathrm{E}+03$ & $1.70 \mathrm{E}+03$ & $6.80 \mathrm{E}+00$ & $6.76 \mathrm{E}-01$ & $6.76 \mathrm{E}-01$ & $1.30 \mathrm{E}+00$ & $1.30 \mathrm{E}+00$ & & $1.04 \mathrm{E}+01$ & $2.01 \mathrm{E}+02$ \\
\hline Methomyl & & $3.16 \mathrm{E}+00$ & $\begin{array}{l}\text { Non-dissociating } \\
\text { compound }\end{array}$ & $5.52 \mathrm{E}+03$ & $5.04 \mathrm{E}+02$ & $5.04 \mathrm{E}+02$ & $3.16 \mathrm{E}+00$ & $2.50 \mathrm{E}+00$ & & $1.30 \mathrm{E}+00$ & $1.30 \mathrm{E}+00$ & & & $7.01 E+03$ \\
\hline Acephate & & $3.16 \mathrm{E}+00$ & $\begin{array}{l}\text { Non-dissociating } \\
\text { compound }\end{array}$ & $1.26 \mathrm{E}+03$ & $5.28 \mathrm{E}+01$ & $5.28 \mathrm{E}+01$ & $3.16 \mathrm{E}+00$ & $2.04 \mathrm{E}-03$ & & $1.30 \mathrm{E}+00$ & $1.30 \mathrm{E}+00$ & $1.00 \mathrm{E}+01$ & & $7.26 \mathrm{E}+01$ \\
\hline Formaldehyde & $1.33 \mathrm{E}+01$ & $3.16 \mathrm{E}+00$ & $\begin{array}{l}\text { Non-dissociating } \\
\text { compound }\end{array}$ & $9.60 \mathrm{E}+01$ & $3.84 \mathrm{E}+02$ & $3.84 \mathrm{E}+02$ & $3.16 \mathrm{E}+00$ & $3.75 \mathrm{E}+00$ & $2.52 \mathrm{E}-03$ & $1.30 \mathrm{E}+00$ & $1.30 \mathrm{E}+00$ & & $9.09 \mathrm{E}-02$ & $7.42 \mathrm{E}+01$ \\
\hline PCBs & & $5.80 \mathrm{E}+04$ & $\begin{array}{l}\text { Mixture (of non- } \\
\text { dissociating } \\
\text { compounds) }\end{array}$ & $3.36 \mathrm{E}+02$ & $1.34 \mathrm{E}+03$ & $1.34 \mathrm{E}+03$ & $5.80 \mathrm{E}+04$ & & & $1.30 \mathrm{E}+00$ & $1.30 \mathrm{E}+00$ & & & $7.50 \mathrm{E}+05$ \\
\hline Di(n-octyl) phthalate & & $6.35 \mathrm{E}+01$ & $\begin{array}{l}\text { Non-dissociating } \\
\text { compound }\end{array}$ & $3.36 \mathrm{E}+02$ & $6.54 \mathrm{E}+03$ & $6.54 \mathrm{E}+03$ & $6.35 \mathrm{E}+01$ & $3.09 \mathrm{E}+00$ & & $1.30 \mathrm{E}+00$ & $1.30 \mathrm{E}+00$ & & & $1.50 \mathrm{E}+01$ \\
\hline Hexabromobenzene & & $9.42 \mathrm{E}+03$ & $\begin{array}{l}\text { Non-dissociating } \\
\text { compound }\end{array}$ & $1.44 \mathrm{E}+03$ & $5.76 \mathrm{E}+03$ & $5.76 \mathrm{E}+03$ & $9.42 \mathrm{E}+03$ & $1.61 \mathrm{E}-01$ & & $1.30 \mathrm{E}+00$ & $1.30 \mathrm{E}+00$ & & & $1.45 \mathrm{E}+06$ \\
\hline Cypermethrin & & $2.07 \mathrm{E}+02$ & $\begin{array}{l}\text { Non-dissociating } \\
\text { compound }\end{array}$ & $1.20 \mathrm{E}+02$ & $1.25 \mathrm{E}+03$ & $1.25 \mathrm{E}+03$ & $2.07 \mathrm{E}+02$ & $1.00 \mathrm{E}+00$ & & $1.30 \mathrm{E}+00$ & $1.30 \mathrm{E}+00$ & & & $6.47 \mathrm{E}+06$ \\
\hline Mirex & & $4.03 E+04$ & $\begin{array}{l}\text { Non-dissociating } \\
\text { compound }\end{array}$ & $1.70 \mathrm{E}+02$ & $5.50 \mathrm{E}+04$ & $5.50 \mathrm{E}+04$ & $4.03 E+04$ & $1.85 \mathrm{E}-02$ & & $1.30 \mathrm{E}+00$ & $1.30 \mathrm{E}+00$ & $7.14 \mathrm{E}-02$ & & $3.33 \mathrm{E}+03$ \\
\hline Trifluralin & & $2.58 \mathrm{E}+03$ & $\begin{array}{l}\text { Non-dissociating } \\
\text { compound }\end{array}$ & $1.70 \mathrm{E}+03$ & $5.50 \mathrm{E}+03$ & $5.50 \mathrm{E}+03$ & $2.58 \mathrm{E}+03$ & $7.69 \mathrm{E}-01$ & & $1.30 \mathrm{E}+00$ & $1.30 \mathrm{E}+00$ & $2.94 \mathrm{E}+01$ & & $1.13 \mathrm{E}+04$ \\
\hline Dicofol & & $1.46 \mathrm{E}+03$ & $\begin{array}{l}\text { Hydrolyses app t }{ }_{1 / 2} \text { : } \\
120 \mathrm{~h} \text { (Bulle et al.) }\end{array}$ & $8.99 \mathrm{E}+02$ & $3.84 \mathrm{E}+02$ & $3.84 \mathrm{E}+02$ & $1.46 \mathrm{E}+03$ & & & $1.30 \mathrm{E}+00$ & $1.30 \mathrm{E}+00$ & $1.32 \mathrm{E}+00$ & & $1.03 E+04$ \\
\hline 1,4-Dichlorobenzene & & $8.89 \mathrm{E}+01$ & $\begin{array}{l}\text { Non-dissociating } \\
\text { compound }\end{array}$ & $1.70 \mathrm{E}+03$ & $1.70 \mathrm{E}+04$ & $1.70 \mathrm{E}+04$ & $8.89 \mathrm{E}+01$ & $2.03 \mathrm{E}+00$ & $7.69 \mathrm{E}+01$ & $1.30 \mathrm{E}+00$ & $1.30 \mathrm{E}+00$ & $2.56 \mathrm{E}+01$ & & $7.63 E+02$ \\
\hline Aldrin & & $2.02 E+04$ & $\begin{array}{l}\text { Non-dissociating } \\
\text { compound }\end{array}$ & $1.70 \mathrm{E}+04$ & $5.50 \mathrm{E}+04$ & $5.50 \mathrm{E}+04$ & $2.02 \mathrm{E}+04$ & $1.25 \mathrm{E}-03$ & & $1.30 \mathrm{E}+00$ & $1.30 \mathrm{E}+00$ & $1.18 \mathrm{E}-02$ & $1.18 \mathrm{E}-02$ & $8.27 \mathrm{E}+04$ \\
\hline 1,1,2,2-Tetrachloroethane & & $1.38 \mathrm{E}+01$ & $\begin{array}{l}\text { Non-dissociating } \\
\text { compound }\end{array}$ & $1.70 \mathrm{E}+03$ & $1.70 \mathrm{E}+04$ & $1.70 \mathrm{E}+04$ & $1.38 \mathrm{E}+01$ & $2.15 E+00$ & $2.32 \mathrm{E}+01$ & $1.30 \mathrm{E}+00$ & $1.30 \mathrm{E}+00$ & $1.54 \mathrm{E}+00$ & $9.09 \mathrm{E}-01$ & $2.83 \mathrm{E}+02$ \\
\hline Captan & & $2.86 \mathrm{E}+01$ & $\begin{array}{l}\text { Non-dissociating } \\
\text { compound }\end{array}$ & $1.70 \mathrm{E}+01$ & $5.50 \mathrm{E}+02$ & $5.50 \mathrm{E}+02$ & $2.86 \mathrm{E}+01$ & $3.33 \mathrm{E}+00$ & & $1.30 \mathrm{E}+00$ & $1.30 \mathrm{E}+00$ & & & $7.21 \mathrm{E}+03$ \\
\hline Pronamide & & $8.73 E+01$ & $\begin{array}{l}\text { Non-dissociating } \\
\text { compound }\end{array}$ & $9.79 E+02$ & $1.80 \mathrm{E}+02$ & $1.80 \mathrm{E}+02$ & $8.73 \mathrm{E}+01$ & $7.69 \mathrm{E}+00$ & & $1.30 \mathrm{E}+00$ & $1.30 \mathrm{E}+00$ & $4.76 \mathrm{E}+00$ & & $3.66 \mathrm{E}+02$ \\
\hline Anthracene & & $5.33 \mathrm{E}+02$ & $\begin{array}{l}\text { Non-dissociating } \\
\text { compound }\end{array}$ & $5.50 \mathrm{E}+02$ & $1.70 \mathrm{E}+04$ & $1.70 \mathrm{E}+04$ & $5.33 \mathrm{E}+02$ & $3.70 \mathrm{E}+01$ & & $1.30 \mathrm{E}+00$ & $1.30 \mathrm{E}+00$ & & & $3.92 \mathrm{E}+04$ \\
\hline Gamma-HCH (lindane) & & $3.08 \mathrm{E}+02$ & $\begin{array}{l}\text { Non-dissociating } \\
\text { compound }\end{array}$ & $1.70 \mathrm{E}+04$ & $5.50 \mathrm{E}+04$ & $5.50 \mathrm{E}+04$ & $3.08 \mathrm{E}+02$ & $2.63 \mathrm{E}-02$ & $1.16 \mathrm{E}-01$ & $1.30 \mathrm{E}+00$ & $1.30 \mathrm{E}+00$ & $1.23 \mathrm{E}+00$ & & $2.85 \mathrm{E}+04$ \\
\hline Dimethylphthalate (DMP) & & $3.40 \mathrm{E}+00$ & $\begin{array}{l}\text { Non-dissociating } \\
\text { compound }\end{array}$ & $1.70 \mathrm{E}+02$ & $1.70 \mathrm{E}+03$ & $1.70 \mathrm{E}+03$ & $3.40 \mathrm{E}+00$ & & & $1.30 \mathrm{E}+00$ & $1.30 \mathrm{E}+00$ & & & $4.14 \mathrm{E}+01$ \\
\hline Methanol & $1.53 \mathrm{E}+01$ & $3.16 \mathrm{E}+00$ & & $5.50 \mathrm{E}+01$ & $7.20 \mathrm{E}+01$ & $7.20 \mathrm{E}+01$ & $3.16 \mathrm{E}+00$ & $3.79 E+01$ & & $1.30 \mathrm{E}+00$ & $1.30 \mathrm{E}+00$ & & & $1.50 \mathrm{E}+00$ \\
\hline 1,2-Dichloroethane & & $2.75 \mathrm{E}+00$ & $\begin{array}{l}\text { Non-dissociating } \\
\text { compound }\end{array}$ & $1.70 \mathrm{E}+03$ & $1.70 \mathrm{E}+04$ & $1.70 \mathrm{E}+04$ & $2.75 \mathrm{E}+00$ & $8.70 \mathrm{E}-01$ & $8.67 \mathrm{E}+01$ & $1.30 \mathrm{E}+00$ & $1.30 \mathrm{E}+00$ & $3.23 \mathrm{E}-01$ & $2.17 \mathrm{E}+00$ & $2.57 \mathrm{E}+01$ \\
\hline
\end{tabular}




\begin{tabular}{|c|c|c|c|c|c|c|c|c|c|c|c|c|c|c|}
\hline Ethyl acetate & & $3.16 \mathrm{E}+00$ & $\begin{array}{l}\text { Non-dissociating } \\
\text { compound }\end{array}$ & $9.60 \mathrm{E}+01$ & $3.84 \mathrm{E}+02$ & $3.84 \mathrm{E}+02$ & $3.16 \mathrm{E}+00$ & $7.14 \mathrm{E}+01$ & & $1.30 \mathrm{E}+00$ & $1.30 \mathrm{E}+00$ & & & $7.42 \mathrm{E}+00$ \\
\hline $\mathrm{N}$-nitrosodiethylamine & $3.89 \mathrm{E}+00$ & $3.16 \mathrm{E}+00$ & $\begin{array}{l}\text { Non-dissociating } \\
\text { compound }\end{array}$ & $6.00 \mathrm{E}+00$ & $2.40 \mathrm{E}+01$ & $2.40 \mathrm{E}+01$ & $3.16 \mathrm{E}+00$ & & & $1.30 \mathrm{E}+00$ & $1.30 \mathrm{E}+00$ & $9.09 \mathrm{E}-04$ & $1.33 \mathrm{E}-03$ & $6.00 \mathrm{E}+00$ \\
\hline Thiram & $8.70 E-01$ & $4.29 \mathrm{E}+00$ & & $1.70 \mathrm{E}+02$ & $1.70 \mathrm{E}+03$ & $1.70 \mathrm{E}+03$ & $4.29 \mathrm{E}+00$ & $1.33 \mathrm{E}+00$ & & $1.30 \mathrm{E}+00$ & $1.30 \mathrm{E}+00$ & & & $4.00 \mathrm{E}+04$ \\
\hline Propoxur & $1.19 \mathrm{E}+01$ & $2.95 \mathrm{E}+00$ & & $5.50 \mathrm{E}+02$ & $1.70 \mathrm{E}+03$ & $1.70 \mathrm{E}+03$ & $2.95 \mathrm{E}+00$ & $3.23 \mathrm{E}-02$ & & $1.30 \mathrm{E}+00$ & $1.30 \mathrm{E}+00$ & & & $3.21 \mathrm{E}+03$ \\
\hline Folpet & & $3.12 \mathrm{E}+01$ & $\begin{array}{l}\text { Non-dissociating } \\
\text { compound }\end{array}$ & $1.38 \mathrm{E}+04$ & $1.38 \mathrm{E}+04$ & $1.38 \mathrm{E}+04$ & $3.12 \mathrm{E}+01$ & $1.00 \mathrm{E}+01$ & & $1.30 \mathrm{E}+00$ & $1.30 \mathrm{E}+00$ & $4.17 \mathrm{E}+01$ & & $8.07 \mathrm{E}+03$ \\
\hline Benomyl & & $8.56 \mathrm{E}+00$ & Significant hydrolysis & $1.70 \mathrm{E}+02$ & $5.50 \mathrm{E}+03$ & $5.50 \mathrm{E}+03$ & $8.56 \mathrm{E}+00$ & $1.33 E+00$ & & $1.30 \mathrm{E}+00$ & $1.30 E+00$ & & & $1.31 \mathrm{E}+03$ \\
\hline Hexachlorobutadiene & & $9.56 \mathrm{E}+02$ & $\begin{array}{l}\text { Non-dissociating } \\
\text { compound }\end{array}$ & $1.70 \mathrm{E}+03$ & $1.70 \mathrm{E}+03$ & $1.70 \mathrm{E}+03$ & $9.56 \mathrm{E}+02$ & $1.40 \mathrm{E}-03$ & $1.14 \mathrm{E}+00$ & $1.30 \mathrm{E}+00$ & $1.30 \mathrm{E}+00$ & $2.94 \mathrm{E}+00$ & $2.94 \mathrm{E}+00$ & $5.82 \mathrm{E}+03$ \\
\hline Hexachlorocyclopentadiene & & $1.52 \mathrm{E}+03$ & $\begin{array}{l}\text { Hydrolyses app } t_{1 / 2} \text { : } \\
173 \mathrm{~h} \text { (Bulle et al.) }\end{array}$ & $8.65 \mathrm{E}+01$ & $1.68 \mathrm{E}+03$ & $1.68 \mathrm{E}+03$ & $1.52 \mathrm{E}+03$ & $5.56 \mathrm{E}-01$ & $1.80 \mathrm{E}-03$ & $1.30 \mathrm{E}+00$ & $1.30 \mathrm{E}+00$ & & & $4.38 \mathrm{E}+04$ \\
\hline Heptachlor epoxide & & $1.36 \mathrm{E}+03$ & $\begin{array}{l}\text { Non-dissociating } \\
\text { compound }\end{array}$ & $7.02 \mathrm{E}+03$ & $9.60 \mathrm{E}+01$ & $9.60 \mathrm{E}+01$ & $1.36 \mathrm{E}+03$ & $2.33 \mathrm{E}-03$ & & $1.30 \mathrm{E}+00$ & $1.30 \mathrm{E}+00$ & $2.17 E-02$ & $2.17 \mathrm{E}-02$ & $1.66 \mathrm{E}+05$ \\
\hline Hexachlorobenzene & & $5.15 \mathrm{E}+03$ & $\begin{array}{l}\text { Non-dissociating } \\
\text { compound }\end{array}$ & $5.50 \mathrm{E}+04$ & $5.50 \mathrm{E}+04$ & $5.50 \mathrm{E}+04$ & $5.15 \mathrm{E}+03$ & $2.13 \mathrm{E}-02$ & $1.50 \mathrm{E}-05$ & $1.30 \mathrm{E}+00$ & $1.30 \mathrm{E}+00$ & $7.69 \mathrm{E}-02$ & 7.69E -02 & $2.16 \mathrm{E}+04$ \\
\hline Heptachlor & & $9.93 E+03$ & $\begin{array}{l}\text { Hydrolyses app } \mathrm{t}_{1 / 2}: \\
23.1 \mathrm{~h} \text { (Bulle et al.) }\end{array}$ & $5.50 \mathrm{E}+02$ & $5.50 \mathrm{E}+03$ & $5.50 \mathrm{E}+03$ & $9.93 \mathrm{E}+03$ & $4.00 \mathrm{E}-02$ & & $1.30 \mathrm{E}+00$ & $1.30 \mathrm{E}+00$ & $4.76 \mathrm{E}-02$ & $4.35 \mathrm{E}-02$ & $1.02 \mathrm{E}+05$ \\
\hline Nitrobenzene & & $5.30 \mathrm{E}+00$ & & $1.70 \mathrm{E}+03$ & $5.50 \mathrm{E}+03$ & $5.50 \mathrm{E}+03$ & $5.30 \mathrm{E}+00$ & $3.23 \mathrm{E}-02$ & & $1.30 \mathrm{E}+00$ & $1.30 \mathrm{E}+00$ & & & \\
\hline Endosulfan & & $1.78 E+02$ & & $1.11 \mathrm{E}+02$ & $7.68 \mathrm{E}+02$ & $7.68 \mathrm{E}+02$ & $1.78 \mathrm{E}+02$ & $1.59 \mathrm{E}-01$ & & $1.30 \mathrm{E}+00$ & $1.30 \mathrm{E}+00$ & & & $2.65 \mathrm{E}+05$ \\
\hline
\end{tabular}




\section{Appendix C. Additional USEtox parameterization results}

Fig. C. 1 compares the freshwater residence times (fate factors) for 14 chemicals emitted in each sub-continent, in the a-spatial USEtox model and the spatially differentiated IMPACTWorld model. It is similar to Fig. $2 \mathrm{~b}$, but with results differentiated by substance and for a restricted number of substances.

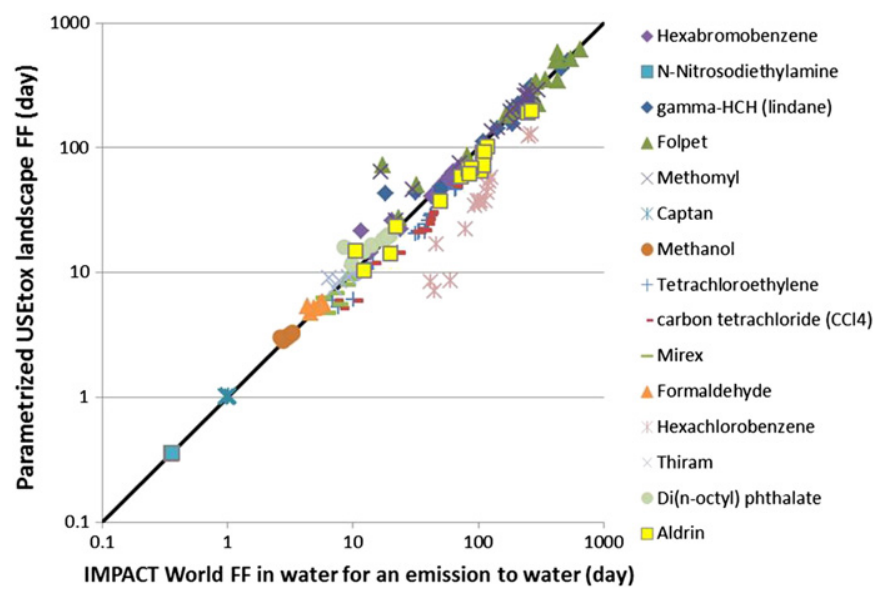

Fig. C.1. Comparison between a-spatial USEtox model and the spatially differentiated IMPACTWorld model predictions of freshwater residence time (fate factor, FF) for 14 chemicals emitted in each sub-continent.
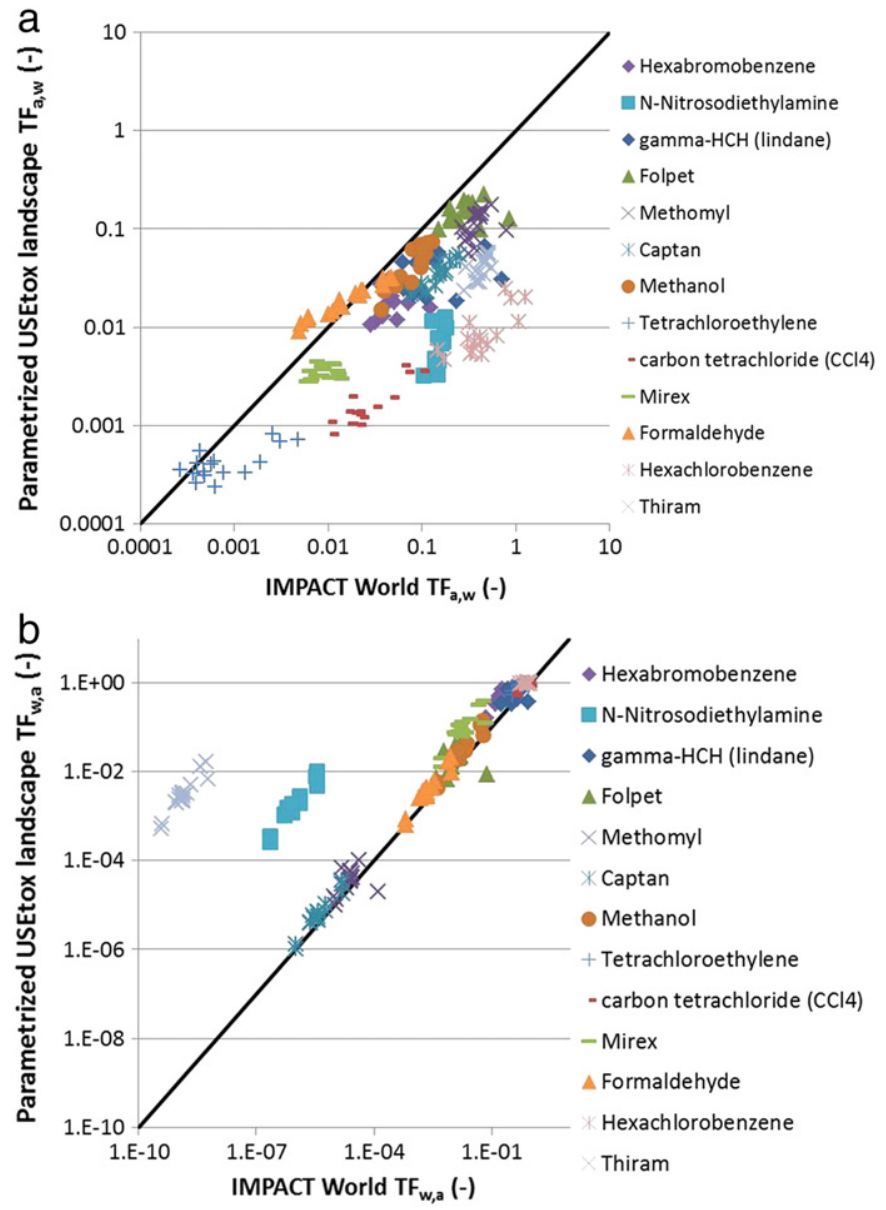

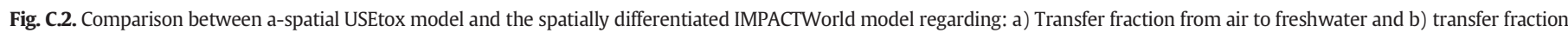
from freshwater to air. 
We calculated transfer fractions from air to freshwater ( $T F_{a, w}$, unitless) and from freshwater to air ( $T F_{w, a}$, unitless) based on the following fate factors:

$T F_{a, w}=\frac{F F_{a, w}}{F F_{w, w}}$

$T F_{w, a}=\frac{F F_{w, a}}{F F_{a, a}}$

where all the fate factors (FF) are in units of days and equal to the steady state substance mass in the second subscript (in kg) for an emission flow of $1 \mathrm{~kg} /$ day to the compartment indicated by the first subscript. $F F_{a, w}$ is the fate factor in freshwater for an emission to air, $F F_{w, a}$ is the fate factor in air for an emission to freshwater (days), $F F_{w, w}$ is the fate for an emission to freshwater in freshwater (days), and $F F_{a, a}$ is the fate factor in air for an emission to air (days).

Fig. C.2a shows that for many pollutants, IMPACTWorld overestimates the transfer factor from air to freshwater by about one order of magnitude compared to USEtox. The dominant disappearance pathway of pollutants with high $\mathrm{K}_{\mathrm{H}}$ (e.g., hexachlorobenzene $\mathrm{K}_{\mathrm{H}}=170 \mathrm{~Pa} \cdot \mathrm{m}^{3} \cdot \mathrm{mol}^{-1}$, $\mathrm{carbon} \mathrm{tet}-$ rachloride $\mathrm{K}_{\mathrm{H}}=2760 \mathrm{~Pa} \cdot \mathrm{m}^{3} \cdot \mathrm{mol}^{-1}$, and n-nitrosodiethylamine $\mathrm{K}_{\mathrm{H}}=0.362 \mathrm{~Pa} \cdot \mathrm{m}^{3} \cdot \mathrm{mol}^{-1}$ ) emitted to continental air is transfer to global air.

The transfer factor from air to freshwater is higher than 1.0 for hexachlorobenzene in IMPACTWorld for emission to Brazil (W8) and East Indies (W14). This result is in line with Fig. 2b results, where the fate of hexachlorobenzene in W14 is observed to exceed the freshwater residence time in this sub-continental zone due to a transfer to Antarctica (W11). In the same way, when hexachlorobenzene is emitted to air in East Indies and Brazil, it is transported to Antarctica where the freshwater residence time is higher than in East Indies and Brazil (>8000 years compared to 19 days and 34 days). Hexachlorobenzene fate in water when emitted to air is thus higher than when emitted in water in W8 and W14, due to a transfer to Antarctica and important substance residence time there.

Fig. C.2b shows that when emitted to freshwater, the thiram and n-nitrosodiethylamine transfer fractions to air are under-estimated by USEtox by six and three orders of magnitude, respectively.

Based on these observations, deviations in fate results are more due to model algorithm differences (i.e., modelling of freshwater outflow and the volatilization algorithm) than to the influence of surrounding global or continental zones.

Figs. C.3 and C.4 present respectively intake fractions for an emission to freshwater and for an emission to air. Fig. C.3a shows that results for both models are aligned except for thiram and n-nitrosodiethylamine. This difference is correlated with the discrepancies observed for transfer fraction from freshwater to air (see Fig. C.2b), and thus due to a difference in fate factor $\mathrm{F}_{\mathrm{w}, \mathrm{a}}$.
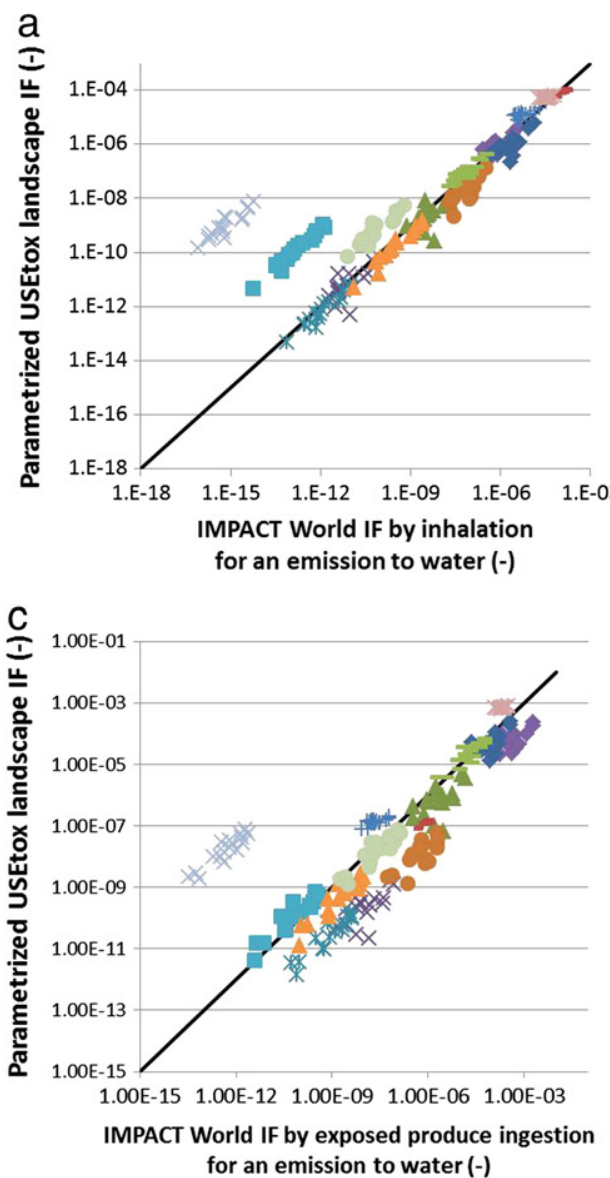

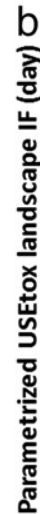

Di(n-octyl) phthalate

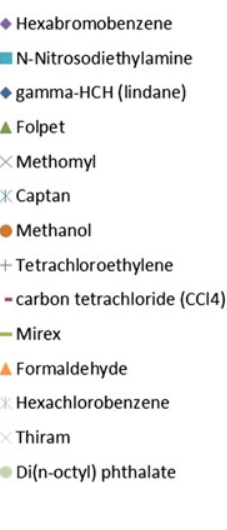

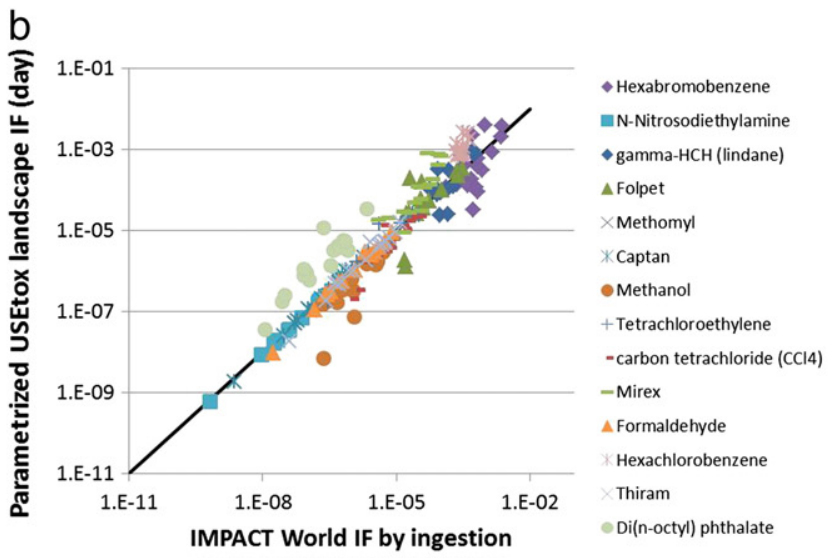

for an emission to water (-)

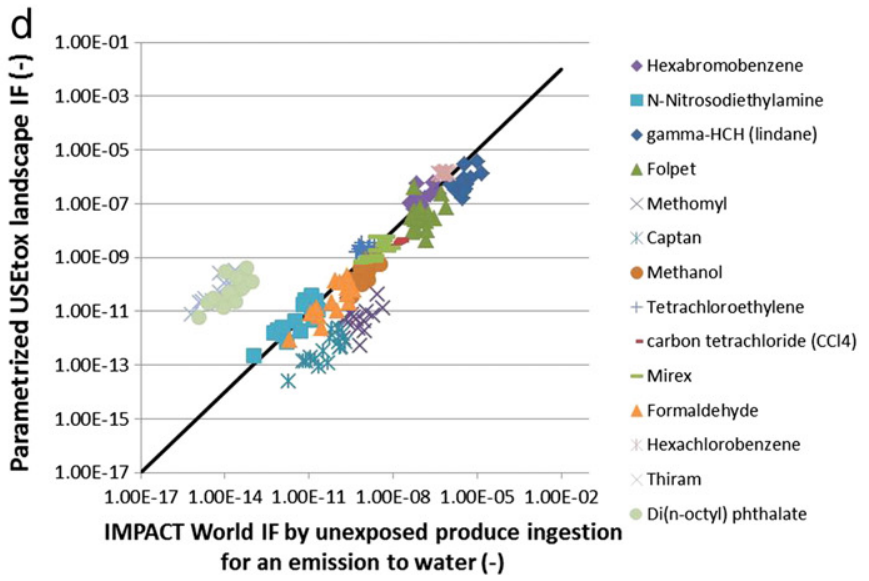

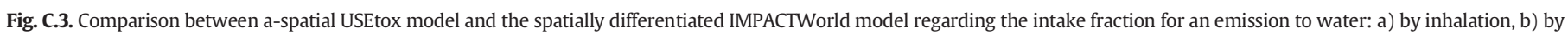
total ingestion, c) by exposed produce ingestion, and d) by unexposed produce ingestion. 

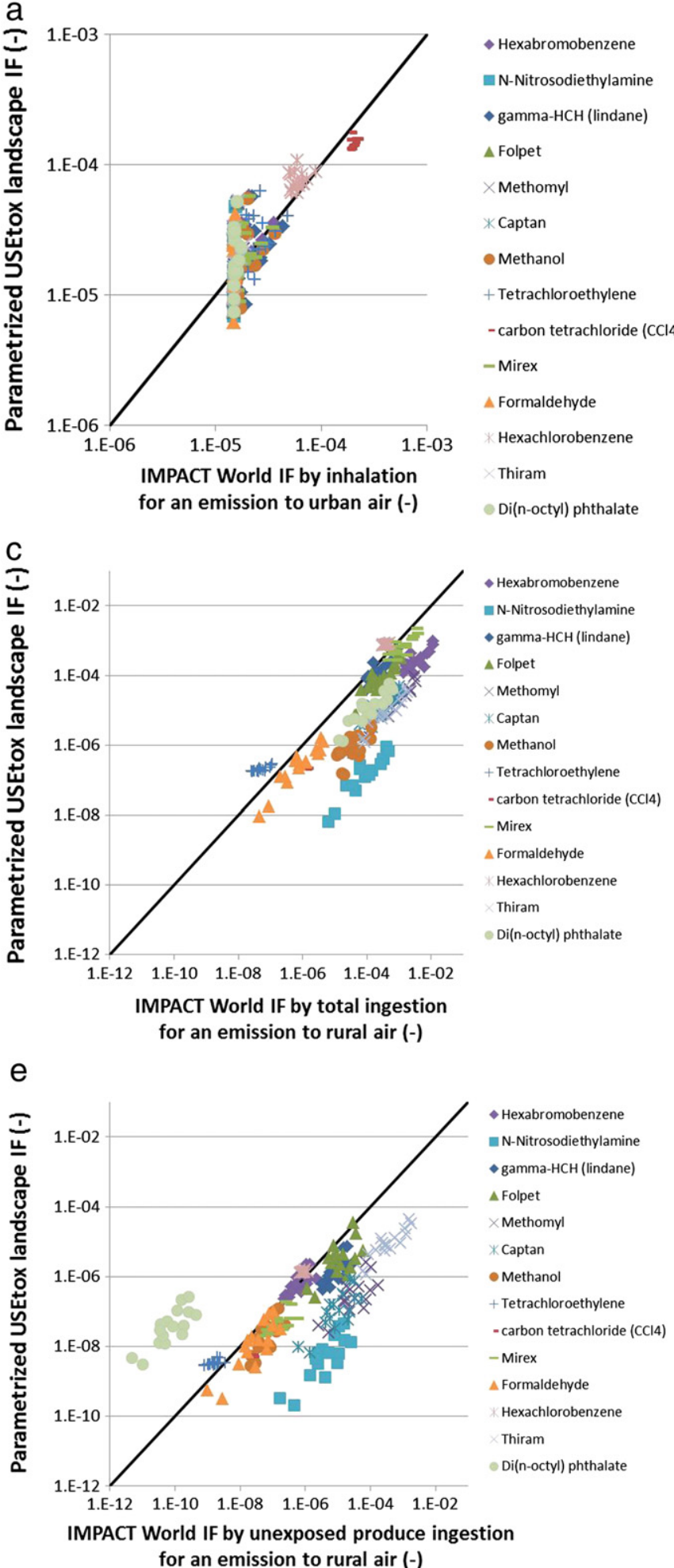

Di(n-octyl) phthalate

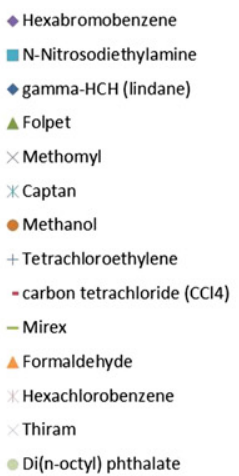

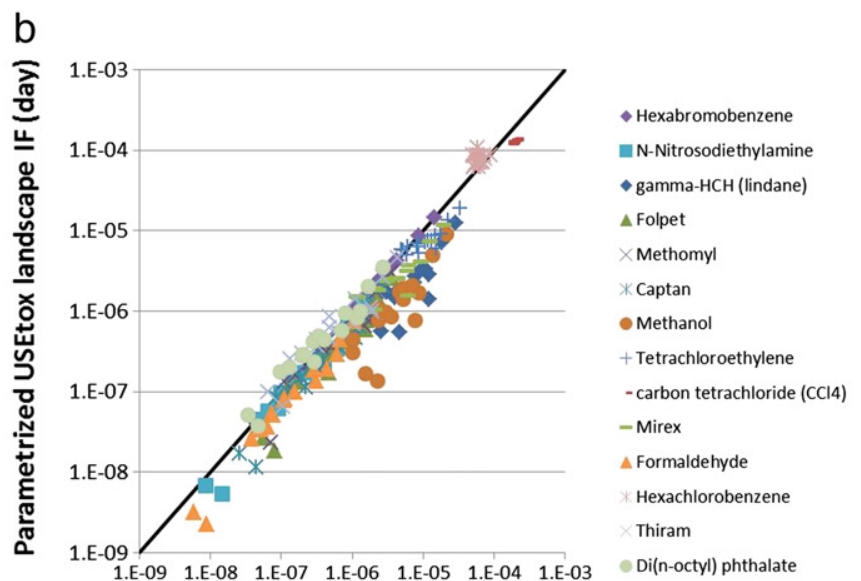

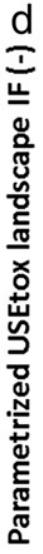

IMPACT World IF by inhalation for an emission to rural air (-)
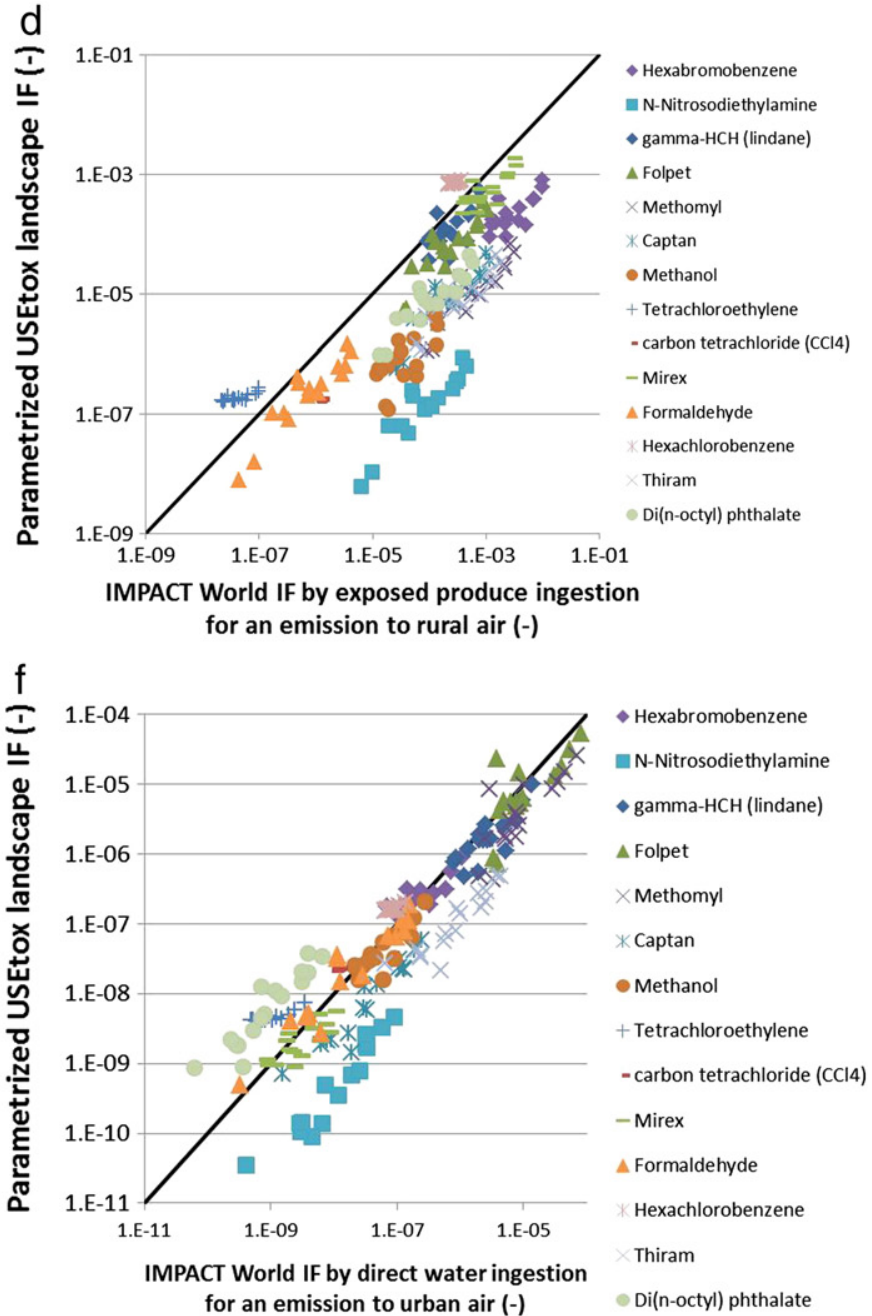

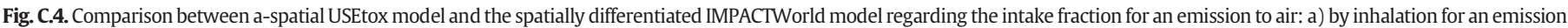

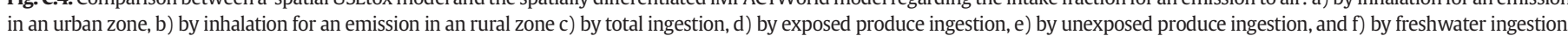

\section{Appendix D. Landscape data for USEtox parameterization}

Fig. D.1a presents the variability in intake fraction through water ingestion across European watersheds, as calculated by the spatially differentiated European model for emissions in each of the European watersheds, as a function of the chemical degradation half-life in freshwater. In contrast to the variation of fate, the intake fraction varies by up to five orders of magnitude for quickly degraded pollutants with half-lives shorter than a day, 
such as n-nitrosodiethylamine ( $\mathrm{t}_{1 / 2}=6 \mathrm{~h}$ in freshwater). On the contrary, the intake fraction through freshwater ingestion varies by three to four orders of magnitude for persistent pollutants with half-lives larger than 100 days, such as methomyl $\left(t_{1 / 2}=230\right.$ days in freshwater).

By displaying the intake fraction through water ingestion as a function of the freshwater residence time for four pollutants with different persistence in freshwater ( $\mathrm{n}$-nitrosodiethylamine $\mathrm{t}_{1 / 2}=0.25 \mathrm{~d}$, captan: $\mathrm{t}_{1 / 2}=0.71 \mathrm{~d}$, hexabromobenzene: $\mathrm{t}_{1 / 2}=73 \mathrm{~d}$, and methomyl: $\mathrm{t}_{1 / 2}=230 \mathrm{~d}$ ), Fig. D.1b shows that the variability across watershed decreases as water residence time increases, more prominently for quickly degraded pollutants. In short-residence-time watersheds, all substances are equally ingested through drinking water independently of their persistence (persistent substances are removed from the system by advection). In long-residence-time watersheds, the intake fraction of n-nitrosodiethylamine is up to 4 orders of magnitude lower than in short-residence-time watersheds. This is explained by the fact that low persistence substances are degraded in watersheds where they have been emitted, where the population is generally lower than for watersheds close to the coast (population is the only spatially differentiated parameter affecting exposure by water ingestion). This variability is reduced to three orders of magnitude for methomyl, given that this substance crosses watersheds with various population patterns due to its high persistence.

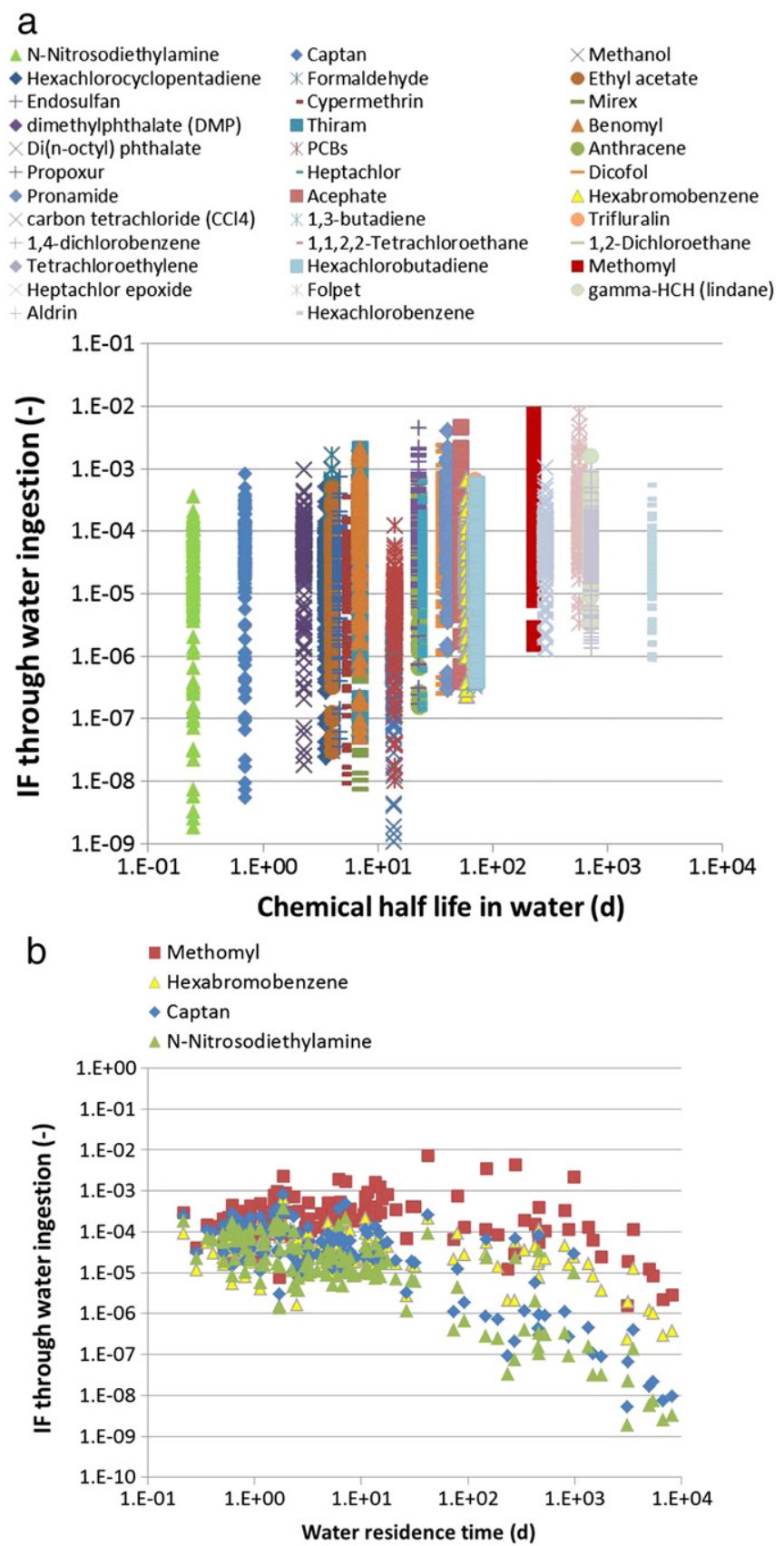

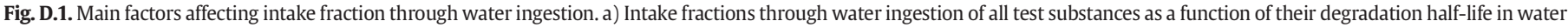

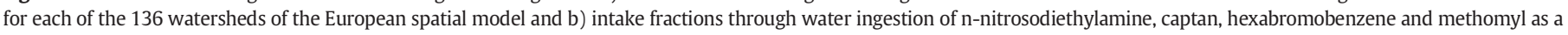
function of water residence time to sea for each of the 136 watershed of the European spatial model. 


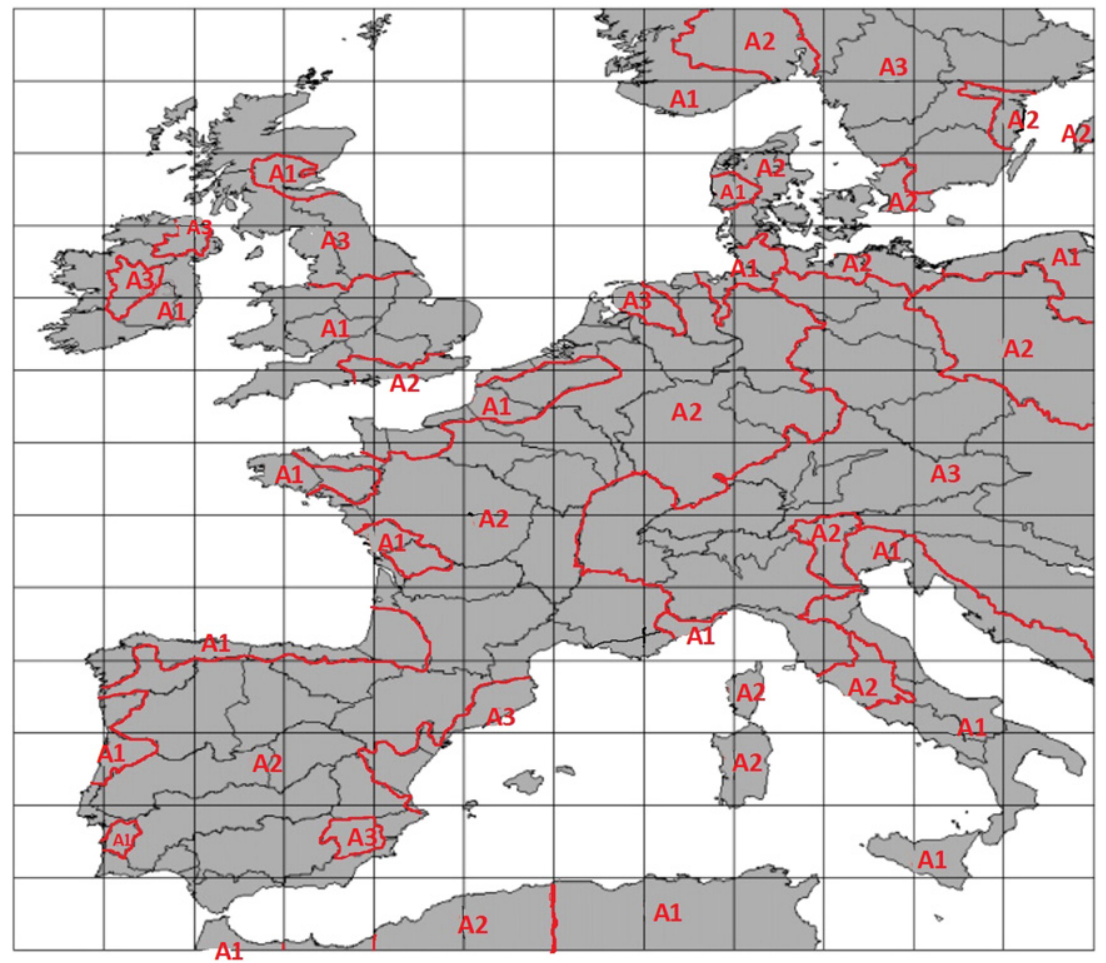

Fig. E.1. Boundaries of the three archetypical watershed A1, A2 and A3 models based on IMPACT Europe spatial model (Pennington et al., 2005).

Table E.1

Classification of IMPACT Europe spatial model watersheds into A1, A2 and A3 archetype categories.

\begin{tabular}{|c|c|c|c|c|c|c|c|}
\hline Region no. & $\begin{array}{l}\text { Volume } \\
\left(\mathrm{m}^{3}\right)\end{array}$ & $\begin{array}{l}\text { Advection rate } \\
\left(\mathrm{m}^{3} / \mathrm{h}\right)\end{array}$ & $\begin{array}{l}\text { Is there a watershed } \\
\text { after this one }\end{array}$ & $\begin{array}{l}\text { Retention in } \\
\text { watershed (d) }\end{array}$ & $\begin{array}{l}\text { Retention after } \\
\text { watershed (d) }\end{array}$ & $\begin{array}{l}\text { Retention time } \\
\text { until the sea }(\mathrm{d})\end{array}$ & $\begin{array}{l}\text { Archetype watershed } \\
\text { classification }\end{array}$ \\
\hline wo & $4.00 \mathrm{E}+13$ & $4.15 E+09$ & & $4.01 \mathrm{E}+02$ & & $4.01 \mathrm{E}+02$ & A0 \\
\hline W2 & $1.00 \mathrm{E}+08$ & $1.24 \mathrm{E}+06$ & & $3.39 \mathrm{E}+00$ & & $3.39 \mathrm{E}+00$ & $\mathrm{~A} 2$ \\
\hline W3 & $1.04 \mathrm{E}+07$ & $2.49 \mathrm{E}+05$ & & $1.74 \mathrm{E}+00$ & & $1.74 \mathrm{E}+00$ & $\mathrm{~A} 1$ \\
\hline W4 & $8.79 E+09$ & $8.15 \mathrm{E}+05$ & W4 & $4.50 \mathrm{E}+02$ & $8.83 \mathrm{E}+02$ & $1.33 \mathrm{E}+03$ & A3 \\
\hline W5 & $7.46 \mathrm{E}+10$ & $6.78 \mathrm{E}+06$ & W5 & $4.58 \mathrm{E}+02$ & $4.24 \mathrm{E}+02$ & $8.83 \mathrm{E}+02$ & A3 \\
\hline W6 & $6.63 E+07$ & $9.28 \mathrm{E}+05$ & & $2.98 \mathrm{E}+00$ & & $2.98 \mathrm{E}+00$ & A2 \\
\hline W7 & $9.76 \mathrm{E}+07$ & $1.47 \mathrm{E}+06$ & W7 & $2.77 \mathrm{E}+00$ & $3.15 \mathrm{E}+00$ & $5.92 \mathrm{E}+00$ & $\mathrm{~A} 2$ \\
\hline W8 & $1.43 E+08$ & $1.88 \mathrm{E}+06$ & & $3.15 \mathrm{E}+00$ & & $3.15 \mathrm{E}+00$ & $\mathrm{~A} 2$ \\
\hline W9 & $2.80 \mathrm{E}+07$ & $5.28 \mathrm{E}+05$ & & $2.21 \mathrm{E}+00$ & & $2.21 \mathrm{E}+00$ & A2 \\
\hline W10 & $1.90 \mathrm{E}+08$ & $2.04 \mathrm{E}+06$ & & $3.90 \mathrm{E}+00$ & & $3.90 \mathrm{E}+00$ & $\mathrm{~A} 2$ \\
\hline W11 & $8.89 \mathrm{E}+07$ & $8.80 \mathrm{E}+05$ & & $4.21 \mathrm{E}+00$ & & $4.21 \mathrm{E}+00$ & $\mathrm{~A} 2$ \\
\hline W12 & $9.41 \mathrm{E}+07$ & $5.88 \mathrm{E}+05$ & & $6.67 \mathrm{E}+00$ & & $6.67 \mathrm{E}+00$ & A2 \\
\hline W13 & $5.66 \mathrm{E}+06$ & $9.99 \mathrm{E}+04$ & & $2.36 \mathrm{E}+00$ & & $2.36 \mathrm{E}+00$ & $\mathrm{~A} 2$ \\
\hline W14 & $9.66 \mathrm{E}+07$ & $1.23 \mathrm{E}+06$ & W14 & $3.28 \mathrm{E}+00$ & $4.62 \mathrm{E}+00$ & $7.90 \mathrm{E}+00$ & $\mathrm{~A} 2$ \\
\hline W15 & $3.49 \mathrm{E}+08$ & $3.15 \mathrm{E}+06$ & & $4.62 \mathrm{E}+00$ & & $4.62 \mathrm{E}+00$ & A2 \\
\hline W16 & $1.22 \mathrm{E}+08$ & $1.04 \mathrm{E}+06$ & & $4.93 \mathrm{E}+00$ & & $4.93 \mathrm{E}+00$ & $\mathrm{~A} 2$ \\
\hline W17 & $7.92 \mathrm{E}+07$ & $1.43 \mathrm{E}+06$ & & $2.31 \mathrm{E}+00$ & & $2.31 \mathrm{E}+00$ & $\mathrm{~A} 2$ \\
\hline W18 & $1.39 \mathrm{E}+11$ & $1.60 \mathrm{E}+06$ & W18 & $3.62 \mathrm{E}+03$ & $1.76 \mathrm{E}+03$ & $5.38 \mathrm{E}+03$ & A3 \\
\hline W19 & $2.09 \mathrm{E}+11$ & $4.94 \mathrm{E}+06$ & & $1.76 \mathrm{E}+03$ & & $1.76 \mathrm{E}+03$ & A3 \\
\hline W20 & $1.31 \mathrm{E}+11$ & $3.71 \mathrm{E}+06$ & W20 & $1.48 \mathrm{E}+03$ & $7.18 \mathrm{E}+00$ & $1.48 \mathrm{E}+03$ & A3 \\
\hline W21 & $5.23 \mathrm{E}+07$ & $5.74 \mathrm{E}+05$ & W21 & $3.80 \mathrm{E}+00$ & $7.18 \mathrm{E}+00$ & $1.10 \mathrm{E}+01$ & $\mathrm{~A} 2$ \\
\hline W22 & $9.12 \mathrm{E}+08$ & $7.72 \mathrm{E}+06$ & W22 & $4.93 \mathrm{E}+00$ & $2.26 \mathrm{E}+00$ & $7.18 \mathrm{E}+00$ & $\mathrm{~A} 2$ \\
\hline W23 & $4.71 \mathrm{E}+08$ & $8.69 \mathrm{E}+06$ & & $2.26 \mathrm{E}+00$ & & $2.26 \mathrm{E}+00$ & A2 \\
\hline W24 & $1.06 \mathrm{E}+11$ & $9.15 E+05$ & W24 & $4.83 \mathrm{E}+03$ & $1.45 \mathrm{E}+02$ & $4.97 \mathrm{E}+03$ & A3 \\
\hline W25 & $1.39 \mathrm{E}+10$ & $4.04 \mathrm{E}+06$ & W25 & $1.43 \mathrm{E}+02$ & $2.57 \mathrm{E}+00$ & $1.45 \mathrm{E}+02$ & A3 \\
\hline W26 & $3.72 \mathrm{E}+08$ & $6.05 \mathrm{E}+06$ & & $2.57 \mathrm{E}+00$ & & $2.57 \mathrm{E}+00$ & A2 \\
\hline W27 & $1.90 \mathrm{E}+07$ & $4.81 \mathrm{E}+05$ & & $1.64 \mathrm{E}+00$ & & $1.64 \mathrm{E}+00$ & $\mathrm{~A} 1$ \\
\hline W28 & $1.65 \mathrm{E}+07$ & $4.59 \mathrm{E}+03$ & & $1.50 \mathrm{E}+02$ & & $1.50 \mathrm{E}+02$ & A3 \\
\hline W29 & $4.60 \mathrm{E}+07$ & $8.49 \mathrm{E}+05$ & W29 & $2.26 \mathrm{E}+00$ & $3.08 \mathrm{E}+00$ & $5.34 \mathrm{E}+00$ & $\mathrm{~A} 2$ \\
\hline W30 & $3.20 \mathrm{E}+07$ & $5.53 \mathrm{E}+05$ & W30 & $2.41 \mathrm{E}+00$ & $3.08 \mathrm{E}+00$ & $5.49 \mathrm{E}+00$ & $\mathrm{~A} 2$ \\
\hline W31 & $1.20 \mathrm{E}+08$ & $1.63 \mathrm{E}+06$ & & $3.08 \mathrm{E}+00$ & & $3.08 \mathrm{E}+00$ & $\mathrm{~A} 2$ \\
\hline
\end{tabular}


Table E.1 (continued)

\begin{tabular}{|c|c|c|c|c|c|c|c|}
\hline Region no. & $\begin{array}{l}\text { Volume } \\
\left(\mathrm{m}^{3}\right)\end{array}$ & $\begin{array}{l}\text { Advection rate } \\
\left(\mathrm{m}^{3} / \mathrm{h}\right)\end{array}$ & $\begin{array}{l}\text { Is there a watershed } \\
\text { after this one }\end{array}$ & $\begin{array}{l}\text { Retention in } \\
\text { watershed (d) }\end{array}$ & $\begin{array}{l}\text { Retention after } \\
\text { watershed }(d)\end{array}$ & $\begin{array}{l}\text { Retention time } \\
\text { until the sea (d) }\end{array}$ & $\begin{array}{l}\text { Archetype watershed } \\
\text { classification }\end{array}$ \\
\hline W32 & $1.23 \mathrm{E}+07$ & $2.08 \mathrm{E}+05$ & W32 & $2.46 \mathrm{E}+00$ & $4.72 \mathrm{E}+00$ & $7.18 \mathrm{E}+00$ & $\mathrm{~A} 2$ \\
\hline W33 & $1.96 \mathrm{E}+08$ & $1.73 \mathrm{E}+06$ & & $4.72 \mathrm{E}+00$ & & $4.72 \mathrm{E}+00$ & A2 \\
\hline W34 & $3.07 \mathrm{E}+06$ & $2.08 \mathrm{E}+05$ & & $6.16 \mathrm{E}-01$ & & $6.16 \mathrm{E}-01$ & $\mathrm{~A} 1$ \\
\hline W35 & $1.95 \mathrm{E}+08$ & $1.72 \mathrm{E}+06$ & & $4.72 \mathrm{E}+00$ & & $4.72 \mathrm{E}+00$ & $\mathrm{~A} 2$ \\
\hline W36 & $2.97 \mathrm{E}+06$ & $1.34 \mathrm{E}+05$ & & $9.24 \mathrm{E}-01$ & & $9.24 \mathrm{E}-01$ & $\mathrm{~A} 1$ \\
\hline W37 & $4.01 \mathrm{E}+07$ & $4.40 \mathrm{E}+05$ & W37 & $3.80 \mathrm{E}+00$ & $3.18 \mathrm{E}+00$ & $6.98 \mathrm{E}+00$ & $\mathrm{~A} 2$ \\
\hline W38 & $1.74 \mathrm{E}+08$ & $2.28 \mathrm{E}+06$ & & $3.18 \mathrm{E}+00$ & & $3.18 \mathrm{E}+00$ & A2 \\
\hline W39 & $7.71 \mathrm{E}+06$ & $3.91 \mathrm{E}+05$ & & $8.21 \mathrm{E}-01$ & & $8.21 \mathrm{E}-01$ & $\mathrm{~A} 1$ \\
\hline W40 & $8.74 \mathrm{E}+07$ & $3.18 \mathrm{E}+05$ & & $1.14 \mathrm{E}+01$ & & $1.14 \mathrm{E}+01$ & $\mathrm{~A} 2$ \\
\hline W41 & $1.28 \mathrm{E}+08$ & $4.53 \mathrm{E}+05$ & & $1.17 \mathrm{E}+01$ & & $1.17 \mathrm{E}++01$ & $\mathrm{~A} 2$ \\
\hline W42 & $1.95 \mathrm{E}+10$ & $2.30 \mathrm{E}+05$ & & $3.54 \mathrm{E}+03$ & & $3.54 \mathrm{E}+03$ & A3 \\
\hline W43 & $6.52 \mathrm{E}+07$ & $2.79 \mathrm{E}+03$ & & $9.75 \mathrm{E}+02$ & & $9.75 \mathrm{E}+02$ & A3 \\
\hline W44 & $3.27 \mathrm{E}+07$ & $1.18 \mathrm{E}+05$ & & $1.15 \mathrm{E}+01$ & & $1.15 \mathrm{E}+01$ & $\mathrm{~A} 2$ \\
\hline W45 & $7.70 \mathrm{E}+07$ & $1.51 \mathrm{E}+05$ & & $2.12 \mathrm{E}+01$ & & $2.12 \mathrm{E}+01$ & $\mathrm{~A} 2$ \\
\hline W46 & $7.86 \mathrm{E}+07$ & $2.09 \mathrm{E}+05$ & & $1.56 \mathrm{E}+01$ & & $1.56 \mathrm{E}+01$ & $\mathrm{~A} 2$ \\
\hline W47 & $1.24 \mathrm{E}+07$ & $2.93 \mathrm{E}+04$ & & $1.76 \mathrm{E}+01$ & & $1.76 \mathrm{E}+01$ & $\mathrm{~A} 2$ \\
\hline W48 & $1.70 \mathrm{E}+06$ & $1.15 \mathrm{E}+04$ & & $6.16 \mathrm{E}+00$ & & $6.16 \mathrm{E}+00$ & $\mathrm{~A} 2$ \\
\hline W49 & $3.31 \mathrm{E}+07$ & $1.19 \mathrm{E}+05$ & & $1.16 \mathrm{E}+01$ & & $1.16 \mathrm{E}+01$ & $\mathrm{~A} 2$ \\
\hline W50 & $3.01 \mathrm{E}+07$ & $9.79 \mathrm{E}+05$ & & $1.28 \mathrm{E}+00$ & & $1.28 \mathrm{E}+00$ & $\mathrm{~A} 1$ \\
\hline W51 & $1.58 \mathrm{E}+07$ & $7.11 \mathrm{E}+05$ & & $9.24 \mathrm{E}-01$ & & $9.24 \mathrm{E}-01$ & $\mathrm{~A} 1$ \\
\hline W52 & $3.02 \mathrm{E}+07$ & $1.06 \mathrm{E}+06$ & & $1.18 \mathrm{E}+00$ & & $1.18 \mathrm{E}+00$ & $\mathrm{~A} 1$ \\
\hline W53 & $2.19 \mathrm{E}+07$ & $1.37 \mathrm{E}+06$ & & $6.67 \mathrm{E}-01$ & & $6.67 \mathrm{E}-01$ & $\mathrm{~A} 1$ \\
\hline W54 & $6.36 \mathrm{E}+06$ & $7.38 \mathrm{E}+05$ & & $3.59 \mathrm{E}-01$ & & $3.59 \mathrm{E}-01$ & $\mathrm{~A} 1$ \\
\hline W55 & $4.86 \mathrm{E}+07$ & $1.23 \mathrm{E}+06$ & & $1.64 \mathrm{E}+00$ & & $1.64 \mathrm{E}+00$ & $\mathrm{~A} 1$ \\
\hline W56 & $3.03 E+07$ & $1.60 \mathrm{E}+05$ & & $7.87 \mathrm{E}+00$ & & $7.87 \mathrm{E}+00$ & $\mathrm{~A} 2$ \\
\hline W57 & $3.45 \mathrm{E}+06$ & $1.75 \mathrm{E}+05$ & & $8.21 \mathrm{E}-01$ & & $8.21 \mathrm{E}-01$ & $\mathrm{~A} 1$ \\
\hline W58 & $3.68 \mathrm{E}+07$ & $1.11 \mathrm{E}+05$ & & $1.38 \mathrm{E}+01$ & & $1.38 \mathrm{E}+01$ & A2 \\
\hline W59 & $6.32 \mathrm{E}+06$ & $3.21 \mathrm{E}+05$ & & $8.21 \mathrm{E}-01$ & & $8.21 \mathrm{E}-01$ & $\mathrm{~A} 1$ \\
\hline W60 & $1.99 \mathrm{E}+07$ & $9.87 \mathrm{E}+04$ & & $8.42 \mathrm{E}+00$ & & $8.42 \mathrm{E}+00$ & A2 \\
\hline W61 & $2.04 \mathrm{E}+06$ & $2.96 \mathrm{E}+05$ & & $2.87 \mathrm{E}-01$ & & $2.87 \mathrm{E}-01$ & $\mathrm{~A} 1$ \\
\hline W62 & $5.26 \mathrm{E}+06$ & $2.67 \mathrm{E}+05$ & & $8.21 \mathrm{E}-01$ & & $8.21 \mathrm{E}-01$ & $\mathrm{~A} 1$ \\
\hline W63 & $1.07 \mathrm{E}+06$ & $1.08 \mathrm{E}+05$ & & $4.10 \mathrm{E}-01$ & & $4.10 \mathrm{E}-01$ & $\mathrm{~A} 1$ \\
\hline W64 & $6.56 \mathrm{E}+06$ & $2.22 \mathrm{E}+05$ & & $1.23 \mathrm{E}+00$ & & $1.23 \mathrm{E}+00$ & $\mathrm{~A} 1$ \\
\hline W65 & $1.00 \mathrm{E}+07$ & $1.30 \mathrm{E}+05$ & & $3.21 \mathrm{E}+00$ & & $3.21 \mathrm{E}+00$ & A2 \\
\hline W66 & $6.78 \mathrm{E}+07$ & $2.10 \mathrm{E}+05$ & & $1.35 \mathrm{E}+01$ & & $1.35 \mathrm{E}+01$ & A2 \\
\hline W67 & $8.96 \mathrm{E}+08$ & $4.67 \mathrm{E}+05$ & & $7.99 \mathrm{E}+01$ & & $7.99 \mathrm{E}+01$ & A3 \\
\hline W68 & $9.46 \mathrm{E}+06$ & $1.51 \mathrm{E}+05$ & & $2.61 \mathrm{E}+00$ & & $2.61 \mathrm{E}+00$ & A2 \\
\hline W69 & $4.90 \mathrm{E}+06$ & $2.21 \mathrm{E}+05$ & & $9.24 \mathrm{E}-01$ & & $9.24 \mathrm{E}-01$ & $\mathrm{~A} 1$ \\
\hline W70 & $2.60 \mathrm{E}+06$ & $1.51 \mathrm{E}+05$ & & $7.18 \mathrm{E}-01$ & & $7.18 \mathrm{E}-01$ & $\mathrm{~A} 1$ \\
\hline W71 & $5.53 \mathrm{E}+06$ & $3.46 \mathrm{E}+05$ & & $6.67 \mathrm{E}-01$ & & $6.67 \mathrm{E}-01$ & $\mathrm{~A} 1$ \\
\hline W72 & $4.56 \mathrm{E}+07$ & $3.50 \mathrm{E}+05$ & & $5.43 \mathrm{E}+00$ & & $5.43 \mathrm{E}+00$ & $\mathrm{~A} 2$ \\
\hline W73 & $8.58 \mathrm{E}+06$ & $3.87 \mathrm{E}+05$ & & $9.24 \mathrm{E}-01$ & & $9.24 \mathrm{E}-01$ & $\mathrm{~A} 1$ \\
\hline W74 & $1.46 \mathrm{E}+08$ & $4.50 \mathrm{E}+05$ & & $1.35 \mathrm{E}+01$ & & $1.35 \mathrm{E}+01$ & A2 \\
\hline W75 & $7.17 \mathrm{E}+07$ & $3.39 \mathrm{E}+05$ & & $8.83 \mathrm{E}+00$ & & $8.83 \mathrm{E}+00$ & A2 \\
\hline W76 & $1.26 \mathrm{E}+08$ & $1.66 \mathrm{E}+05$ & & $3.16 \mathrm{E}+01$ & & $3.16 \mathrm{E}+01$ & $\mathrm{~A} 2$ \\
\hline W77 & $9.29 \mathrm{E}+07$ & $3.18 \mathrm{E}+05$ & & $1.22 \mathrm{E}+01$ & & $1.22 \mathrm{E}+01$ & A2 \\
\hline W78 & $9.47 \mathrm{E}+07$ & $2.58 \mathrm{E}+05$ & & $1.53 \mathrm{E}+01$ & & $1.53 \mathrm{E}+01$ & $\mathrm{~A} 2$ \\
\hline W79 & $7.64 \mathrm{E}+09$ & $9.19 \mathrm{E}+05$ & W79 & $3.46 \mathrm{E}+02$ & $4.59 \mathrm{E}+02$ & $8.05 E+02$ & A3 \\
\hline W80 & $1.46 \mathrm{E}+08$ & $2.20 \mathrm{E}+06$ & W80 & $2.77 \mathrm{E}+00$ & $4.56 \mathrm{E}+02$ & $4.59 \mathrm{E}+02$ & A3 \\
\hline W81 & $2.23 \mathrm{E}+10$ & $2.42 \mathrm{E}++06$ & W81 & $3.83 \mathrm{E}+02$ & $7.31 \mathrm{E}+01$ & $4.56 \mathrm{E}+02$ & A3 \\
\hline W82 & $4.79 \mathrm{E}+09$ & $2.73 \mathrm{E}+06$ & & $7.31 \mathrm{E}+01$ & & $7.31 \mathrm{E}+01$ & A3 \\
\hline W83 & $4.73 \mathrm{E}+07$ & $1.60 \mathrm{E}+06$ & & $1.23 \mathrm{E}+00$ & & $1.23 \mathrm{E}+00$ & $\mathrm{~A} 1$ \\
\hline W84 & $9.42 \mathrm{E}+06$ & $3.19 \mathrm{E}+05$ & & $1.23 \mathrm{E}+00$ & & $1.23 \mathrm{E}+00$ & $\mathrm{~A} 1$ \\
\hline W85 & $3.49 \mathrm{E}+09$ & $1.57 \mathrm{E}+06$ & & $9.27 \mathrm{E}+01$ & & $9.27 \mathrm{E}+01$ & A3 \\
\hline W86 & $1.60 \mathrm{E}+07$ & $7.23 \mathrm{E}+05$ & & $9.24 \mathrm{E}-01$ & & $9.24 \mathrm{E}-01$ & $\mathrm{~A} 1$ \\
\hline W87 & $4.68 \mathrm{E}+07$ & $8.64 \mathrm{E}+05$ & & $2.26 \mathrm{E}+00$ & & $2.26 \mathrm{E}+00$ & $\mathrm{~A} 2$ \\
\hline W88 & $1.34 \mathrm{E}+07$ & $4.96 \mathrm{E}+05$ & & $1.13 \mathrm{E}+00$ & & $1.13 \mathrm{E}+00$ & $\mathrm{~A} 1$ \\
\hline W89 & $2.40 \mathrm{E}+07$ & $1.39 \mathrm{E}+06$ & & $7.18 \mathrm{E}-01$ & & $7.18 \mathrm{E}-01$ & $\mathrm{~A} 1$ \\
\hline W90 & $2.29 \mathrm{E}+07$ & $1.55 \mathrm{E}+06$ & & $6.16 \mathrm{E}-01$ & & $6.16 \mathrm{E}-01$ & $\mathrm{~A} 1$ \\
\hline W91 & $1.24 \mathrm{E}+07$ & $8.40 \mathrm{E}+05$ & & $6.16 \mathrm{E}-01$ & & $6.16 \mathrm{E}-01$ & $\mathrm{~A} 1$ \\
\hline W92 & $1.54 \mathrm{E}+08$ & $6.08 \mathrm{E}+05$ & & $1.06 \mathrm{E}+01$ & & $1.06 \mathrm{E}+01$ & $\mathrm{~A} 2$ \\
\hline W93 & $1.08 \mathrm{E}+08$ & $6.75 \mathrm{E}+05$ & & $6.66 \mathrm{E}+00$ & & $6.66 \mathrm{E}+00$ & $\mathrm{~A} 2$ \\
\hline W94 & $4.16 \mathrm{E}+07$ & $5.83 \mathrm{E}+04$ & & $2.97 \mathrm{E}+01$ & & $2.97 \mathrm{E}+01$ & $\mathrm{~A} 2$ \\
\hline W95 & $3.00 \mathrm{E}+07$ & $1.52 \mathrm{E}+06$ & & $8.21 \mathrm{E}-01$ & & $8.21 \mathrm{E}-01$ & $\mathrm{~A} 1$ \\
\hline W96 & $2.42 \mathrm{E}+07$ & $5.79 \mathrm{E}+05$ & & $1.74 \mathrm{E}+00$ & & $1.74 \mathrm{E}+00$ & $\mathrm{~A} 1$ \\
\hline W97 & $9.04 \mathrm{E}+06$ & $7.34 \mathrm{E}+05$ & & $5.13 \mathrm{E}-01$ & & $5.13 \mathrm{E}-01$ & $\mathrm{~A} 1$ \\
\hline W98 & $4.02 \mathrm{E}+09$ & $7.11 \mathrm{E}+05$ & & $2.35 \mathrm{E}+02$ & & $2.35 \mathrm{E}+02$ & A3 \\
\hline W99 & $5.01 \mathrm{E}+07$ & $1.85 \mathrm{E}+06$ & & $1.13 \mathrm{E}+00$ & & $1.13 \mathrm{E}+00$ & $\mathrm{~A} 1$ \\
\hline W100 & $5.48 \mathrm{E}+09$ & $4.96 \mathrm{E}+05$ & & $4.61 \mathrm{E}+02$ & & $4.61 \mathrm{E}+02$ & A3 \\
\hline W101 & $1.42 \mathrm{E}+07$ & $9.59 \mathrm{E}+05$ & & $6.16 \mathrm{E}-01$ & & $6.16 \mathrm{E}-01$ & $\mathrm{~A} 1$ \\
\hline W102 & $4.12 \mathrm{E}+11$ & $5.55 \mathrm{E}+06$ & & $3.09 \mathrm{E}+03$ & & $3.09 \mathrm{E}+03$ & A3 \\
\hline W103 & $2.27 \mathrm{E}+07$ & $1.03 \mathrm{E}+06$ & & $9.24 \mathrm{E}-01$ & & $9.24 \mathrm{E}-01$ & $\mathrm{~A} 1$ \\
\hline W104 & $1.45 \mathrm{E}+10$ & $3.20 \mathrm{E}+06$ & & $1.89 \mathrm{E}+02$ & & $1.89 \mathrm{E}+02$ & A3 \\
\hline W105 & $8.44 \mathrm{E}+09$ & $1.04 \mathrm{E}+06$ & & $3.39 \mathrm{E}+02$ & & $3.39 \mathrm{E}+02$ & A3 \\
\hline
\end{tabular}


Table E.1 (continued)

\begin{tabular}{|c|c|c|c|c|c|c|c|}
\hline Region no. & $\begin{array}{l}\text { Volume } \\
\left(\mathrm{m}^{3}\right)\end{array}$ & $\begin{array}{l}\text { Advection rate } \\
\left(\mathrm{m}^{3} / \mathrm{h}\right)\end{array}$ & $\begin{array}{l}\text { Is there a watershed } \\
\text { after this one }\end{array}$ & $\begin{array}{l}\text { Retention in } \\
\text { watershed (d) }\end{array}$ & $\begin{array}{l}\text { Retention after } \\
\text { watershed }(\mathrm{d})\end{array}$ & $\begin{array}{l}\text { Retention time } \\
\text { until the sea }(\mathrm{d})\end{array}$ & $\begin{array}{l}\text { Archetype watershed } \\
\text { classification }\end{array}$ \\
\hline W106 & $1.85 \mathrm{E}+07$ & $1.25 \mathrm{E}+06$ & & $6.16 \mathrm{E}-01$ & & $6.16 \mathrm{E}-01$ & $\mathrm{~A} 1$ \\
\hline W107 & $1.65 \mathrm{E}+07$ & $4.47 \mathrm{E}+05$ & & $1.54 \mathrm{E}+00$ & & $1.54 \mathrm{E}+00$ & $\mathrm{~A} 1$ \\
\hline W108 & $2.01 \mathrm{E}+07$ & $4.29 \mathrm{E}+05$ & & $1.95 \mathrm{E}+00$ & & $1.95 \mathrm{E}+00$ & $\mathrm{~A} 1$ \\
\hline W109 & $1.59 \mathrm{E}+07$ & $4.04 \mathrm{E}+05$ & & $1.64 \mathrm{E}+00$ & & $1.64 \mathrm{E}+00$ & $\mathrm{~A} 1$ \\
\hline W110 & $1.19 \mathrm{E}+07$ & $2.69 \mathrm{E}+05$ & & $1.85 \mathrm{E}+00$ & & $1.85 \mathrm{E}+00$ & $\mathrm{~A} 1$ \\
\hline W111 & $1.08 \mathrm{E}+08$ & $3.01 \mathrm{E}+05$ & & $1.50 \mathrm{E}+01$ & & $1.50 \mathrm{E}+01$ & $\mathrm{~A} 2$ \\
\hline W112 & $1.27 \mathrm{E}+07$ & $1.03 \mathrm{E}+06$ & & $5.13 \mathrm{E}-01$ & & $5.13 \mathrm{E}-01$ & $\mathrm{~A} 1$ \\
\hline W113 & $2.84 \mathrm{E}+08$ & $6.94 \mathrm{E}+06$ & & $1.71 \mathrm{E}+00$ & & $1.71 \mathrm{E}+00$ & $\mathrm{~A} 1$ \\
\hline W114 & $1.36 \mathrm{E}+08$ & $2.20 \mathrm{E}+06$ & & $2.57 \mathrm{E}+00$ & & $2.57 \mathrm{E}+00$ & A2 \\
\hline W115 & $1.88 \mathrm{E}+11$ & $6.18 \mathrm{E}+05$ & & $1.27 \mathrm{E}+04$ & & $1.27 \mathrm{E}+04$ & A3 \\
\hline W116 & $2.88 \mathrm{E}+11$ & $1.79 \mathrm{E}+06$ & & $6.71 \mathrm{E}+03$ & & $6.71 \mathrm{E}+03$ & A3 \\
\hline W117 & $1.69 \mathrm{E}+11$ & $8.55 \mathrm{E}+05$ & & $8.21 \mathrm{E}+03$ & & $8.21 \mathrm{E}+03$ & A3 \\
\hline W118 & $1.64 \mathrm{E}+07$ & $2.13 E+05$ & & $3.20 \mathrm{E}+00$ & & $3.20 \mathrm{E}+00$ & A2 \\
\hline W119 & $4.87 \mathrm{E}+09$ & $7.42 \mathrm{E}+05$ & & $2.74 \mathrm{E}+02$ & & $2.74 \mathrm{E}+02$ & A3 \\
\hline W120 & $1.44 \mathrm{E}+08$ & $2.25 \mathrm{E}+05$ & & $2.66 \mathrm{E}+01$ & & $2.66 \mathrm{E}+01$ & A2 \\
\hline W121 & $5.92 \mathrm{E}+10$ & $7.79 \mathrm{E}+05$ & & $3.17 \mathrm{E}+03$ & & $3.17 \mathrm{E}+03$ & A3 \\
\hline W122 & $3.23 \mathrm{E}+07$ & $5.34 \mathrm{E}+05$ & & $2.52 \mathrm{E}+00$ & & $2.52 \mathrm{E}+00$ & $\mathrm{~A} 2$ \\
\hline W123 & $7.72 \mathrm{E}+06$ & $5.63 \mathrm{E}+05$ & & $5.72 \mathrm{E}-01$ & & $5.72 \mathrm{E}-01$ & $\mathrm{~A} 1$ \\
\hline W124 & $3.43 \mathrm{E}+08$ & $2.24 \mathrm{E}+06$ & & $6.37 \mathrm{E}+00$ & & $6.37 \mathrm{E}+00$ & A2 \\
\hline W125 & $9.30 \mathrm{E}+06$ & $2.52 \mathrm{E}+05$ & & $1.54 \mathrm{E}+00$ & & $1.54 \mathrm{E}+00$ & $\mathrm{~A} 1$ \\
\hline W126 & $4.62 \mathrm{E}+09$ & $8.42 \mathrm{E}+06$ & W126 & $2.28 \mathrm{E}+01$ & $4.01 \mathrm{E}+02$ & $4.24 \mathrm{E}+02$ & A3 \\
\hline W127 & $7.40 \mathrm{E}+09$ & $2.50 \mathrm{E}+06$ & W127 & $1.23 \mathrm{E}+02$ & $4.01 \mathrm{E}+02$ & $5.24 \mathrm{E}+02$ & A3 \\
\hline W128 & $7.37 \mathrm{E}+09$ & $5.03 \mathrm{E}+06$ & W128 & $6.11 \mathrm{E}+01$ & $4.01 \mathrm{E}+02$ & $4.62 \mathrm{E}+02$ & A3 \\
\hline W129 & $6.24 \mathrm{E}+07$ & $5.03 \mathrm{E}+06$ & & $5.16 \mathrm{E}-01$ & & $5.16 \mathrm{E}-01$ & $\mathrm{~A} 1$ \\
\hline W130 & $1.77 \mathrm{E}+06$ & $3.40 \mathrm{E}+05$ & & $2.17 \mathrm{E}-01$ & & $2.17 \mathrm{E}-01$ & $\mathrm{~A} 1$ \\
\hline W131 & $1.04 \mathrm{E}+07$ & $1.56 \mathrm{E}+03$ & & $2.78 \mathrm{E}+02$ & & $2.78 \mathrm{E}+02$ & A3 \\
\hline W132 & $1.16 \mathrm{E}+08$ & $4.43 \mathrm{E}+05$ & & $1.10 \mathrm{E}+01$ & & $1.10 \mathrm{E}+01$ & $\mathrm{~A} 2$ \\
\hline W133 & $2.39 \mathrm{E}+07$ & $2.36 \mathrm{E}+04$ & & $4.21 \mathrm{E}+01$ & & $4.21 \mathrm{E}+01$ & $\mathrm{~A} 2$ \\
\hline W134 & $1.81 \mathrm{E}+07$ & $4.31 E+05$ & & $1.74 \mathrm{E}+00$ & & $1.74 \mathrm{E}+00$ & $\mathrm{~A} 1$ \\
\hline W135 & $1.44 \mathrm{E}+07$ & $3.39 \mathrm{E}+05$ & & $1.77 \mathrm{E}+00$ & & $1.77 \mathrm{E}+00$ & $\mathrm{~A} 1$ \\
\hline W136 & $4.46 \mathrm{E}+07$ & $1.47 \mathrm{E}+06$ & & $1.26 \mathrm{E}+00$ & & $1.26 \mathrm{E}+00$ & $\mathrm{~A} 1$ \\
\hline
\end{tabular}

\section{References}

FAO. Food balance sheets. Food and Agriculture Organization (FAO); 2001.

Finnveden G, Hauschild MZ, Ekvall T, Guinée J, Heijungs R, Hellweg S, et al. Recent developments in life cycle assessment. J Environ Manage 2009;91:1-21.

Fiot, D., Quels défis ? Quels modèles pour y répondre ? Application d'un modèle économie-environnement-impacts à l'évaluation des impacts environnementaux en Chine induits par l'Europe, et aux taxes carbones aux frontières de l'UE, [PhD thesis]2009, Ecole Nationale Supérieure des mines de Paris; France.

Global Runoff Data Centrehttp://www.bafg.de/GRDC/EN/Home/homepage_node.html, 2002

Hauschild M, Huijbregts M, Jolliet O, MacLeod M, Margni M, Van de Meent D, et al. Building a model based on scientific consensus for life cycle impact assessment of chemicals: the search for harmony and parsimony. Environ Sci Technol 2008;42: 7032-7.

Hellweg S, Demou E, Bruzzi R, Meijer A, Rosenbaum R, Huijbregts M, et al. Integrating human indoor air pollutant exposure within life cycle impact assessment. Environ Sci Technol 2009;43:1670-9.

Henderson AD, Hauschild MZ, van de Meent D, Huijbregts MAJ, Larsen HF, Margni M, et al. USEtox fate and ecotoxicity factors for comparative assessment of toxic emissions in life cycle analysis: sensitivity to key chemical properties. Int J Life Cycle Assess 2011;16:701-9.

Humbert S, Manneh R, Shaked S, Wannaz C, Horvath A, Deschênes L, et al. Assessing regional intake fractions in North America. Sci Total Environ 2009;407: 4812-20.

Humbert S, Marshall JD, Shaked S, Spadaro JV, Nishioka Y, Preiss P, et al. Intake fraction for particulate matter: recommendations for life cycle impact assessment. Environ Sci Technol 2011;45:4808-16.

Jolliet, O.; Wannaz, C.; Fantke, P.; Shaked, S. Multi-scale, multimedia modeling with Pangea local to global human health impacts of emissions in multiple continents. in: Proceedings C., ed. International Conference on Ecobalance. Yokohama, Japan; 2012.

Lehner B, Verdin K, Jarvis A. HydroSHEDS technical documentation; 2006.

Lundie S, Huijbregts M, Rowley H, Mohr N, Feitz A. Australian characterisation factors and normalisation figures for human toxicity and ecotoxicity. J Clean Prod 2007;15: 819-32.

MacLeod M, Bennett D, Perem M, Maddalena R, McKone T, Mackay D. Dependence of intake fraction on release location in a multimedia framework: a case study of four contaminants in North America. J Ind Ecol 2004;8:89-102.

Manneh R, Margni M, Deschênes L. Spatial variability of intake fractions for Canadian emission scenarios: a comparison between three resolution scales. Environ Sci Technol 2010;44:4217-24.

Margni M. Source to intake modeling in like cycle impact assessment. Lausanne, Switzerland: Ecole Polytechnique Fédérale de Lausanne; 2003.
Margni M, Pennington D, Birkved M, Larsen HF, Hauschild MZ. Test set of organic chemicals for life cycle impact assessment characterisation method comparison. OMNIITOX Project Report; 2002.

Margni M, Pennington D, Amman C, Jolliet O. Evaluating multimedia/multipathway model intake fraction estimates using POP emission and monitoring data. Environ Pollut 2004; 128:263-77.

Miller RE, Blair PD. Input-output analysis: foundations and extensions. New Jersey: Prentice-Hall; 1985.

Pennington DW, Potting J, Finnveden G, Lindeijer E, Jolliet O, Rydberg T, et al. Life cycle assessment part 2: current impact assessment practice. Environ Int 2004; 30:721-39.

Pennington DW, Margni M, Ammann C, Jolliet O. Multimedia fate and human intake modeling: spatial versus nonspatial insights for chemical emissions in Western Europe. Environ Sci Technol 2005;39:1119-28.

Peters G, Hertwich EG. The application of multi-regional input-output analysis to industrial ecology: evaluating trans-boundary environmental impacts. In: Suh S, editor. Handbook of input-output analysis for industrial ecology. Dordrecht, The Netherlands: Springer; 2007

Pistocchi A, Zulian G, Vizcaino P, Marinov D. Multimedia assessment of pollutant pathways in the environment, European scale model (MAPPE-Europe) Luxembourg: Office for Official Publications of the European Communities; 2010 [EUR 24256 EN].

Potting J, Hauschild M. Spatial differentiation in life cycle impact assessment: a decade of method development to increase the environmental realism of life cycle impact assessment. Int J Life Cycle Assess 2006;11:11-3.

Rochat D, Margni M, Jolliet O. Continent-specific intake fractions and characterization factors for toxic emissions: does it make a difference? Int J Life Cycle Assess 2004;11: 55-63.

Rosenbaum R, Bachmann T, Gold L, Huijbregts M, Jolliet O, Juraske R, et al. USEtox-the UNEP-SETAC toxicity model: recommended characterisation factors for human toxicity and freshwater ecotoxicity in life cycle impact assessment. Int J Life Cycle Assess 2008;13:532-46

Rosenbaum R, Huijbregts M, Henderson A, Margni M, McKone T, van de Meent D, et al. USEtox human exposure and toxicity factors for comparative assessment of toxic emissions in life cycle analysis: sensitivity to key chemical properties. Int J Life Cycle Assess 2011;16:710-27.

Sedlbauer K, Braune A, Humbert S, Margni M, Schuller O, Fischer M. Spatial differentiation in life cycle assessment: moving forward to more operational sustainability Technikfolgenabschätzung - Theorie und Praxis (Technology assessment), 16. ; 2007. p. 24-31.

Shaked S. Multi-continental multimedia model of pollutant intake and application to impacts of global emissions and globally traded goods [PhD thesis] Ann Arbour: The University of Michigan; 2011. 
Sleeswijk AW, Heijungs R. GLOBOX: a spatially differentiated global fate, intake and effect model for toxicity assessment in LCA. Sci Total Environ 2010;408: 2817-32.

Udo de Haes HA, Finnveden G, Goedkoop M, Hauschild MZ, Hertwich E, Hofstetter P, et al. Life cycle impact assessment: striving towards best practice. Pensacola, United States of America: SETAC Press; 2002.

Vizcaíno P, Pistocchi A. A GIS model-based assessment of the environmental distribution of $\gamma$-hexachlorocyclohexane in European soils and waters. Environ Pollut 2010;158: 3017-27.
Vörösmarty C, Fekete B, Meybeck M, Lammers R. Geomorphometric attributes of the global systemof rivers at 30-minute spatial resolution (STN-30). J Hydrol 2000: 17-39.

Wenger Y, Li D, Jolliet O. Indoor intake fraction considering surface sorption of air organic compounds for life cycle assessment. Int J Life Cycle Assess 2012;17: 919-31. 